\title{
Title: Religion and Prosociality across the Globe
}

Authors: Felipe Valencia Caicedo ${ }^{1 * \dagger}$, Thomas Dohmen ${ }^{2 * \dagger}$, Andreas Pondorfer ${ }^{3 * \dagger}$

Affiliations:

$5 \quad{ }^{1}$ University of British Columbia, Vancouver School of Economics, IZA and CEPR

$6 \quad{ }^{2}$ University of Bonn, IZA Institute of Labor Economics, and University of Maastricht

$7 \quad{ }^{3}$ Technical University of Munich, TUMCS for Biotechnology and Sustainability

8 *Correspondence to: felipe.valencia@ubc.ca,t.dohmen@uni-bonn.de and

9 andreas.pondorfer@tum.de.

$10 \uparrow$ All authors contributed equally. Authors are arranged alphabetically.

\section{Summary:}

13 In this paper we analyze newly available, globally representative data on preferences and world 14 religions (Christianity, Islam, Hinduism, Buddhism and Judaism). We find that individuals who 15 report believing in such religions also exhibit more prosocial preferences, as measured by their

16 levels of positive reciprocity, altruism and trust. We further document heterogeneous patterns of 17 negative reciprocity and punishment across world religions. The association between religion and 18 prosocial preferences is stronger in more populous societies and weaker in countries with better 19 institutions. The interactive results between these variables point towards a substitution effect 20 between religious and secular institutions, when it comes to prosocial preferences. 
Introduction

23 Religion constitutes a fundamental aspect of culture and has a long pedigree in social science

24 research. Sigmund Freud viewed religion as "the most precious possession of culture" and culture

25 "what make[s] our communal existence possible" 1. Max Weber argued that religion shapes society

26 and economic behavior by affecting preferences for hard-work and thrift ${ }^{2}$. In The Elementary

27 Forms of the Religious Life French sociologist Émile Durkheim went even further, to conclude

28 that religion and society are one ${ }^{3}$. Though social scientists have spent considerable research efforts

29 to study the nexus of religion, culture and behavior, some important unanswered questions remain,

30 such as the role of religion for social cooperation. To make progress on this fundamental question,

31 we focus here on the relationship between world religions and social preferences across the globe.

33 In particular, we provide novel insights about the relationship between social preferences and 34 religion, by showing that believers in world religions across the globe are more prosocial, as 35 measured by positive reciprocity, altruism and trust, compared to individuals not affiliated with 36 world religions. This positive effect is present for Christians, Muslims, Hindus, Buddhists and 37 Jews. We also find significant heterogeneity in terms of negative reciprocity and punishment 38 patterns across world religions, which are central tenets of religious beliefs ${ }^{4,5}$ and key elements of 39 human cooperative norms ${ }^{6}$. Christians, Muslims and Hindus exhibit lower levels of negative 40 reciprocity, including second- and third-party punishments, results emerge insignificant for 41 Buddhists, and are significantly positive for Jews and in line with the rules of life of these 42 respective religions, such as the Torah's "law of retaliation" 7. These results suggest that 43 individuals internalize social values extolled and propagated by their religion, thus shaping 44 individuals' reciprocity, altruism and trust. 
45 We focus our analysis on social preferences, in terms of trust, altruism, positive and negative 46 reciprocity, as they are key motives sustaining social cooperation. Positive reciprocity and negative

47 reciprocity capture the predisposition to cooperate conditionally on other's cooperation and to 48 punish violations of cooperative norms even at a net cost to the punisher ${ }^{8}$ and have been argued 49 to be evolutionary stable strategies ${ }^{9}$. Positive reciprocity fosters altruistic behavior and 50 cooperation ${ }^{10}$. Altruistic punishments and sanctioning institutions promote cooperative behavior 51 among non-kin, a central puzzle in human behavior ${ }^{11,12}$. Similarly, trust has been linked to 52 cooperation ${ }^{13}$, and although this view is contested ${ }^{14}$, social trust is held to be "an important 53 lubricant of a social system" 15 and a crucial component of social capital ${ }^{16}$. Given the importance 54 of these social preferences for human cooperation, we contribute by providing stylized facts on their relationship with religion, based on experimentally validated measures in representative 56 population samples across the globe.

58 Our findings speak to the longstanding hypothesis that religions promote prosocial behavior ${ }^{17}$. 59 Empirical studies have documented a positive relationship between religion and human 60 cooperation with non-kin, inside and outside the lab (summarized in ${ }^{18}$ ). Recent studies have found 61 that Christianity weakened traditional kinship ties and led to the emergence of Western, Educated, 62 Industrialized, Rich and Democratic (WEIRD) societies, which are characterized by more 63 individualistic, independent, and impersonally prosocial behavior ${ }^{19,20}$. Others have documented 64 the particular importance of moralizing gods and religious beliefs in supernatural monitoring for 65 cooperation and the observance of moral norms ${ }^{21-23}$. Empirical evidence also shows that the share 66 of people who believe in hell negatively predicts crime rates, while the relationship is positive for 67 people who believe in heaven ${ }^{24}$. Religion has been linked to cooperation and prosociality in 
specific societies, such as Mauritius, Paraguay and the Democratic Republic of Congo (DRC) ${ }^{25-}$

6927 . We contribute to this literature with new globally representative and experimentally validated 70 data, on all world religions, covering $90 \%$ of human population and global gross domestic product 71 (GDP).

73 Importantly, we explore the relationship between religion and prosocial preferences with respect 74 to population size. From a psychological and cultural evolutionary standpoint, previous literature $75^{28-30}$ hypothesize that religious beliefs might have been particularly important to sustain human cooperation in expanding societies. This is entirely consistent with the collective action problem 77 growing larger as populations expand. Though tantalizing, this hypothesis enjoys limited quantitative support and has not yet been tested systematically at a global scale. We show that the relationship between organized religions and prosocial behavior is indeed more marked in countries with larger populations, as previously hypothesized, and tested later here.

82 Extending the analysis to institutions, which have also been shown to contribute to successfully 83 organizing human societies (see, among others, ${ }^{31-33}$ ), we find that the effect of religion on 84 prosocial preferences is stronger in places where state institutions are weaker, pointing towards a 85 substitution effect between religion and institutions in the social organization of human societies, 86 in line with David Hume's idea that morality does not need to be based on divine authority but that 87 conventions of justice, i.e. institutions, can foster social cooperation on larger scale ${ }^{34}$. These 88 findings speak to the literature on the interplay between culture and institutions ${ }^{35}$ and the potential 89 substitution between religion and institutions ${ }^{30,36}$. Finally, interacting religion with both 90 population size and institutional quality, we find stronger effects in larger populations coupled 
91 with weaker effects in countries with better institutions, thus confirming the substitutability

92 between religion and institutions in the social organization of human societies.

By highlighting the role of religion for social preferences, we contribute to an important literature on the determinants of preferences that has documented the effect of age, gender and cognitive

96 skills on preferences ${ }^{37-39}$. In line with this literature, we employ econometric specifications with 97 individual level controls, including math skills and income, as well as country specific fixed 98 effects, though our results are robust to alternative specifications (as detailed in the supplementary 99 information). In terms of magnitudes, we find that the size of the religion coefficient is twice as 100 large as the one for gender. Overall, we find that religion plays a fundamental role in shaping social 101 preferences, hinting at its importance in sustaining human cooperation.

\section{Data and method}

104 To empirically analyze the relationship between religious affiliation and social preferences, we 105 use the Global Preference Survey (GPS) ${ }^{37,38,40}$. The GPS was collected as part of the Gallup World 106 Poll 2012 and contains data on experimentally and observationally validated measures of six 107 fundamental preferences with regards to social and nonsocial domains: willingness to take risks; 108 patience; altruism; trust ${ }^{1}$; positive and negative reciprocity, which capture the willingness to 109 reward kind actions or to punish unkind actions at one's own personal costs, respectively. The

\footnotetext{
${ }^{1}$ We note that trust is not a preference but a composite trait, including beliefs about others' behavior, prosocial preferences, and preferences for risk-taking. Given its importance, however, we decided to include it in our analysis. In this paper, we focus the analysis on prosociality, hence we do not analyze here the relationship with risk and patience.
} 
110 GPS data meets three critical conditions for our empirical analysis: i) reliability of preference

111 measures, which have been experimentally validated ii) extensive cultural variation with

112 comprehensive global coverage, including all world religions and iii) representativeness of country

113 samples (for details on the preference survey module and its experimental validation, see ${ }^{41}$ ). The

114 GPS was implemented in a total of 76 countries, representing $90 \%$ of the global population and

115 global GDP. To provide geographic representativeness as well as developmental and cultural

116 variation, countries were selected to include all continents and a wide range of economic

117 development levels. For each country, the data contain samples representative of the resident

118 population aged 15 and older, with a median sample size of 1,000 participants per country. In total,

119 the data include preference measures for about 80,000 participants (see supplementary information

120 for further details on the data collection and construction of the social preferences).

121 The GPS data allow for the assessment of the existence and quantification of differences in 122 preferences between members of world religions and non-religious people at the global level. To 123 identify members of world religions (i.e., Christian, Muslim, Hinduism, Buddhism and Judaism) 124 and non-religious people, we use the religious affiliation variable (self-reported) from the Gallup 125 World Poll 2012. Data on religious affiliation is available for 71 countries and for about 75,500 126 participants (see supplementary information and Table S1 for summary statistics of religious 127 affiliation across countries). ${ }^{2}$ To examine the relationship with population and institutions we use 128 additional data sets. Total population size is taken from the World Bank Development Indicators

\footnotetext{
${ }^{2}$ In our analysis we use data on social preferences from 75 countries. Since the World Gallup Poll did not ask for religious affiliation in Saudi Arabia, Jordan, United Arab Emirates and Egypt in 2012, we classified all respondents from these countries as Muslims. Our findings are robust to the exclusion of these four countries (see supplementary information for details on the statistical analysis).
} 
129 dataset (see https://databank.worldbank.org/source/world-development-indicators). The measure

130 of institutional quality is taken from the Polity IV project (see https://www.systemicpeace.org).

131 To analyze differences in preferences between members of world religions and non-religious

132 people and for ease of interpretation, we first standardized each preference measure at the global

133 level to exhibit a mean of 0 and a standard deviation of 1 . Next, for each preference we performed

134 individual ordinary least-squares (OLS) regressions on the global sample using as independent 135 variable a religion indicator in which non-religious people are the reference group. The obtained 136 coefficient on the religion indicator serves as the measure of the difference between members of 137 world religions and non-religious people for a given preference. We follow the same method when 138 we look at specific world religions. We also used median splits for population and institutional 139 quality. We performed individual OLS regressions for each sample separately and tested if the 140 obtained coefficients for the religion indicator are statistically significantly different from each 141 other (see supplementary information for details on the statistical analyses).

142 We also included several controls to isolate the effect of religion from potentially confounding 143 factors that might differ between religious and non-religious people. These control variables are 144 gender, age, age squared, subjective math skills, education level and household income, though 145 results also hold unconditionally and with exogenous controls (i.e., gender and age) only. To 146 capture time-invariant characteristics at the country level, we included country fixed effects, 147 though our main results are also robust to using subnational region fixed effects. Standard errors 148 were clustered at the country level. 


\section{Results: Empirical relationship between religious affiliation and social preferences}

151 Fig. 1A plots the coefficient of the religion indicator for negative reciprocity, positive reciprocity, 152 altruism and trust. Given the standardization, the estimated coefficients of the religion indicator 153 can be interpreted as the standard deviation change in the dependent variable. Members of world 154 religions have statistically significantly higher levels of trust (coef. $0.114, \mathrm{P}<0.001$ ) and altruism 155 (coef. $0.145, \mathrm{P}<0.001$ ) compared to non-religious people. Negative reciprocity is statistically 156 significantly different between members of world religions and non-religious people (coef. -0.092 , $157 \mathrm{P}<0.001$ ), while differences in positive reciprocity are statistically indistinguishable from zero 158 (coef. 0.006, $\mathrm{P}=0.785$ ). These findings confirm that religion has a significant effect on the variation 159 in human psychology, in line with the literature surveyed.

160 To benchmark the magnitude of the differences in preference between members of world religions

161 and non-religious people, we compare the size of the estimated coefficient of the religion indicator 162 with the size of the estimated coefficient for gender (see for example, ${ }^{38,42}$ ). Fig. S5 in the 163 supplementary information compares the effect size of gender and religion. The estimated 164 coefficients of religion and gender follow similar patterns with two main findings standing out: i) 165 the estimated coefficients are statistically significantly different compared to the reference group 166 (non-religious, and males, respectively) except for religion and positive reciprocity and ii) the 167 estimated coefficients of religion are larger (smaller) in size for altruism and trust (for negative 168 and positive reciprocity) compared to the estimated coefficients of gender. These findings show 169 that religion is a relevant factor in explaining differences in preferences, in addition to gender and 170 other determinants.

171 Fig. 1B shows the differences in social preferences across Christians, Muslims, Hindus, Buddhists 172 and Jews. We used a principal component analysis (PCA) to summarize positive reciprocity, 
173 altruism and trust. The (first) predicted principal component then served as the summary index of

174 prosocial preferences or prosociality (see supplementary information for details on the statistical

175 analysis and for an empirical and theoretical discussion of the social preference index). Christians,

176 Muslims, Hindus, Buddhists and Jews exhibit statistically significantly higher levels of

177 prosociality compared to non-religious people. The range of the differences in standard deviations

178 varies between 0.138 and 0.252 ( $\mathrm{P}<0.001$ across all world religions). Differences in social

179 preferences between world religions only exist for Christians and Muslims. Muslims have higher

180 levels of prosociality compared to Christians (coef. $|0.098|, \mathrm{P}<0.0001){ }^{3}$ These results remain

181 unchanged if we use PCA to summarize two alternative versions of the prosocial preference index

182 that are based on i) altruism and trust and ii) negative reciprocity, positive reciprocity, altruism

183 and trust (see Tab. S5). Interestingly, in terms of heterogeneous effects by gender, the effect

184 observed is larger for women than for men (see Fig. S6).

185 Fig. 1C shows differences in punishment patterns across world religions. The measure of negative 186 reciprocity is decomposed into its three components: second-party punishment (2PP), third-party 187 punishment (3PP) and negative reciprocity without punishment (see supplementary information 188 for details on survey items and construction of preferences). Christians, Muslims and Hindus have 189 statistically significantly lower levels of second-party and third-party punishment compared to 190 non-religious people (for Christianity: coef. $-0.095, \mathrm{P}<0.001$ in $2 \mathrm{PP}$ and coef. $-0.084, \mathrm{P}<0.001$ in 191 3PP; for Islam: coef. $-0.100, \mathrm{P}<0.05$ in $2 \mathrm{PP}$ and coef. $-0.117, \mathrm{P}<0.01$ in $3 \mathrm{PP}$; for Hinduism: coef. $192-0.161, \mathrm{P}<0.01$ in $2 \mathrm{PP}$ and coef. $-0.178, \mathrm{P}<0.001$ in $3 \mathrm{PP})$. There are no statistically significant 193 differences between Buddhists and non-religious people. Jews have statistically significantly

\footnotetext{
${ }^{3}$ We test the null hypothesis that coefficients of the categorical variable identifying a religion are equal to each other. The differences between coefficients are reported as absolute differences.
} 
194 higher levels of third-party punishment compared to non-religious people (coef. $0.231, \mathrm{P}<0.001$ ) 195 and members of other world religions (for Christianity: coef. $|0.315|, \mathrm{P}<0.001$; for Islam: coef. $196|0.348|, \mathrm{P}<0.001$; for Hinduism: coef. $|0.409|, \mathrm{P}<0.001$; for Buddhism: coef. $|0.214|, \mathrm{P}<0.01)$. This 197 last finding is driven by Jews inside Israel (see Fig. S7 and supplementary analysis).

198 To test whether our main findings in Fig. 1A to C are robust to potential confounders, we apply 199 several robustness checks. First, we run two alternative specifications where we exclude standard 200 controls. In the first specification we exclude all individual controls and keep only country fixed 201 effects. In the second specification we include only exogenous individual controls (i.e., gender, 202 age, age-squared) and country fixed effects. Results from these alternative specifications 203 confirmed our main findings (see Tab. S3 for Fig. 1A; Tab. S5 for Fig. 1B; Tab. S9 for Fig. 1C). 204 Second, we also control for the importance of religiosity (see for example, ${ }^{43}$ ) in our analysis. 205 People with higher religiosity are on average more prosocial compared to people with lower 206 religiosity (see Fig. 8A and B). Our main results on the differences in prosociality between 207 religious and non-religious people remain essentially unchanged (see Table S4 for Fig. 1A; Tab. 208 S6 for Fig. 1B; Tab. S10 for Fig. 1C). Third, our findings are robust to specifications where we 209 exclude four countries for which religious affiliation was not available (see Tab. S4 for Fig. 1A; 210 Tab. S7 for Fig. 1B, Tab. S10 for Fig. 1C). Finally, to control for potential confounders that may 211 occur due to variation within countries, we replicate our main specifications with subnational 212 region fixed effects instead of country fixed effects. All of our main findings remain unchanged 213 (see Tab. S17 for Fig. 1A, and Tab. S18 for Fig. 1B and C).

214 Fig. 2A compares prosociality between members of world religions living in countries with small 215 population size (below median) and members of world religions living in countries with large 216 population size (above median). Two main results from this analysis stand out. First, religious 
217 people have statistically significantly higher levels of prosociality compared to non-religious

218 people across both categories (for small population size: coef. 0.094, $\mathrm{P}<0.05$, for large population

219 size, coef. 0.197, $\mathrm{P}<0.001$ ). Second, members of world religions in countries with large population

220 size have significantly higher levels of social preferences compared to religious people in countries

221 with small population size (coef. $|0.103|, \mathrm{P}<0.05$ ). This result is in line with the fact that the

222 collective action problem becomes more salient in larger populations and that world religions are

223 one critical factor that may have contributed to the emergence and sustainability of large groups.

224 Fig. 2B compares prosociality between members of world religions living in countries with low

225 (below the median) institutional quality and members of world religions living in countries with

226 high (above the median) institutional quality. As before, two main results from this median split

227 stand out. First, religious people are statistically significantly more prosocial compared to non-

228 religious people across the two categories (for low institutional quality: coef. $0.251, \mathrm{P}<0.001$, for

229 high institutional quality: coef. $0.132, \mathrm{P}<0.001)$. Second, members of world religions in countries

230 with low institutional quality have statistically significantly higher levels of social preferences

231 compared to religious people in countries with high institutional quality (coef. $|0.120|, \mathrm{P}<0.05$ ). In

232 Fig. S9 we compare the effect size of world religion and institutional quality on negative

233 reciprocity, positive reciprocity, altruism and trust. The magnitudes of the estimated coefficients

234 of religion and institutional quality are of considerable size and follow opposite directions, positive

235 for religion and negative for institutions. These findings suggest a substitution effect between

236 religion and institutions in terms of prosociality, as previously hypothesized.

237 The findings in Fig. 2A and B are robust to specifications without standard controls and with

238 exogenous individual controls only (see Tab. S11 for Fig. 2A and Tab. S13 for Fig. 2B). Results

239 remain also unchanged when we add the kinship intensity index as control variable to our main 
240 specification (see Tab. S15 for Fig. 2A and 2B). Moreover, the results are robust to specifications

241 using different values for institutional quality and population size (see Tab. S12 for Fig. 2A; Tab.

242 S14 for Fig. 2B) and excluding countries with incomplete data for the measure of institutional

243 quality (see Tab. S14 for Fig. 2B). Likewise, the results are essentially unchanged when we

244 exclude four countries for which data on religious affiliation was not available from the sample

245 (see Tab. S12 for Fig. 2A; Tab. S14 for Fig. 2B).

246 Finally, Fig. 3 shows the relationship between the interaction of population size and institutional 247 quality and religion. Using the median split, we performed individual OLS regressions for each of 248 the following four groups: Low Institutional Quality and Small Population Size (LIQ-SP), Low 249 Institutional Quality and Large Population Size (LIQ-LP), High Institutional Quality and Small 250 Population Size (HIQ-SP) and High Institutional Quality and Large Population Size (HIQ-LP).

251 Subsequently, we tested if the obtained coefficients for the religion indicator are statistically 252 significantly different across these four groups (see supplementary information for details on the 253 statistical analysis). We find first that institutional quality matters "more" in countries with large 254 population size. The difference between LIQ-LP and HIQ-LP is statistically significantly different 255 (coef. $|0.123|, \mathrm{P}<0.01$ ). Second, population size has a larger effect in high institutional quality 256 countries: The difference between HIQ-SP and HIQ-LP is marginally different (coef. |0.092|, $257 \mathrm{P}=0.055)$. The heterogeneous effects point again towards a substitutability between religious and 258 secular institutions, when it comes to prosociality. ${ }^{4}$

\footnotetext{
${ }^{4}$ The main findings in Fig. 3 are robust to using specifications without standard controls and with exogenous individual controls only (see Tab. S16, and Tab. S17, respectively).
} 


\section{Conclusion}

261 In this article we show the importance of religion in shaping prosocial preferences. We find 262 stronger effects on prosociality in countries with larger populations and weaker institutions, 263 suggesting a substitution effect between religion and institutions in the social organization of 264 societies. The patterns are also consistent with the nature of the collective action problem, which 265 grows in larger populations. We also find lower levels of negative reciprocity, second- and third266 party punishments, for Christians, Muslims and Hindus, and higher for Jews. We see value in these 267 results, given the tight link between prosocial preferences and human cooperation, as well as the 268 global prevalence and deep-roots of religious beliefs. We are not able to fully distinguish here 269 between religion and cooperation, acknowledging that these processes might be co-evolutionary

$270 \quad\left(\right.$ see $\left.^{44-46}\right)$. Future research could further disentangle this relationship, as well as explore the link 271 between religion and other facets of human psychology and behavior, such as patience and 272 attitudes towards risk. 


\section{References and Notes:}

275 1. Freud, S. The future of an illusion. (Broadview Press, 2012).

276 2. Weber, M. The Protestant ethic and the" spirit" of capitalism and other writings.

277 (Penguin, 2002).

278 3. Durkheim, E. The Elementary Forms of the Religious Life. (Macmillan, 1915).

279 4. Laurin, K., Shariff, A. F., Henrich, J. \& Kay, A. C. Outsourcing punishment to God:

280 Beliefs in divine control reduce earthly punishment. Proc. R. Soc. B Biol. Sci. 279, 3272$281 \quad 3281(2012)$.

282 5. Johnson, D. God is watching you: How the fear of God makes us human. (Oxford 283 University Press, USA, 2016).

284 6. Herrmann, B., Thöni, C. \& Gächter, S. Antisocial punishment across societies. Science 285 286 (80-. ). 319, 1362-1367 (2008).

7. Sosis, R. \& Ruffle, B. J. Religious ritual and cooperation: Testing for a relationship on Israeli religious and secular kibbutzim. Curr. Anthropol. 44, 713-722 (2003).

8. Fehr, E. \& Gintis, H. Human motivation and social cooperation: Experimental and analytical foundations. Annu. Rev. Sociol. 33, 43-64 (2007).

9. Gintis, H., Bowles, S., Boyd, R. \& Fehr, E. Explaining altruistic behavior in humans. Evol. Hum. Behav. (2003) doi:10.1016/S1090-5138(02)00157-5.

10. Fehr, E. \& Fischbacher, U. The nature of human altruism. Nature 425, 785-791 (2003).

11. Fehr, E. \& Gächter, S. Altruistic punishment in humans. Nature 415, 137-140 (2002).

12. Gürerk, Ö., Irlenbusch, B. \& Rockenbach, B. The competitive advantage of sanctioning institutions. Science (80-. ). 312, 108-111 (2006).

300 15. Arrow, K. J. The limits of organization. (WW Norton \& Company, 1974).

301 16. Putnam, R. D. Bowling alone: America's declining social capital. in Culture and politics 302 223-234 (Springer, 2000).

303 17. Norenzayan, A. \& Shariff, A. F. The origin and evolution of religious prosociality. Science (80-. ). 322, 58-62 (2008). 
305 18. Iyer, S. The new economics of religion. J. Econ. Lit. 54, 395-411 (2016).

306 19. Schulz, J. F., Bahrami-Rad, D., Beauchamp, J. P. \& Henrich, J. The Church, intensive

307 kinship, and global psychological variation. Science (80-. ). 366, (2019).

308 20. Henrich, J. The weirdest people in the world: How the west became psychologically

309 peculiar and particularly prosperous. (Farrar, Straus and Giroux, 2020).

310 21. Atkinson, Q. D. \& Bourrat, P. Beliefs about God, the afterlife and morality support the 311 role of supernatural policing in human cooperation. Evol. Hum. Behav. 32, 41-49 (2011).

312 22. Purzycki, B. G. et al. Moralistic gods, supernatural punishment and the expansion of 313 human sociality. Nature 530, 327-330 (2016).

314 23. Lang, M. et al. Moralizing gods, impartiality and religious parochialism across 15

$315 \quad$ societies. Proc. R. Soc. B 286, 20190202 (2019).

316 24. Shariff, A. F. \& Rhemtulla, M. Divergent effects of beliefs in heaven and hell on national 317 crime rates. PLoS One 7, (2012).

318 25. Xygalatas, D. et al. Big Gods in small places: the Random Allocation Game in Mauritius. 319 Relig. Brain Behav. 8, 243-261 (2018).

320 26. Bergeron, A. Religion and the Scope of Morality: Evidence from Exposure to Missions in 321 the DRC. (2019).

322 27. Valencia Caicedo, F. The mission: Human capital transmission, economic persistence, and 323 culture in South America. Q. J. Econ. 134, 507-556 (2019).

28. Norenzayan, A. \& Shariff, A. F. The origin and evolution of religious prosociality.

326 29. Norenzayan, A. Big gods: How religion transformed cooperation and conflict. (Princeton $327 \quad$ University Press, 2013).

328 30. Norenzayan, A. et al. The cultural evolution of prosocial religions. Behav. Brain Sci. 39, $329 \quad$ (2016)

330 31. North, D. C. A transaction cost theory of politics. J. Theor. Polit. 2, 355-367 (1990).

331 32. Acemoglu, D., Johnson, S. \& Robinson, J. A. The colonial origins of comparative 332 development: An empirical investigation. Am. Econ. Rev. 91, 1369-1401 (2001).

333 33. Henrich, J. et al. Markets, religion, community size, and the evolution of fairness and 334 punishment. Science (80-. ). (2010) doi:10.1126/science.1182238.

335 34. Hume, D. A treatise of human nature. (Courier Corporation, 2003). 
35. Alesina, A. \& Giuliano, P. Culture and institutions. J. Econ. Lit. 53, 898-944 (2015).

337 36. Lowes, S., Nunn, N., Robinson, J. A. \& Weigel, J. L. The Evolution of Culture and

338 Institutions: Evidence From the Kuba Kingdom. Econometrica (2017) doi:10.3982/ecta14139.

340 37. Falk, A. et al. Global evidence on economic preferences. Q. J. Econ. (2018) doi:10.1093/qje/qjy013.

342 38. Falk, A. \& Hermle, J. Relationship of gender differences in preferences to economic 343

39. Baldassarri, D. \& Abascal, M. Diversity and prosocial behavior. Science (80-. ). 369, 1183-1187 (2020).

40. World Gallup Poll. https://www.gallup.com/analytics/318875/global-research.aspx.

41. Falk, A., Becker, A., Dohmen, T. J., Huffman, D. \& Sunde, U. The Preference Survey Module: A Validated Instrument for Measuring Risk, Time, and Social Preferences. SSRN Electronic Journal (2016) doi:10.2139/ssrn.2725874.

42. Croson, R. \& Gneezy, U. Gender differences in preferences. J. Econ. Lit. 47, 448-474 (2009).

43. Galen, L. W. Does religious belief promote prosociality? A critical examination. Psychol.

45. Beheim, B. et al. Corrected analyses show that moralizing gods precede complex societies

44. Whitehouse, H. et al. Complex societies precede moralizing gods throughout world history. Nature 568, 226-229 (2019). but serious data concerns remain. (2019).

46. Enke, B. Kinship, cooperation, and the evolution of moral systems. Q. J. Econ. 134, 9531019 (2019).

47. Falk, A. \& Hermle, J. Relationship of gender differences in preferences to economic development and gender equality. Science (80-. ). 362, (2018).

48. Berg, J., Dickhaut, J. \& McCabe, K. Trust, reciprocity, and social history. Games Econ. Behav. (1995) doi:10.1006/game.1995.1027.

49. Selten, R. Die Strategiemethode zur Erforschung des eingeschränkt rationalen Verhaltens im Rahmen eines Oligopolexperiments, S. 136-168. in Beiträge zur experimentellen Wirtschafts-Forschung. Tübingen: JCB Mohr (ed. Sauermann, H.) 136-168 (Mohr, 1967). 
367 50. Güth, W., Schmittberger, R. \& Schwarze, B. An experimental analysis of ultimatum 368 bargaining. J. Econ. Behav. Organ. 3, 367-388 (1982).

369 51. Falk, A., Fehr, E. \& Fischbacher, U. Driving forces behind informal sanctions.

$370 \quad$ Econometrica 73, 2017-2030 (2005).

371 52. Fehr, E. \& Fischbacher, U. Why social preferences matter - The impact of non-selfish

372 motives on competition, cooperation and incentives. Econ. J. (2002) doi:10.1111/1468$373 \quad 0297.00027$.

374 53. Altmann, S., Dohmen, T. \& Wibral, M. Do the reciprocal trust less? Econ. Lett. (2008)

375 doi:10.1016/j.econlet.2007.09.012.

376

377 
379 Acknowledgments: We thank Benedict Herrmann, Mukesh Eswaran, Armin Falk, Ara

380 Norenzayan, Joseph Henrich, and Patrick Francois, and Jonathan Schulz for helpful comments that

381 greatly improved the manuscript.

382 Funding: We did not receive specific funding to conduct this study. During the study, F.V.C was 383 supported by the University of British Columbia, T.D. acknowledges funding by the Deutsche 384 Forschungsgemeinschaft (DFG, German Research Foundation) through CRC TR 224 (Project A01 385 and under Germany's Excellence Strategy - EXC 2126/1-390838866. A.P. was supported by the 386 University of Bonn and Technical University of Munich.

387 Ethics: The data we used are publicly available and cannot be used to identify individuals.

388 Author contributions: All authors contributed equally to this work. Authors are arranged 389 alphabetically.

390 Competing interests: We, the authors, declare that we have no financial conflicts of interest in 391 relation to the content of this article.

392 Data and materials availability: The data on preferences are deposited at https://www.briq393 institute.org/global-preferences/downloads. The preference data can be matched with the 394 religious data from Gallup Poll via the unique Gallup ID. 
(A) Religion and Social Preferences

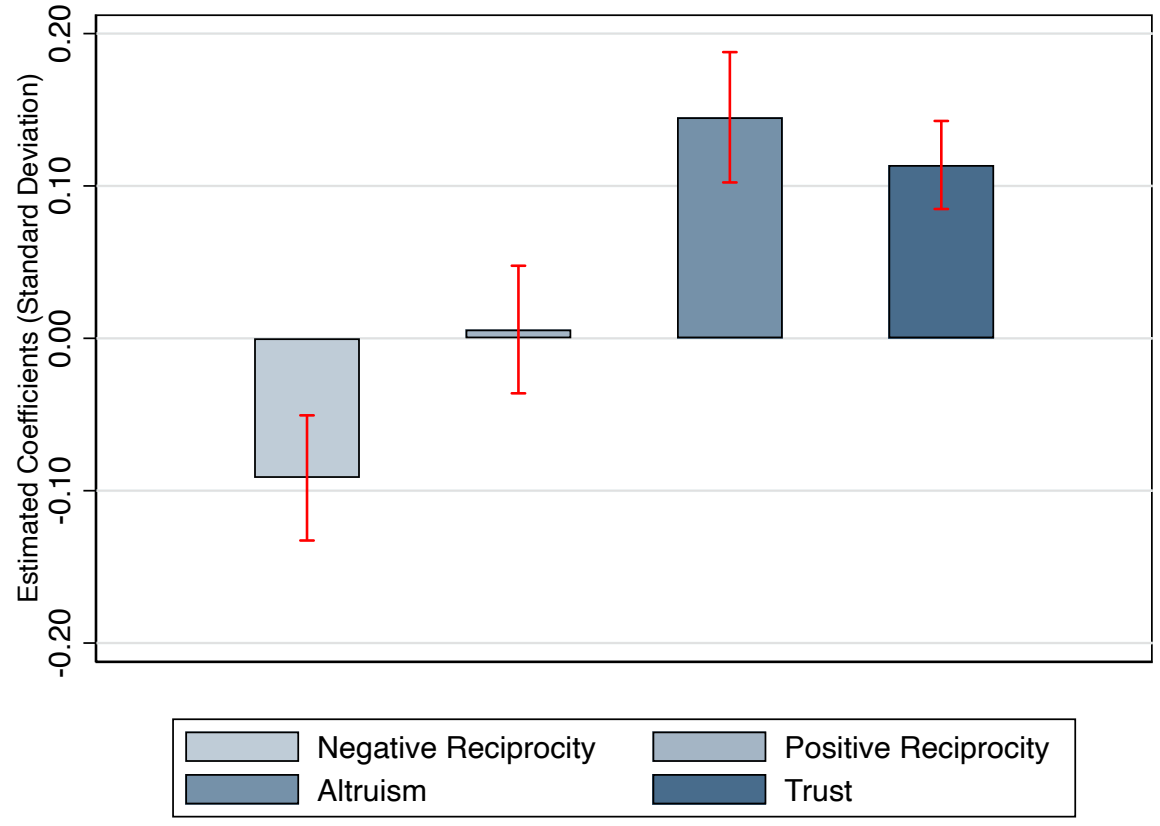

(B) Prosocial Preference Index Across World Religions

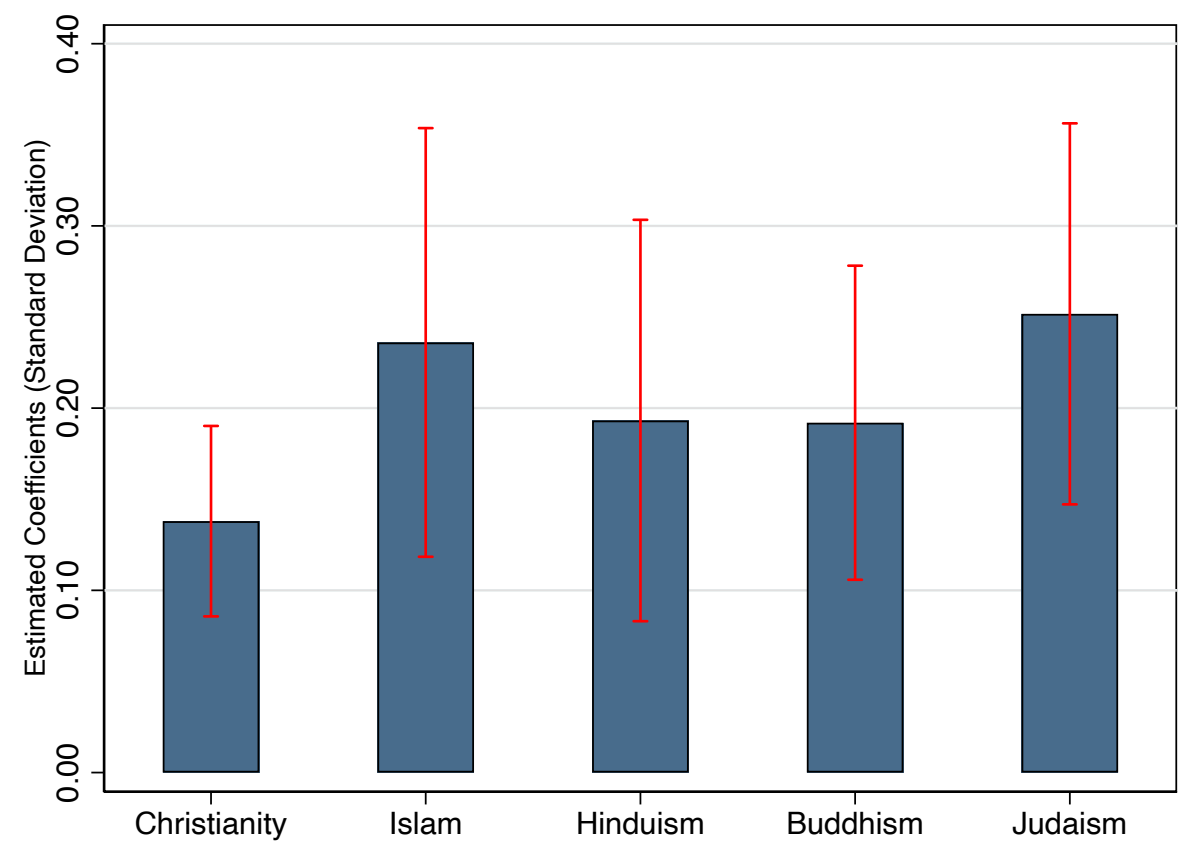




\section{(C) Punishment Patterns Across World Religions}

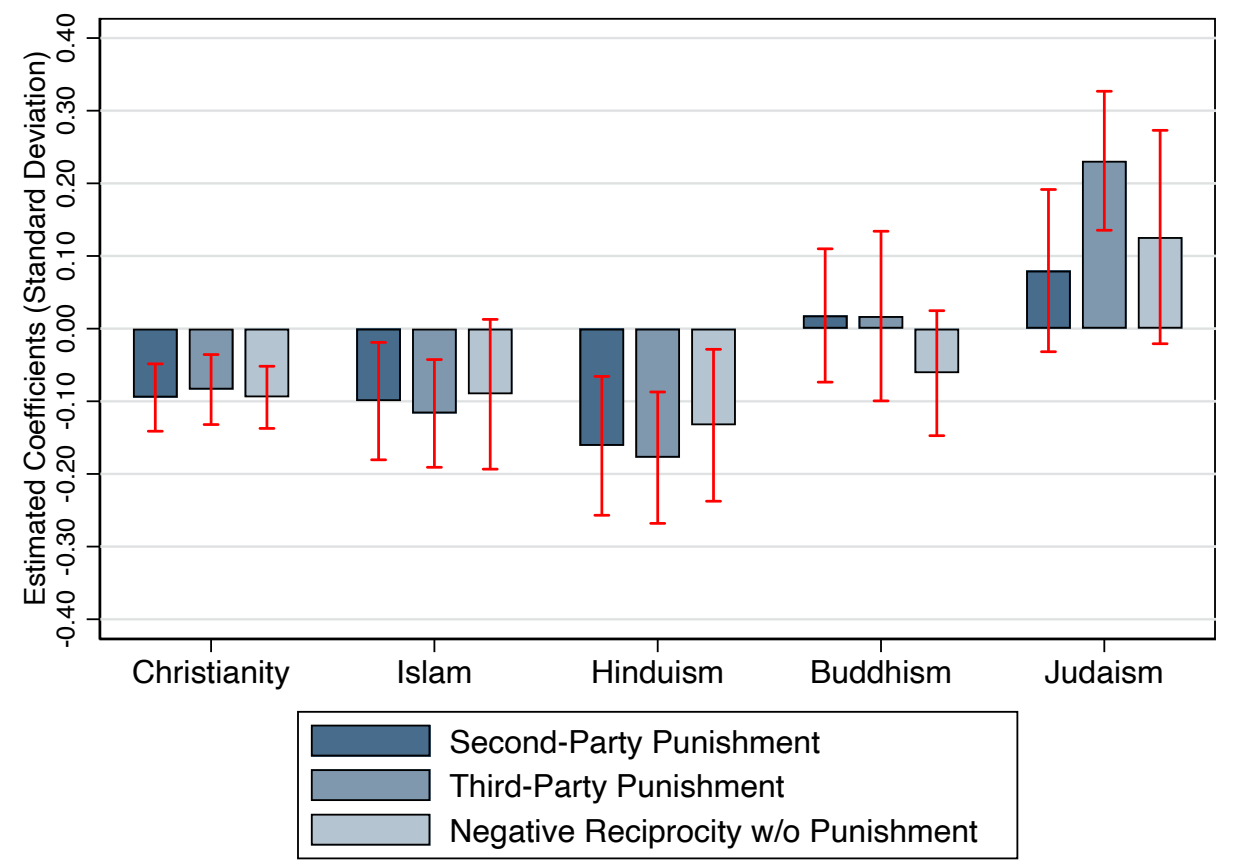

Fig. 1. Differences in social preferences between members of world religions and nonreligious people.

399 (A) The figure plots coefficients based on an OLS regression (see also Tab. S2). Positive values indicate that members of world religions exhibited higher levels of the respective preference, negative values indicate that members of world religions exhibited lower levels of the respective preference. For each preference, the difference between members of world religions and non-religious people was calculated as the coefficient on a categorical variable that takes on the value 0 if the respondent is nonreligious (reference group), 1 if the respondent is part of a world religion (i.e., Christian, Muslim, Hinduism, Buddhism and Judaism) and 2 if the respondent belongs to a non-world religion (results not shown). Specifications include the following control variables: gender, age, age squared, subjective math skills, education level, household income, and country fixed effects (negative reciprocity: $\mathrm{n}=$ 72,888; positive reciprocity: $n=74,070$; altruism: $n=73,854$; trust: $n=73,140$ ). Error bars indicate $95 \%$ confidence intervals obtained from standard errors clustered at the country level ( $\mathrm{n}=75$ countries). (B) The figure plots coefficients based on an OLS regression (see also Tab. S5). The summary index of prosocial preferences is based on a principal component analysis of positive reciprocity, altruism and trust. Positive values indicate that members of world religions exhibited higher levels of social preferences, negative values indicate that members of world religions exhibited lower levels of prosocial preferences. The difference between members of world religions and non-religious people was calculated as the coefficient on a categorical variable that takes on the value 0 if the respondent is non-religious (reference group), 1 if the respondent is Christian, 2 if the respondent is Muslim, 3 if the 
417 respondent is Hindu, 4 if the respondent is Buddhist, 5 if the respondent is Jewish and 6 if the 418 respondent belongs to a non-world religion (results not shown). Specifications include the following 419 control variables: gender, age, age squared, subjective math skills, education level, household income, 420 and country fixed effects $(n=72,888)$. Error bars indicate $95 \%$ confidence intervals obtained from 421 standard errors clustered at the country level( $\mathrm{n}=75$ countries).

422 (C) The figure plots coefficients based on an OLS regression (see also Tab. S8). Punishment patterns 423 are obtained by decomposing the measure of negative reciprocity into its three components: second424 party punishment, third-party punishment and negative reciprocity without punishment. Positive 425 values indicate that members of world religions exhibited higher levels of the respective preference, 426 negative values indicate that members of world religions exhibited lower levels of the respective 427 preference. The difference between members of world religions and non-religious people was 428 calculated as the coefficient on a categorical variable that takes on the value 0 if the respondent is non429 religious (reference group), 1 if the respondent is Christian, 2 if the respondent is Muslim, 3 if 430 respondent is Hindu, 4 if respondent is Buddhist, 5 if respondent is Jewish and 6 if respondent belongs 431 to a non-world religion (results not shown). Specifications include the following control variables: 432 gender, age, age squared, subjective math skills, education level, household income, and country fixed 433 effects (second-party punishment: $n=72,946$; third-party punishment: $n=72,946$; negative reciprocity 434 w/o punishment: $n=72,888)$. Error bars indicate $95 \%$ confidence intervals obtained from standard 435 errors clustered at the country level ( $n=75$ countries). 
(A) Religion and Population Size

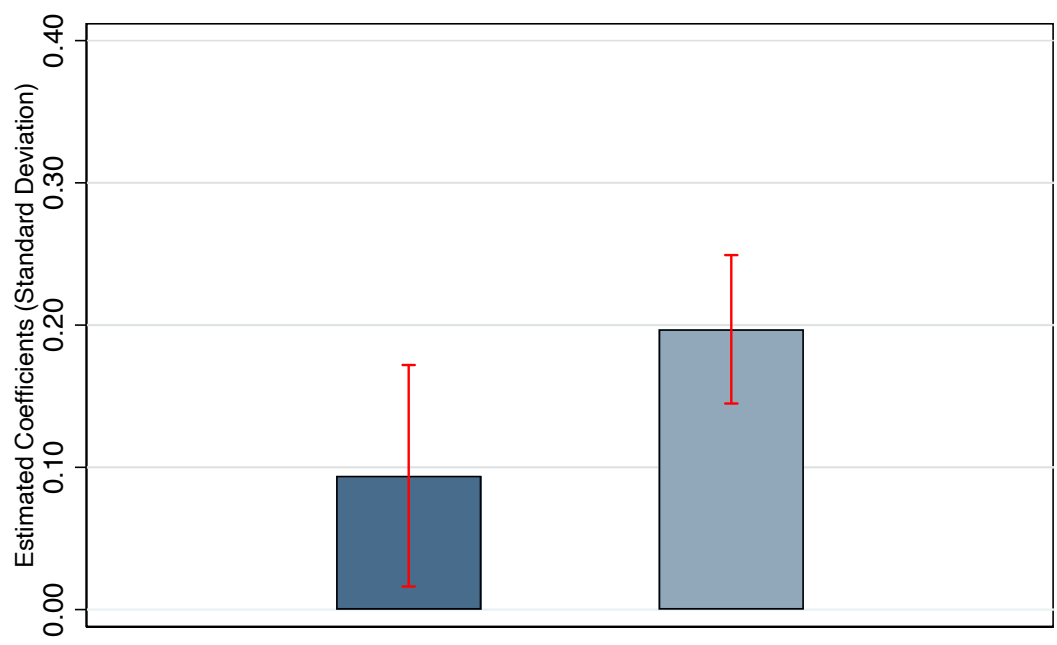

Small Population Size

Large Population Size

(B) Religion and Institutional Quality

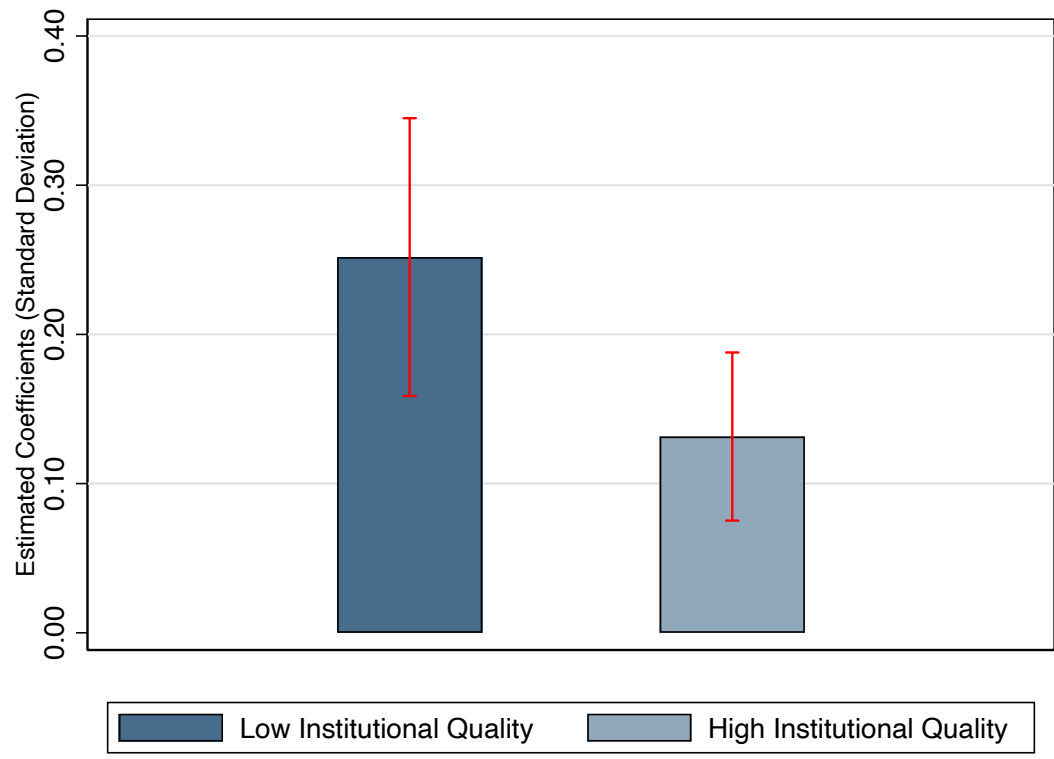

438 Fig. 2. The impact of population size and institutions on differences in prosocial preferences 439 between members of world religions and non-religious people.

440 (A) The figure plots coefficients based on an OLS regression (see also Tab. S11). The sample was split 441 into respondents living in countries with small population size (below median) and respondents living 442 in countries with large population size (above median). The summary index of prosocial preferences 
443 is based on a principal component analysis of positive reciprocity, altruism and trust. Positive values

444 indicate that members of world religions exhibited higher levels of prosocial preferences, negative 445 values indicate that members of world religions exhibited lower levels of social preferences. The 446 difference between members of world religions and non-religious people was calculated as the 447 coefficient on a categorical variable that takes on the value 0 if the respondent is non-religious 448 (reference group), 1 if the respondent is part of a world religion (i.e., Christian, Muslim, Hinduism, 449 Buddhism and Judaism) and 2 if the respondent belongs to a non-world religion (results not shown). 450 Specifications include the following control variables: gender, age, age squared, subjective math skills, 451 education level, household income, and country fixed effects (small population size: $n=37,468$; large 452 population size: $n=35,420$ ). Error bars indicate $95 \%$ confidence intervals obtained from standard errors 453 clustered at the country level (small population size: $n=41$ countries; large population size: $n=34$ 454 countries).

455 (B) The figure plots coefficients based on an OLS regression (see also Tab. S13). Same as in (A) but 456 the sample was split into respondents living in countries with low institutional quality (below median) 457 and respondents living in countries with high institutional quality (above median). Specifications 458 include the following control variables: gender, age, age squared, subjective math skills, education 459 level, household income, and country fixed effects (low institutional quality: n=34,049; high 460 institutional quality: $\mathrm{n}=38,839)$. Error bars indicate $95 \%$ confidence intervals obtained from standard 461 errors clustered at the country level (low institutional quality: $n=35$ countries; high institutional quality: $462 \mathrm{n}=40$ countries). 


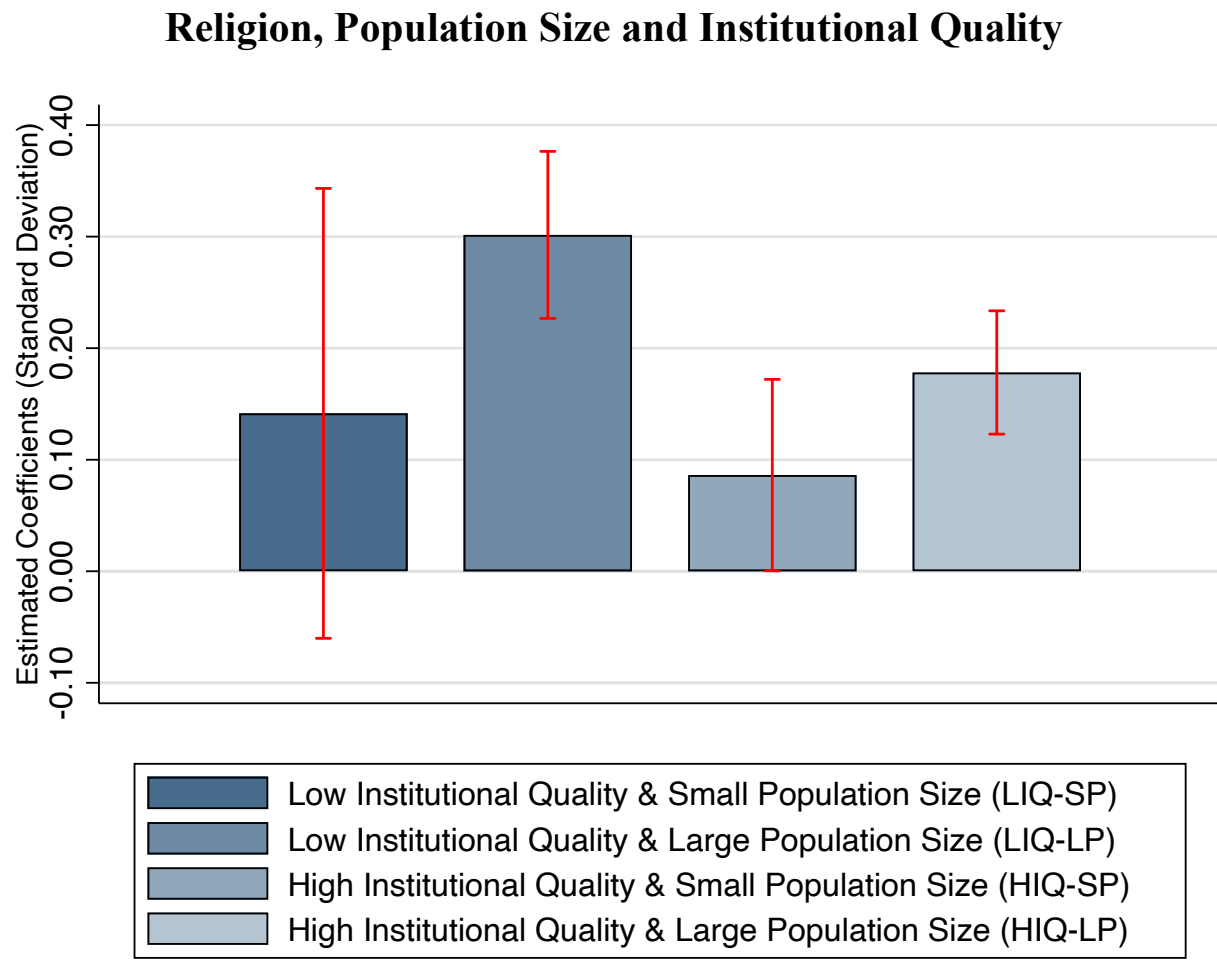

Fig. 3. The impact of the interactive effect of population size and institutions on differences

\section{in prosocial preferences between members of world religions and non-religious people.}

The figure plots coefficients based on an OLS regression (see Tab. S16 and Tab. S17, respectively). The sample was split into the following four categories: i) LIQ-SP: respondents living in countries with low institutional quality and small population size, ii) LIQ-LP: respondents living in countries with low institutional quality and large population size, iii) HIQ-SP: respondents living in countries with high institutional quality and small population size, and iv) HIQ-LP respondents living in countries with high institutional quality and large population size. The summary index of prosocial preferences is based on a principal component analysis of positive reciprocity, altruism and trust. Positive values indicate that members of world religions exhibited higher levels of prosocial preferences, negative values indicate that members of world religions exhibited lower levels of social preferences. The difference between members of world religions and non-religious people was calculated as the coefficient on a categorical variable that takes on the value 0 if respondent is nonreligious (reference group), 1 if the respondent is part of a world religion (i.e., Christian, Muslim, Hinduism, Buddhism and Judaism) and 2 if respondent belongs to a non-world religion (results not shown). Specifications include the following control variables: gender, age, age squared, subjective math skills, education level, household income, and country fixed effects (LIQ-SP: $n=16,325$; LIQLP: $n=17,724$; HIQ-SP: $n=21,1143$; HIQ-LP: $n=17,696)$. Error bars indicate $95 \%$ confidence intervals obtained from standard errors clustered at the country level (LIQ-SP: $n=18$ countries; LIQ-LP: $n=17$ countries; HIQ-SP: $\mathrm{n}=23$ countries; HIQ-LP: $\mathrm{n}=17$ countries). 


\section{SUPLEMENTARY INFORMATION}

\section{Religion and Prosociality across the Globe}

Authors: Felipe Valencia Caicedo ${ }^{1 * \dagger}$, Thomas Dohmen ${ }^{2 * \dagger}$ Andreas $^{\text {Pondorfer }}{ }^{3 * \dagger}$

7 Affiliations:

$8{ }^{1}$ University of British Columbia, Vancouver School of Economics, IZA and CEPR

9 2University of Bonn, IZA Institute of Labor Economics, and University of Maastricht

$10{ }^{3}$ Technical University of Munich, TUMCS for Biotechnology and Sustainability

11

$12 *$ Correspondence to: felipe.valencia@ubc.ca, t.dohmen@uni-bonn.de and

13 andreas.pondorfer@tum.de.

14

$15 \uparrow$ All authors contributed equally. Authors are arranged alphabetically.

16 


\section{Contents}

Methods and Materials

Overview

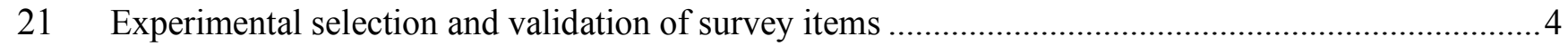

22 Wording of survey items and construction of preference measures ............................................ 6

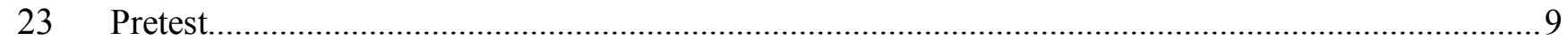

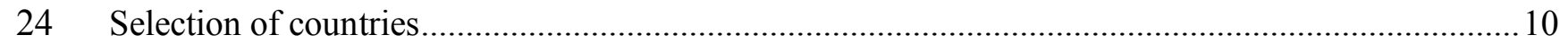

25 Survey item translation and cross-country adjustment of monetary amounts ................................ 13

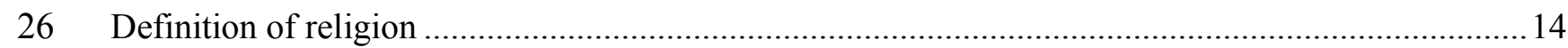

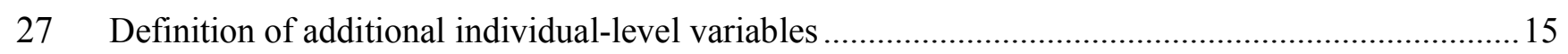

28 Definition of institutional quality and population size variables (including sources) ....................... 15

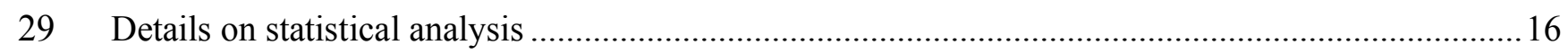

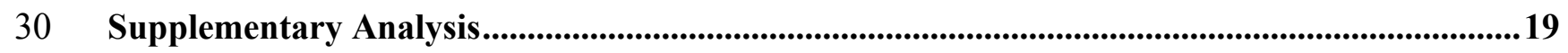

\section{Figures}

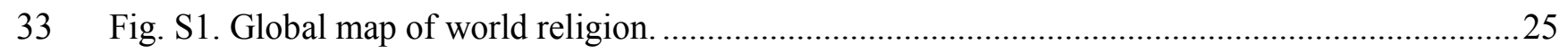

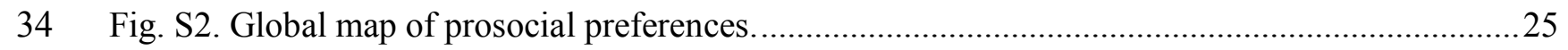

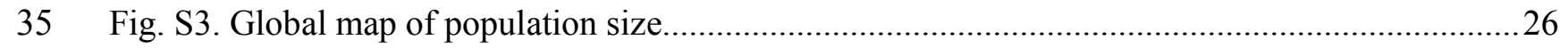

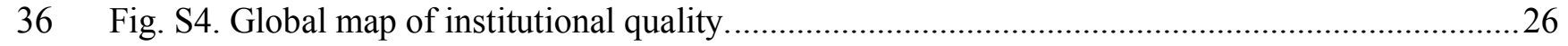

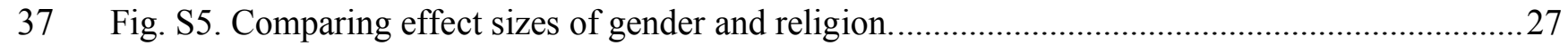

38 Fig. S6. Heterogeneous effects of religion by gender on prosocial preferences...............................28

39 Fig. S7. Punishment patterns of Jewish Israelis and Jews living outside Israel. ..............................29

40 Fig. S8. The heterogeneous effect of religion on prosocial preferences by religiosity.......................31

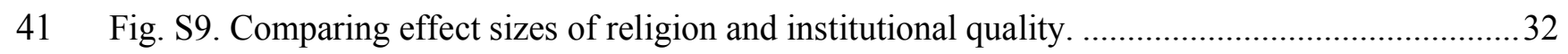

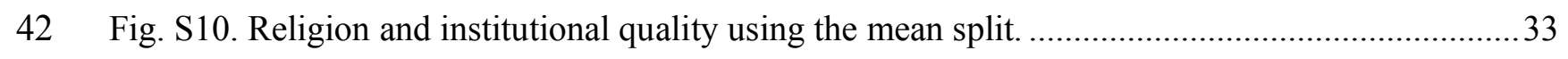

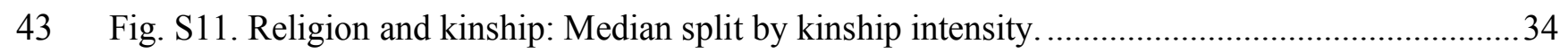

\section{Tables}

46 Tab S1. Summary statistics of religion, population size and institutional quality broken down by

48 Tab. S2. Differences in social preferences between religious and non-religious people. Main results.

50 Tab. S3. Differences in social preferences between religious and non-religious people. Alternative 
52 Tab. S4. Differences in social preferences between religious and non-religious people. Excluding

53 countries from the sample and controlling for religiosity.

54 Tab. S5. Differences in prosocial preferences across world religions. Main results, alternative

55 specifications and alternative measures of the prosocial preference index.

56 Tab. S6. Differences in prosocial preferences across world religions. Controlling for religiosity.......51

57 Tab. S7. Differences in prosocial preferences across world religions. Excluding countries from the

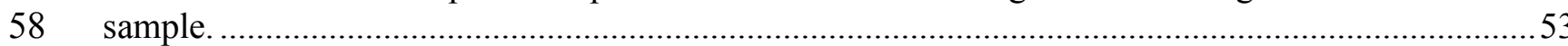

59 Tab. S8. Punishment patterns across world religions. Main results. .............................................55

60 Tab. S9. Punishment patterns across world religions. Alternative specifications. ............................57

61 Tab. S10. Punishment patterns across world religions. Excluding countries from the sample and

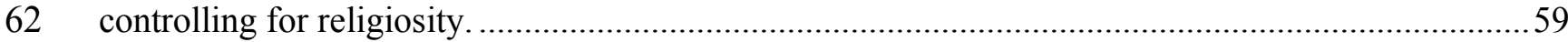

63 Tab. S11. Religion and population size. Main results and alternative specifications.......................60

64 Tab. S12. Religion and population size. Alternative measures of the prosocial preference index,

65 excluding countries from the sample and alternative measures of population size.

66 Tab. S13. Religion and institutional quality. Main results and alternative specifications.

67 Tab. S14. Religion and institutional quality. Alternative measures of the prosocial preference index,

68 excluding countries from the sample and alternative measures of institutional quality. ....................64

69 Tab. S15. Religion, population size and institutional quality. Controlling for kinship intensity. .......66

70 Tab. S16. The impact of the interactive effect of institutional quality and population size on religion.

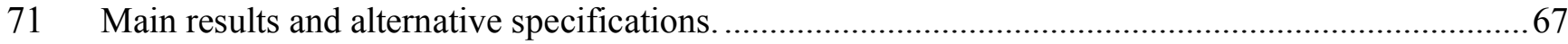

72 Tab. S17. Wald tests of equality of coefficients corresponding to Tab. S16................................68

73 Tab. S18. Differences in social preferences between religious and non-religious people. Controlling

74 for subnational region fixed effects.

75 Tab. S19. Differences in prosocial preferences and punishment across world religions. Controlling 


\section{Methods and Materials}

\section{Overview}

82 The following section contains details on the Global Preference Survey (GPS) data collection on 83 altruism, trust, positive reciprocity and negative reciprocity. The GPS was conducted as part of the 84 Gallup World Poll 2012 through the infrastructure of Gallup. Prior to implementing the GPS, a total 85 of 12 survey items were selected through an ex-ante experimental validation. The survey items were 86 then translated and made internationally comparable. At the end of 2011, a pre-test of the survey items 87 was conducted in 22 countries as part of the Gallup World Poll 2012 pretest. After receiving feedback, 88 minor adjustments were made to the survey items. The GPS was then implemented in a total of 76 89 countries as part of the Gallup World Poll 2012. For further details on the experimental validation and

90 data collection see ${ }^{40,41}$. The individual-level data on preferences are publicly available and can be 91 found here: https://www.briq-institute.org/global-preferences/downloads. The description of the 92 materials and methods related to the GPS in the following paragraphs can be also found in ${ }^{37,47}$.

\section{Experimental selection and validation of survey items}

95 The experimental selection and validation of survey items through laboratory experiments took 96 place at the Laboratory for Experimental Economics at the University of Bonn during the winter 97 2010/2011. 402 subjects took part in incentivized laboratory experiments and answered survey 98 questions for each of the six preferences. The survey questions which performed as the best joint 99 predictors of incentivized behavior were selected as items for the respective preference in the GPS. 100 The following paragraphs contain further details on the experimental validation. 
102 Choice experiments, social preference measures, and survey items in the validation

103 The following section describes the set of incentivized choice experiments and the experimental 104 measures related to social preferences. ${ }^{1}$ An overview table is presented below.

105 In order to isolate social preferences from repeated game motives, all experiments with social 106 interactions were one-shot. Following a perfect stranger random matching protocol, it was ensured that 107 subjects never interacted more than once with the same person.

108 Trust and positive reciprocity were elicited as first and second mover behavior in two investment 109 games ${ }^{48}$ where the amount sent was either doubled or tripled. Hence, each subject took part in four 110 investment games, twice as first mover, twice as second mover. The contingent response method ${ }^{49}$ 111 was applied for second mover behavior. The average of choices as first or second mover served as 112 experimental measures of trust and reciprocity, respectively.

113 Altruism was elicited as donation amount in a dictator game with a charitable organization as 114 recipient. Negative reciprocity was elicited through two different experiments: a subject's minimum 115 acceptable offer in an ultimatum game ${ }^{50}$ and a subject's investment into punishment after unilateral 116 defection of their opponent in a prisoner's dilemma ${ }^{51}$. Both choices were standardized to account for 117 differences in response scales and averaged to obtain the experimental measure of negative reciprocity.

118 The choice experiments were accompanied by a large set of qualitative and quantitative survey 119 items. Goal of the experimental validation was to select those survey items for the GPS which were 120 the best predictors of incentivized behavior in the choice experiments. Candidate survey items were 121 taken from existing surveys, others were newly designed for the experimental selection and validation. 122 The full list of survey items can be found in ${ }^{41}$.

\footnotetext{
${ }^{1}$ Note that the GPS collected data on six preferences: risk, patience, negative reciprocity, positive reciprocity, altruism and trust. Since the focus of this study is on social preferences, we do not describe the survey items related to risk and patience. For a detailed description of all six preferences see Falk et al. ${ }^{37}$.
} 


\begin{tabular}{lll}
\hline Social Preference & Experiment & Measure \\
\hline Trust & $\begin{array}{l}\text { First mover behavior in two } \\
\text { investment games }\end{array}$ & $\begin{array}{l}\text { Average amount sent as a first } \\
\text { mover in both investment games }\end{array}$ \\
\hline Altruism & $\begin{array}{l}\text { First mover behavior in a } \\
\text { dictator game with a charitable } \\
\text { organization as recipient }\end{array}$ & Amount of donation \\
\hline Positive Reciprocity & $\begin{array}{l}\text { Second mover behavior in two } \\
\text { investment games (contingent } \\
\text { response method) }\end{array}$ & $\begin{array}{l}\text { Average amount sent back in both } \\
\text { investment games }\end{array}$ \\
\hline Negative Reciprocity & $\begin{array}{l}\text { Investment into punishment } \\
\text { after unilateral defection of the } \\
\text { opponent in a prisoner's } \\
\text { dilemma (contingent response } \\
\text { method) and minimum } \\
\text { acceptable offer in an } \\
\text { ultimatum game }\end{array}$ & $\begin{array}{l}\text { Average score: amount invested } \\
\text { into punishment and minimum } \\
\text { acceptable offer in an ultimatum } \\
\text { game }\end{array}$ \\
\hline \hline
\end{tabular}

126 Selection of survey items

127 For each preference, the survey items were selected as the best joint predictors of incentivized

128 behavior. Each experimental preference measure was regressed via OLS on different combinations of 129 the survey items. The best combination in terms of explanatory power, measured by adjusted R130 squared, was then identified and selected for the international survey.

\section{Wording of survey items and construction of preference measures}

\section{Survey items}

134 Following the experimental validation, a set of 8 survey items was selected for measuring social 135 preference with the GPS. For each preference, the exact wording of the corresponding survey items is 136 given below. As indicated below, survey items were either qualitative or quantitative. 
"Willingness to act" survey items indicate the following introduction "We now ask for your

139 willingness to act in a certain way in four different areas. Please indicate again your answer on a scale

140 from 0 to 10, where 0 means you are "completely unwilling to do so" and a 10 means you are "very

141 willing to do so". You can also use any numbers between 0 and 10 to indicate where you fall on the

142 scale, like, $0,1,2,3,4,5,6,7,8,9,10 . "$

143 Likewise, "Self-assessment" survey items were preceded by the following introduction: "How 144 well do the following statements describe you as a person? Please indicate your answer on a scale from 0 to 10. A 0 means "does not describe me at all" and a 10 means "describes me perfectly". You 146 can also use any numbers between 0 and 10 to indicate where you fall on the scale, like 0, 1, 2, 3, 4, $147 \quad 5,6,7,8,9,10 . ”$

\section{Positive Reciprocity}

1. Self-assessment (qualitative): "When someone does me a favor I am willing to return it."

2. Choice (quantitative): "Please think about what you would do in the following situation. You are in an area you are not familiar with, and you realize you lost your way. You ask a stranger for directions. The stranger offers to take you to your destination. Helping you costs the stranger about 20 Euro in total. However, the stranger says he or she does not want any money from you. You have six presents with you. The cheapest present costs 5 Euro, the most expensive one costs 30 Euro. Do you give one of the presents to the stranger as a "thankyou"- gift? If so, which present do you give to the stranger? No present / The present worth 5 / 10 / 15 / 20 / 25 / 30 Euro." 
3. Self-assessment (qualitative): "If I am treated very unjustly, I will take revenge at the first occasion, even if there is a cost to do so." In the study we also use the term "negative reciprocity without punishment' for this item.

4. Willingness to act (qualitative): "How willing are you to punish someone who treats you unfairly, even if there may be costs for you?" In the study we also use the term 'second-party punishment' for this item.

5. Willingness to act (qualitative): "How willing are you to punish someone who treats others unfairly, even if there may be costs for you?" In the study we also use the term "third-party punishment' for this item.

III. Altruism

6. Choice (quantitative): "Imagine the following situation: Today you unexpectedly received 1,000 Euro. How much of this amount would you donate to a good cause? (Values between 0 and 1000 are allowed.)"

7. Willingness to act (qualitative): "How willing are you to give to good causes without expecting anything in return?" 
Preference measures

To create the individual-level preference measures the following procedure was employed. First,

188 for each of the 8 survey items z-scores were computed at the individual level. Second, for each

189 preference the respective z-scores were averaged using weights developed in the experimental

190 validation. Technically, these weights were computed as coefficients in OLS regressions of observed

191 choices in the experimental validation on the respective survey items, restricting the sum of coefficients

192 to one. Weights are given by:

193

$\begin{aligned} \text { Positive reciprocity }= & \begin{array}{l}0.4847038 \times \text { Willingness to return favor }+0.5152962 \times \text { Size of } \\ \text { gift }\end{array}\end{aligned}$

Negative reciprocity $=0.6261938 / 2 \times$ Willingness to punish if oneself is treated unfairly $+0.6261938 / 2 \times$ Willingness to punish if other is treated unfairly $+0.3738062 \times$ Willingness to take revenge

195 As explained in the context of the global pre-test (see below), the original survey item for negative

196 reciprocity was split up into two items: the first asking for the willingness to punish if oneself was

197 treated unfairly and the second asking for the willingness to punish if someone was treated unfairly.

198 To apply the weighting procedure from the experimental validation, the corresponding weight was

199 divided by two and applied to the two new modified items.

\section{Pretest}

The global survey was pre-tested in the Gallup World Poll 2012 pre-test, conducted at the end of

203 2011. The pre-test was conducted in 22 countries, including 10 countries in central Asia (Armenia, 204 Azerbaijan, Belarus, Georgia, Kazakhstan, Kyrgyzstan, Russia, Tajikistan, Turkmenistan, Uzbekistan) 
2 countries in South-East Asia (Bangladesh and Cambodia), 5 countries in Southern and Eastern

206 Europe (Croatia, Hungary, Poland, Romania, Turkey), 4 countries in the Middle East and North Africa

207 (Algeria, Jordan, Lebanon, and Saudi-Arabia), and 1 country in Eastern Africa (Kenya) with country208 sample sizes between 10 and 15 respondents. The goal of the pretest was to receive feedback on 209 whether survey items were understandable and/or whether there were cultural differences in the 210 interpretation of survey items. Pre-test respondents were instructed to indicate difficulties in 211 understanding the survey items and were invited to offer suggestions for rewording.

With regards to the quantitative items, no respondent had any problem in understanding the 213 wording and probabilities used in the survey items. With regards to qualitative items, most respondents 214 understood the survey items when being asked to rephrase the respective item in their own words. 215 Some few respondents made suggestions for rewording of the items which led to an adjustment of four 216 items compared to the original (experimentally validated) items.

217 1. In some Eastern European and Central Asian countries, the word "charity" was not well understood and hence replaced by "good cause."

2. Some respondents asked for clarification with regards to the item about one's willingness to punish unfair behavior. As a consequence, this item was split up into two items, one asking for one's willingness to punish unfair behavior towards others, the other for one's willingness to punish unfair behavior towards oneself.

In addition, the format of the survey questions was made consistent with the Gallup World Poll questionnaire style. objective of the selection process was to include all geographic regions and development levels. 229 Additionally, the selection aimed at maximizing variation along country characteristics such as 230 language, historical and political conditions, and ecological features. Furthermore, the selection 
231 process aimed to include non-neighboring and culturally distinct countries. The following tables list

232 the sampled countries (including abbreviations), sample sizes for each country, and interview modes.

\begin{tabular}{|c|c|c|c|}
\hline Abbreviation & Country & Sample Size & Interview Mode \\
\hline $\mathrm{AFG}$ & Afghanistan & 1000 & Face-to-Face \\
\hline ARE & $\begin{array}{l}\text { United Arab } \\
\text { Emirates }\end{array}$ & 1000 & Face-to-Face \\
\hline ARG & Argentina & 1000 & Face-to-Face \\
\hline AUS & Australia & 1002 & Landline/Cellular Phone \\
\hline AUT & Austria & 1001 & Landline/Cellular Phone \\
\hline BGD & Bangladesh & 999 & Face-to-Face \\
\hline $\mathrm{BIH}$ & $\begin{array}{l}\text { Bosnia and } \\
\text { Herzegovina }\end{array}$ & 1004 & Face-to-Face \\
\hline BOL & Bolivia & 998 & Face-to-Face \\
\hline BRA & Brazil & 1003 & Face-to-Face \\
\hline BWA & Botswana & 1000 & Face-to-Face \\
\hline CAN & Canada & 1001 & Landline/Cellular Phone \\
\hline $\mathrm{CHE}$ & Switzerland & 1000 & Landline/Cellular Phone \\
\hline CHL & Chile & 1003 & Face-to-Face \\
\hline $\mathrm{CHN}$ & China & 2574 & $\begin{array}{l}\text { Face-to-Face, Landline } \\
\text { Phone }\end{array}$ \\
\hline CMR & Cameroon & 1000 & Face-to-Face \\
\hline $\mathrm{COL}$ & Colombia & 1000 & Face-to-Face \\
\hline CRI & Costa Rica & 1000 & Face-to-Face \\
\hline $\mathrm{CZE}$ & Czech Republic & 1005 & Face-to-Face \\
\hline DEU & Germany & 997 & Landline/Cellular Phone \\
\hline DZA & Algeria & 1022 & Face-to-Face \\
\hline EGY & Egypt & 1020 & Face-to-Face \\
\hline ESP & Spain & 1000 & Landline/Cellular Phone \\
\hline EST & Estonia & 1004 & Face-to-Face \\
\hline FIN & Finland & 1000 & Landline/Cellular Phone \\
\hline FRA & France & 1001 & Landline/Cellular Phone \\
\hline GBR & United Kingdom & 1030 & Landline/Cellular Phone \\
\hline GEO & Georgia & 1000 & Face-to-Face \\
\hline GHA & Ghana & 1000 & Face-to-Face \\
\hline GRC & Greece & 1000 & Face-to-Face \\
\hline GTM & Guatemala & 1000 & Face-to-Face \\
\hline HRV & Croatia & 992 & Face-to-Face \\
\hline HTI & Haiti & 504 & Face-to-Face \\
\hline HUN & Hungary & 1004 & Face-to-Face \\
\hline IDN & Indonesia & 1000 & Face-to-Face \\
\hline IND & India & 2539 & Face-to-Face \\
\hline IRN & Iran & 2507 & Landline/Cellular Phone \\
\hline IRQ & Iraq & 1000 & Face-to-Face \\
\hline ISR & Israel & 999 & Face-to-Face \\
\hline
\end{tabular}




\begin{tabular}{|c|c|c|c|}
\hline Abbreviation & Country & Sample Size & Interview Mode \\
\hline ITA & Italy & 1004 & Landline/Cellular Phone \\
\hline JOR & Jordan & 1000 & Face-to-Face \\
\hline JPN & Japan & 1000 & Landline Phone \\
\hline $\mathrm{KAZ}$ & Kazakhstan & 999 & Face-to-Face \\
\hline KEN & Kenya & 1000 & Face-to-Face \\
\hline KHM & Cambodia & 1000 & Face-to-Face \\
\hline KOR & South Korea & 1000 & Landline/Cellular Phone \\
\hline LKA & Sri Lanka & 1000 & Face-to-Face \\
\hline LTU & Lithuania & 999 & Face-to-Face \\
\hline MAR & Morocco & 1000 & Face-to-Face \\
\hline MDA & Moldova & 1000 & Face-to-Face \\
\hline MEX & Mexico & 1000 & Face-to-Face \\
\hline MWI & Malawi & 1000 & Face-to-Face \\
\hline NGA & Nigeria & 1000 & Face-to-Face \\
\hline NIC & Nicaragua & 1000 & Face-to-Face \\
\hline NLD & Netherlands & 1000 & Landline/Cellular Phone \\
\hline PAK & Pakistan & 1004 & Face-to-Face \\
\hline PER & Peru & 1000 & Face-to-Face \\
\hline PHL & Philippines & 1000 & Face-to-Face \\
\hline POL & Poland & 999 & Face-to-Face \\
\hline PRT & Portugal & 998 & Landline/Cellular Phone \\
\hline ROU & Romania & 994 & Face-to-Face \\
\hline RUS & Russian Federation & 1498 & Face-to-Face \\
\hline RWA & Rwanda & 1000 & Face-to-Face \\
\hline SAU & Saudi Arabia & 1035 & Face-to-Face \\
\hline SRB & Serbia & 1023 & Face-to-Face \\
\hline SUR & Suriname & 504 & Face-to-Face \\
\hline SWE & Sweden & 1000 & Landline/Cellular Phone \\
\hline THA & Thailand & 1000 & Face-to-Face \\
\hline TUR & Turkey & 1000 & Face-to-Face \\
\hline TZA & Tanzania & 1000 & Face-to-Face \\
\hline UGA & Uganda & 1000 & Face-to-Face \\
\hline UKR & Ukraine & 1000 & Face-to-Face \\
\hline USA & United States & 1072 & Landline/Cellular Phone \\
\hline VEN & Venezuela & 999 & Face-to-Face \\
\hline VNM & Vietnam & 1000 & Face-to-Face \\
\hline ZAF & South Africa & 1000 & Face-to-Face \\
\hline ZWE & Zimbabwe & 1000 & Face-to-Face \\
\hline
\end{tabular}




\section{Survey item translation and cross-country adjustment of monetary amounts}

Survey items were translated into the languages of each country according to the following

238 procedure. To make sure that no idiosyncratic errors occurred, at least three translators were involved

239 for each translation of an item in a specific target language. A first translator proposed, depending on 240 the region, an English, French, or Spanish version of the item. A second translator proficient in English,

241 French, or Spanish and the target language conducted the translation to the target language. A third

242 translator translated the item back to the original language. If discrepancies between the original item

243 and the back-translated item occurred, the procedure was repeated until all translators came to an 244 agreement.

245 Monetary amounts in the quantitative items were made comparable across countries. To do so, 246 monetary amounts were adjusted to correspond to the same share in median income (in the local 247 currency) as the share in German median income (in the original item that was experimentally 248 validated). To avoid cross-country differences in comprehensibility and to preserve simplicity of the 249 items, monetary amounts were rounded.

\section{Sampling and selection of respondents}

The within-country sampling of respondents was conducted to achieve national 253 representativeness of the resident population aged 15 and older. The area of coverage generally 254 included the entire country. Exceptions in this regard included areas where the safety of the survey 255 interviewers was endangered and, in some countries, scarcely populated islands. Interviews were either 256 conducted via landline/cellular phone or face-to-face. Telephone interviews were conducted where 257 telephone coverage represents $80 \%$ or more of the country's population or is the customary survey 258 methodology. 
Depending on the interview mode, the selection of respondents was conducted as follows. In 260 countries where telephone interviews were conducted, either a random-digit-dialing method or 261 nationally representative lists of phone numbers were used. At least three attempts were taken to reach

262 a person in each household. In countries where face-to-face interviews were conducted, primary 263 sampling units were first identified. Primary sampling units, consisting of clusters of households, were 264 stratified by population size and/ or geography. To select sampled households a random-route 265 procedure was employed. Selected households were contacted up to three times (at different times of

266 the day or on different days). A substitution method was employed if the initially sampled household 267 could not be interviewed. In both face-to-face and telephone interviews respondents were selected 268 randomly by either the latest birthday or Kish grid method.

\section{Definition of religion}

The information on religious identity is taken from the World Gallup Poll. The survey item includes the following question "Could you tell me what is your religion?" Respondents that reported any religion were classified as religious. Respondents that reported secular, non-religious, agnostic, atheist or none were classified as non-religious. In our sample (World Gallup Poll 2012), data on religious identity is available for 71 countries and for 71,520 respondents. For five countries data on religious identity is missing: China, Saudi Arabia, Jordan, United Arab Emirates and Egypt. While we

277 can make no assumptions on religious identity in China, we classified all respondents from the Arabic speaking countries as Muslims. Our assumptions are based on information from the Pew Research

279 Center (http://www.globalreligiousfutures.org/countries). According to Pew's sources, the large 280 majority of people living in these countries are Muslim (data for 2010: $93.0 \%$ in Saudi Arabia, 97.2 $281 \%$ in Jordan, $76.9 \%$ in United Arab Emirates and $94.9 \%$ in Egypt). Tab. S1 provides descriptive 
statistics of the religion variables broken down by country. Fig. S1 shows the fraction of members being part of a world religion across countries where the GPS was conducted.

Importantly, for robustness checks we also run regression analysis with restricted sample (71 countries). All our main results remained unchanged (see Supplementary Analysis).

The survey also includes information on religiosity. The survey item includes the following question "Is religion an important part of you daily life?" The binary variable takes the value of 0 if religion is not important, and 1 otherwise. We use this variable for robustness checks. All our main results remained unchanged when we include this variable into the main specifications (see Supplementary Analysis).

\section{Definition of additional individual-level variables}

Education level. The variable ranges from 1 to 3 according to the following classification. 1: Completed elementary education or less (up to 8 years of basic education). 2: Secondary to 3-year tertiary education and some education beyond secondary education (9-15 years of education). 3 : Completed four years of education beyond high school and/or received a 4-year college degree.

Household income bracket. Variable ranges from 1 (0 to 365 US-Dollars) to 27 (above 150,000 US-Dollars) according to the respondent's household income bracket within the country.

Subj. math skills. Self-assessment of the statement "I am good at math" on an 11-point Likert scale.

\section{Definition of institutional quality and population size variables (including sources)}

Institutional quality. Taken from the website of the POLITY IV project (see https://www.systemicpeace.org). The POLITY2 variable ranges from -10 (strongly autocratic) to +10 (strongly democratic). It is a combined measure of institutionalized democracy and institutionalized 
autocracy. For our analysis we use the average score between 2008 and 2012 for the countries where

307 the GPS was conducted. In this time period, Bosnia Herzegovina and Afghanistan were classified as

308 system missing (no score). For these two countries we added the last available POLITY2 score (-7 in

309 the year 2000 for Afghanistan; 0 in the year 1994 for Bosnia). All our main results remained unchanged

310 when we exclude Bosnia Herzegovina and Afghanistan from the sample (see Supplementary Analysis).

311 We also ran robustness checks with the value of institutional quality for the year 2012. All results

312 remained unchanged (see Supplementary Analysis).

313 Population size. Taken from the website of the World Bank (https://data.worldbank.org). For our 314 analysis we use the average population size between 2008 and 2012 for countries where the GPS was

315 conducted. We also run robustness checks with the value of population size for the year 2012. All 316 results remained unchanged (see Supplementary Analysis).

318 Details on statistical analysis

319 Statistical analysis

320 To analyze differences between religious and non-religious people as well as differences between 321 religions for social preferences we followed the following empirical strategy. First, each preference 322 was standardized at the global level. Second, for each preference $\left(p_{i}\right)$ the following individual-level 323 Ordinary Least Squares (OLS) regression with country fixed effects $\left(c_{i}\right)$ was performed on the global 324 sample,

$$
\begin{aligned}
& p_{i}=\beta_{1} \text { religion }_{i}+\beta_{2} \text { gender }_{i}+\beta_{3} \text { age }_{i}+\beta_{4} \text { age }_{i}^{2}+\beta_{5} \text { education level }_{i}
\end{aligned}
$$

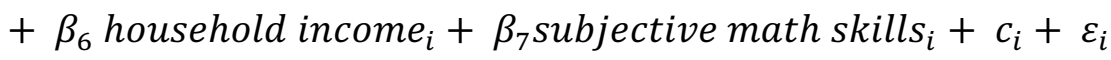

The obtained coefficient $\beta_{1}$ on the categorial variable for religion $\left(\right.$ religion $\left._{i}\right)$ serves as measure 330 of the global difference in religion for the respective preference. For the analysis we computed two 
331 versions of the categorial variable. The first one is a broad categorization of religion. It takes on the

332 value 0 if respondent is non-religious (reference group), 1 if respondent is part of a world religion (i.e.,

333 Christianity, Muslim, Hinduism, Buddhism and Judaism) and 2 if respondent belongs to a non-world

334 religion (i.e., local, primal or traditional religion). The second one is a more detailed categorization of

335 religion. It takes on the value 0 if respondent is non-religious (reference group), 1 if respondent is

336 Christian, 2 if respondent is Muslim, 3 if respondent is Hindu, 4 if respondent is Buddhist, 5 if

337 respondent is Jewish and 6 if respondent belongs to a non-world religion

338 The inclusion of standard controls (i.e., gender, age, age squared, subjective math skills, education

339 level, household income, and country fixed effects) in the estimation isolates differences from

340 potentially confounding factors which differ between religious and non-religious people. $95 \%$

341 confidence intervals were computed from standard errors clustered at the country-level. To assess the

342 robustness of our results, we also ran several alternative specifications in a parallel way. Differences

343 obtained from these alternative approaches were found to be similar and are reported below (see

344 Supplementary Analysis).

346 Summary index of prosocial preferences

347 We follow Fehr and Fischbacher ${ }^{52}$ and refer to prosocial preferences as positive other-regarding

348 behaviors and beliefs. To yield a comprehensive measure of prosocial preferences, we combine

349 measures of three main facets: altruism, trust, and reciprocity. Altruism reflects an individual's

350 willingness to benefit others (without expecting anything in return), (positive) reciprocity reflects an

351 individual's willingness to reward kind behavior, and trust indicates prosocial beliefs about the actions

352 of others.

353 Our approach on how to estimate prosocial preferences is based on the following empirical and

354 theoretical considerations. The literature suggests that different aspects of positive other-regarding 355 behaviors and beliefs are positively correlated and have a common component. For example, Altmann 
et al. ${ }^{53}$ show a strong positive interpersonal correlation between positive reciprocity and trust based on incentivized choice experiments. Within the GPS, Falk et al. ${ }^{37}$ show positive relations among altruism, positive reciprocity, and trust at the individual and at the country level. To yield a comprehensive measure of individual social preferences, we combine the GPS measures - altruism, trust, and positive reciprocity - into one measure.

The prosocial preferences index was computed as follows. We used a principal component analysis to summarize positive reciprocity, altruism and trust. The predicted principal component then served as the summary index of prosocial preferences. The eigenvalues of the components are 1.477

364 (first component), 0.901 (second component), and 0.622 (third component). Therefore, the Kaiser 365 criterion ("eigenvalues greater than one" rule) also suggests a one-dimensional structure of the concept.

366 See Fig. S2 for the distribution of prosocial preferences across the globe.

367 Importantly, we also used principal component analysis to summarize alternative versions of the social preference index: i) altruism and trust and ii) negative reciprocity, positive reciprocity, altruism and trust. All our main results remained unchanged when we use these alternative summary measures of social preferences (see Supplementary Analysis).

\section{Analysis using median split of the sample}

In Fig. 2 and Fig. 3 we analyze the data using a median split of the sample. The population size

374 variable was split into respondents living in countries with small population size (below median) and

375 respondents living in countries with large population size (above median). The median value 376 corresponds to a population size of about thirty million people. See Fig. S3 for the distribution of large 377 and small population size across countries where the GPS was conducted. The institutional quality 378 variable was split into respondents living in countries with low (below the median) institutional quality 379 and members of world religions living in countries with high (above the median) institutional quality. 380 The median value corresponds to an institutional quality of 8 (values range from a low of -10 to a 
381 high of +10$)$. See Fig. S4 for the distribution of high and low institutional quality across countries 382 where the GPS was conducted.

383 Next, we performed an individual-level Ordinary Least Squares (OLS) regression of Eq. (1) for 384 each group separately (i.e., below median group and above median group). Subsequently, we tested 385 the null hypothesis of equality of the obtained coefficients (i.e., $\beta_{1}$ religion $_{i}$ of each regression) against 386 the alternative hypothesis that the linear combination of the obtained coefficients is not equal to zero.

\section{Supplementary Analysis}

This section describes the details of the supplementary analysis. The main purpose of the supplementary analysis is to test against potential confounders that may affect our baseline results in

391 Fig. 1A to C, Fig. 2A and B, and Fig. 3.

$\underline{\text { Alternative specifications without using standard controls }}$

We tested if results of Eq. (1) remain unchanged if we exclude standard controls. We ran two alternative specifications. In the first specification we excluded all individual controls and kept only 396 country fixed effects. In the second specification we included gender, age, age-squared, and country 397 fixed effects. Results on the difference between religious and non-religious people using these 398 alternative specifications confirmed our main findings (see Tab. S3 for Fig. 1A; columns 1 and 2 in 399 Tab. S5 for Fig. 1B; Tab. S9 for Fig. 1C; columns 1-4 in Tab. S11 for Fig. 2A; columns 1-4 in Tab. 400 S13 for Fig. 2B; and columns 1-8 in Tab. S16, and columns 1 and 2 in Tab. S17 for Fig. 3, respectively). 
Comparing the effect size of religion and gender

403 Fig. S5 compares the effect size of gender and religion (based on the main specification of Fig.

404 1A, see also Table S2). The estimated coefficients of religion and gender follow similar patterns with 405 two main findings standing out: i) the estimated coefficients have the same sign and are statistically 406 significantly different compared to the reference group (non-religious, and males, respectively) except 407 for religion and positive reciprocity, and ii) the estimated coefficients of religion are larger for altruism 408 and trust and smaller for negative reciprocity and positive reciprocity compared to the estimated 409 coefficients of gender. Thus, religion appears to be an important factor in explaining prosocial 410 preferences across the globe.

411 Additionally, we analyzed the heterogeneous effects of religion by gender on the social preference 412 index. Fig. S6. presents marginal effects from an OLS regression. We computed the specification in 413 Eq. (1) and added an interaction term between religion and gender. Female members of world religions 414 have on average statistically significantly higher levels of prosocial preferences compared to male 415 members of world religions $(\mathrm{P}<0.001)$. Non-religious females also have on average statistically 416 significantly higher levels of prosocial preferences compared to non-religious males $(\mathrm{P}<0.001)$.

417 Interestingly, the gender differences in prosocial preferences are smaller for members of world 418 religions than for non-religious people.

420 Alternative measures of the prosocial preference index

421 Our main analysis is based on the principal component analysis to summarize positive reciprocity, 422 altruism and trust. We tested if results of Eq. (1) remain unchanged if we use two alternative versions 423 of the social preference index. We also used principal component analysis to summarize alternative 424 versions of prosocial preferences: i) altruism and trust and ii) negative reciprocity, positive reciprocity, 425 altruism and trust. All of our main results remained unchanged when we use these alternative summary 
measures of prosocial preferences (see columns 4-5 in Tab. S5 for Fig. 1B; columns 1-4 in Tab. S12

427 for Fig. 2A; and columns 1-4 in Tab. S14 for Fig. 2B).

Punishment patterns of Jews living in Israel and outside of Israel

Fig. S7. compares punishment patterns of Jews in more detail. The results are based on the specification of Fig. 1C except that we split the religious categorical variable with respect to Jews into two parts: Jewish Israelis $(\mathrm{N}=777)$ and Jews living outside of Israel $(\mathrm{N}=59)$. Two main findings stand out: i) Jewish Israelis have significantly higher levels of second-party punishment $(\mathrm{P}<0.05)$ and negative reciprocity without punishment $(\mathrm{P}<0.01)$ compared to Jews living outside of Israel, and ii) punishment patterns of Jews living outside of Israel are statistically not distinguishable from punishment patterns of non-religious people.

\section{Controlling for religiosity}

To avoid that we conflate indifferent or uncommitted believers with completely non-religious

440 people (see for example, Galen ${ }^{43}$ ), we also controlled for the importance of religion in a respondent's 441 daily life. To do so, we ran Eq. (1) and added a control variable indicating the importance of religion. 442 The binary variable takes on a value of 1 if religion is important in daily life and 0 otherwise (note that 443 we lose observations for this variable due to missing responses in the survey). Our main results 444 remained unchanged (see columns 2, 4, 6 and 8 in Tab. S4 for Fig. 1A; Tab. S6 for Fig. 1B; and 445 columns 2, 4, and 6 in Tab. S10 for Fig. 1C).

446 Additionally, we analyzed the heterogeneous effects of religion on the social preference index, 447 by religiosity. Fig. S8A and B presents marginal effects from an OLS regression. We computed the 448 specification in Eq. (1) and added an interaction term between religion and religiosity. Three main 449 results stand out: i) people with higher religiosity are on average more prosocial compared to people 450 with lower religiosity, ii) there are no statistically significant differences in religiosity between 
members of Islam $(\mathrm{P}=0.179)$ and Buddhism $(\mathrm{P}=0.126)$ and for non-religious people $(\mathrm{P}=0.089)$ and iii $)$

452 the same patterns hold when we excluded non-religious people from the sample (Fig. S8B) except that

453 among Buddhists the difference between people with high religiosity and people with low religiosity

454 is statistically significant $(\mathrm{P}=0.033)$.

456 Comparing the effect size of religion and institutional quality

Fig. S9. compares the effect size of institutional quality and religion. The results are based on Eq.

takes on the value 0 if respondent is living in a country with low institutional quality, and 1 if respondent is living in a country with high institutional quality. The estimated coefficients of religion and institutional quality follow opposite directions with the following main finding standing out: the zero for all social preferences $(\mathrm{P}<0.001$ for negative reciprocity, positive reciprocity and trust; $\mathrm{P}<0.05$

464 for altruism).

Excluding countries from the sample that our results are not biased by this assumption, we ran regressions excluding these four countries. 
$\underline{\text { Alternative measures of population size and institutional quality }}$

In our main analysis we use average institutional quality and average population size between 2008 and 2012. We also ran regressions with the value of institutional quality and population size in the year 2012 (the year in which the survey was conducted). Our main results were robust to this alternative measure (see columns 7 and 8 in Tab. S12 for Fig. 2A; and columns 7 and 8 in Tab. S14

481 for Fig. 2B).

482

Using the mean split for institutional quality

To rule out that the median split of institutional quality drives the results of Fig. $2 \mathrm{~B}$, we ran regressions with the mean split of institutional quality. Fig. S10 shows that this exercise provided almost the same results. First, religious people are statistically significantly more prosocial compared to non-religious people across the two categories (for low institutional quality: coef. 0.272, $\mathrm{P}<0.001$, for high institutional quality: coef. 0.137, $\mathrm{P}<0.001)$. Second, members of world religions in countries with low institutional quality have statistically significantly higher levels of

490 social preferences compared to religious people in countries with high institutional quality (coef.

$491 \quad|0.136|, \mathrm{P}<0.05)$.

$\underline{\text { Controlling for kinship intensity }}$

In light of recent literature on the relationship of religion, kinship structures and institutions ${ }^{19}$, we also controlled for kinship intensity (KII) across countries. To do so, we added the standardized

496 kinship intensity index at the country level ${ }^{19}$ as a control variable to Eq. (1). Higher (lower) KII 497 corresponds to higher (lower) kinship intensity. Our main results with respect to population size and 498 institutional quality in Fig. 2A and Fig. 2B remained unchanged (see Tab. S15). 
499 Moreover, according to Schulz et al. higher kinship intensity index is negatively correlated with 500 institutional quality of countries. In Fig. S11 we ran a regression of our main specification with the 501 median split of the kinship intensity index. Results support our analysis: members of world religions 502 in countries with high kinship intensity have marginally significantly higher levels of social 503 preferences compared to religious people in countries with low kinship intensity (coef. |0.098|, $504 \mathrm{P}=0.067)$.

505

506 Controlling for variation within countries

507 Tab. S18 and Tab. S19 contain results from OLS regressions that control for potential 508 confounders that may occur due to variation within countries. We replicate our main results of Fig. 1A 509 (Tab. S18) and Fig. 1B and C (Tab. S19) by using subnational region fixed effects instead of country 510 fixed effects. All of our main findings remained unchanged. 


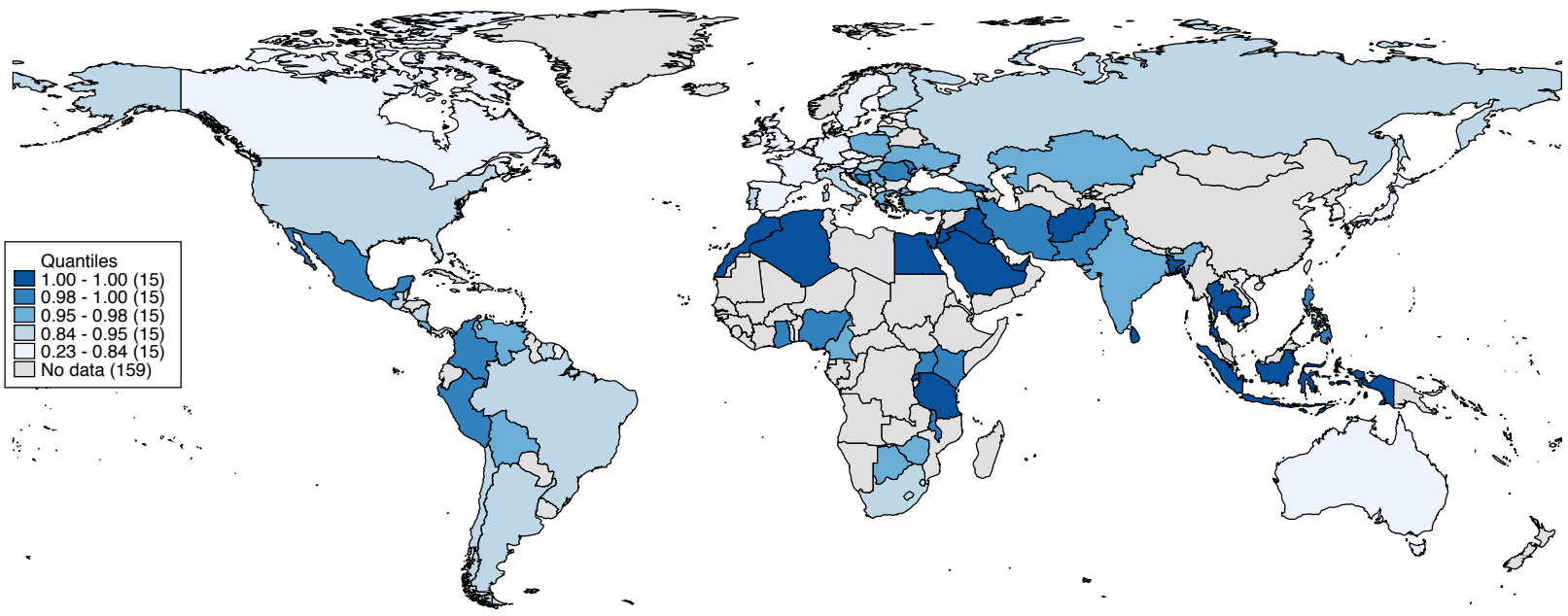

\section{Fig. S1. Global map of world religion.}

515 The map shows the fraction of respondents of the Global Preference Survey that reported a world religion (i.e., Christianity, Muslim, Hinduism, Buddhism and Judaism).

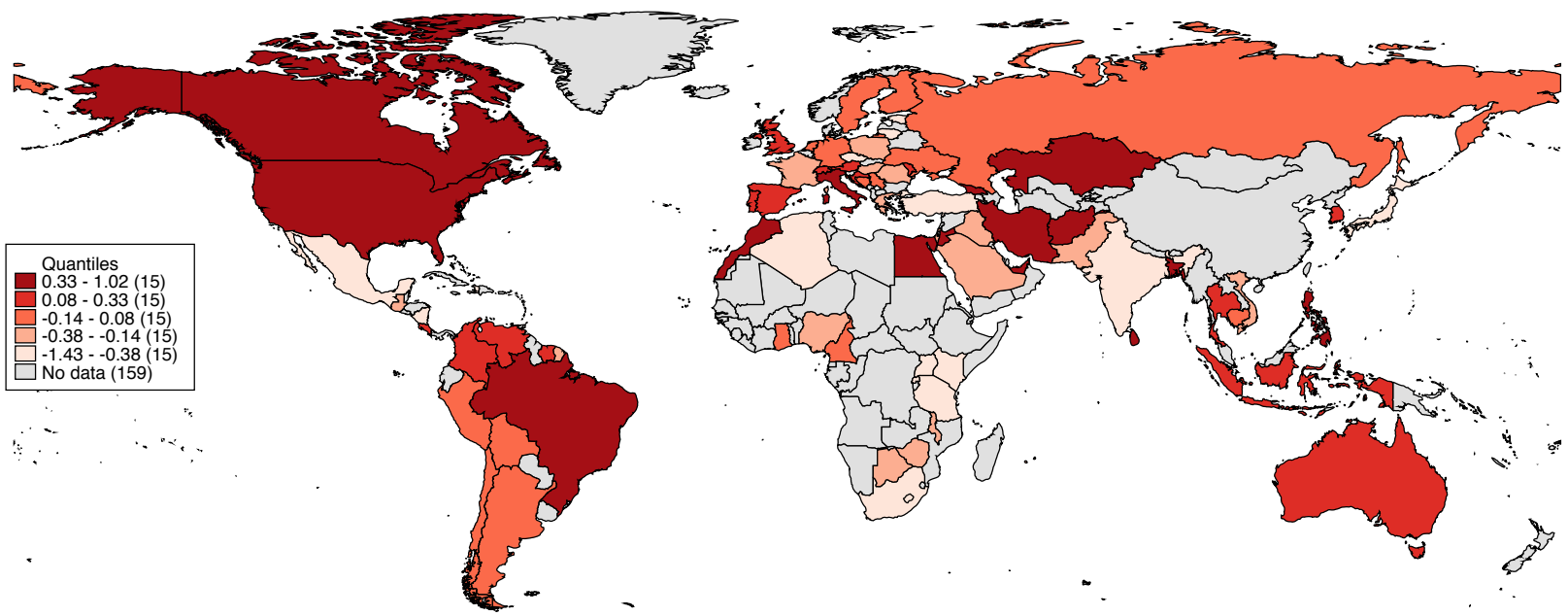

Fig. S2. Global map of prosocial preferences.

The map shows the global distribution of the prosocial preference index (i.e., the predicted principal component of positive reciprocity, altruism and trust). 


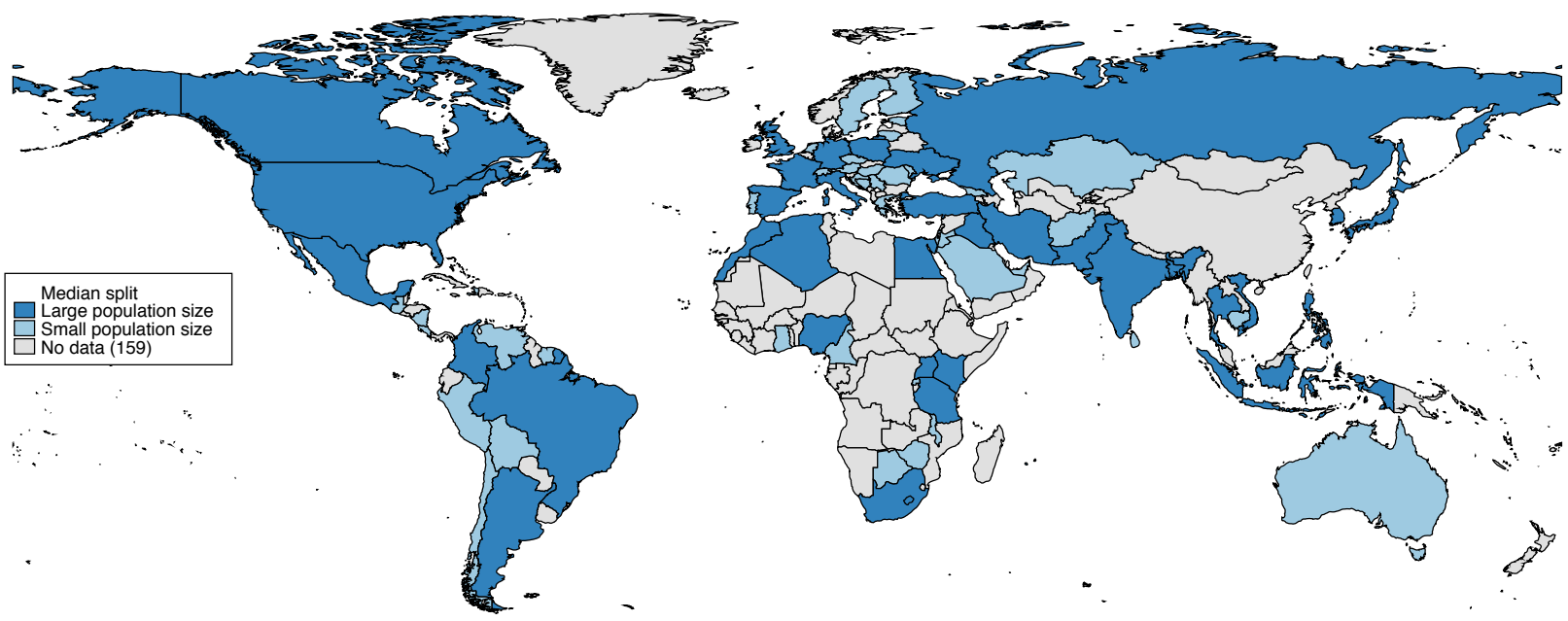

Fig. S3. Global map of population size.

530 The map shows the median split of population size across countries.

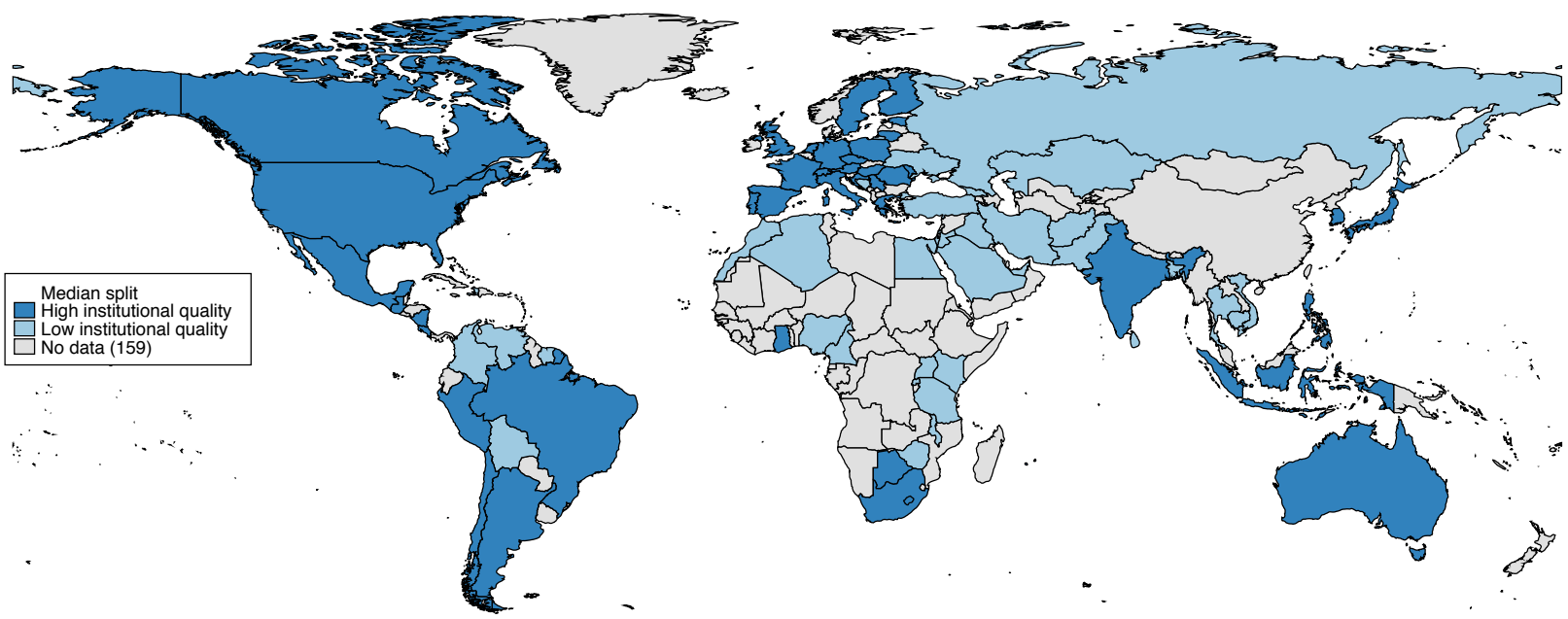

\section{Fig. S4. Global map of institutional quality.}

537 The map shows the median split of institutional quality across countries. 


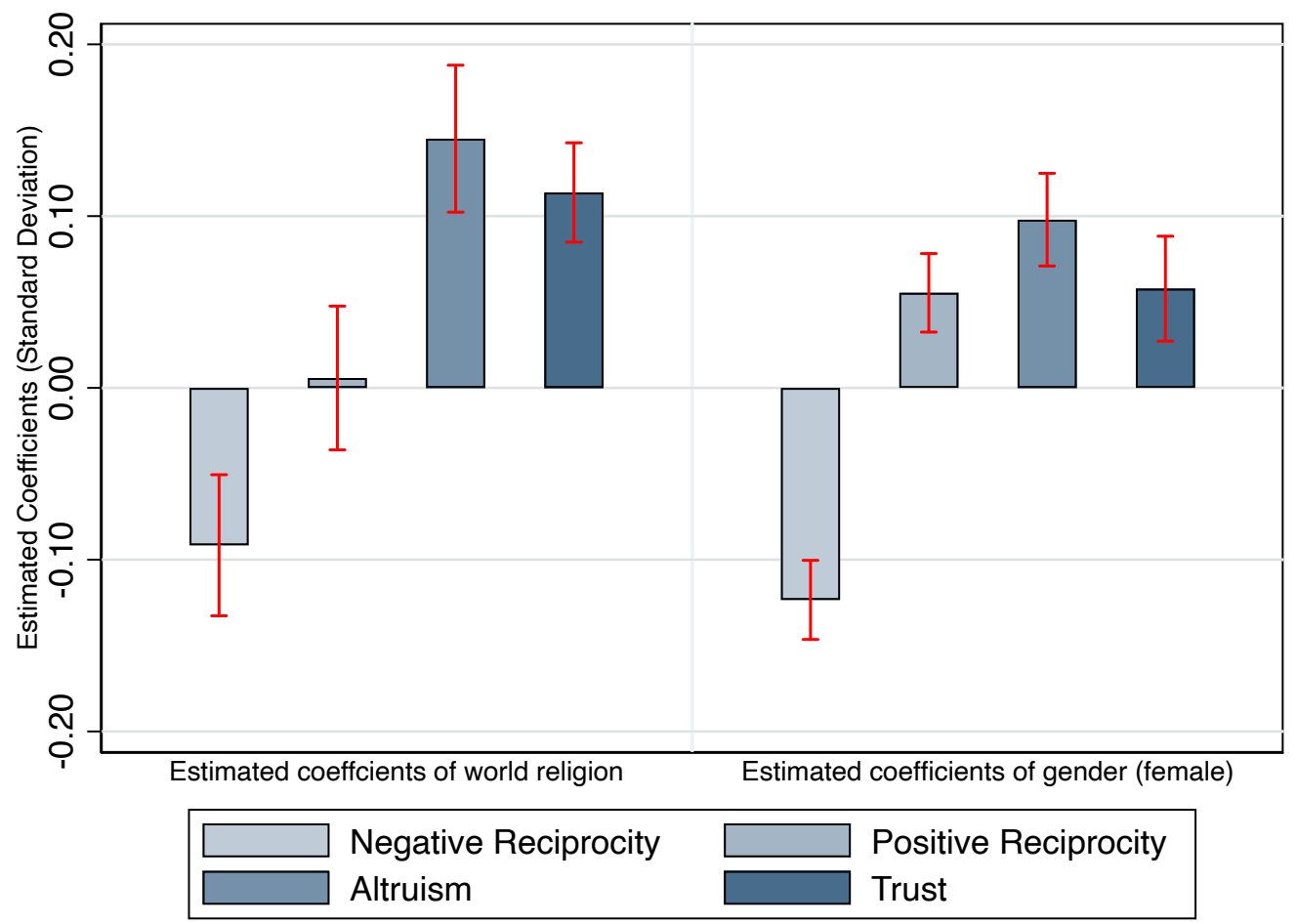

Fig. S5. Comparing effect sizes of gender and religion.

The figure plots coefficients based on an OLS regression. Positive values indicate that respondents exhibited higher levels of the respective preference, negative values indicate respondents exhibited lower levels of the respective preference. For each preference, the difference between members of world religions and nonreligious people was calculated as the coefficient on a categorical variable that takes on the value 0 if respondent is non-religious (reference group), 1 if respondent is part of a world religion (i.e., Christianity, Muslim, Hinduism, Buddhism and Judaism) and 2 if respondent belongs to a non-world religion (results not shown). The difference between males and females was calculated as the coefficient on a categorical variable that takes on the value 0 if respondent is male, and 1 respondent is female. Specifications are based on columns (1) to (4) in Tab. S2. Error bars indicate 95\% confidence intervals obtained from standard errors clustered at the country level ( $\mathrm{n}=75$ countries). 


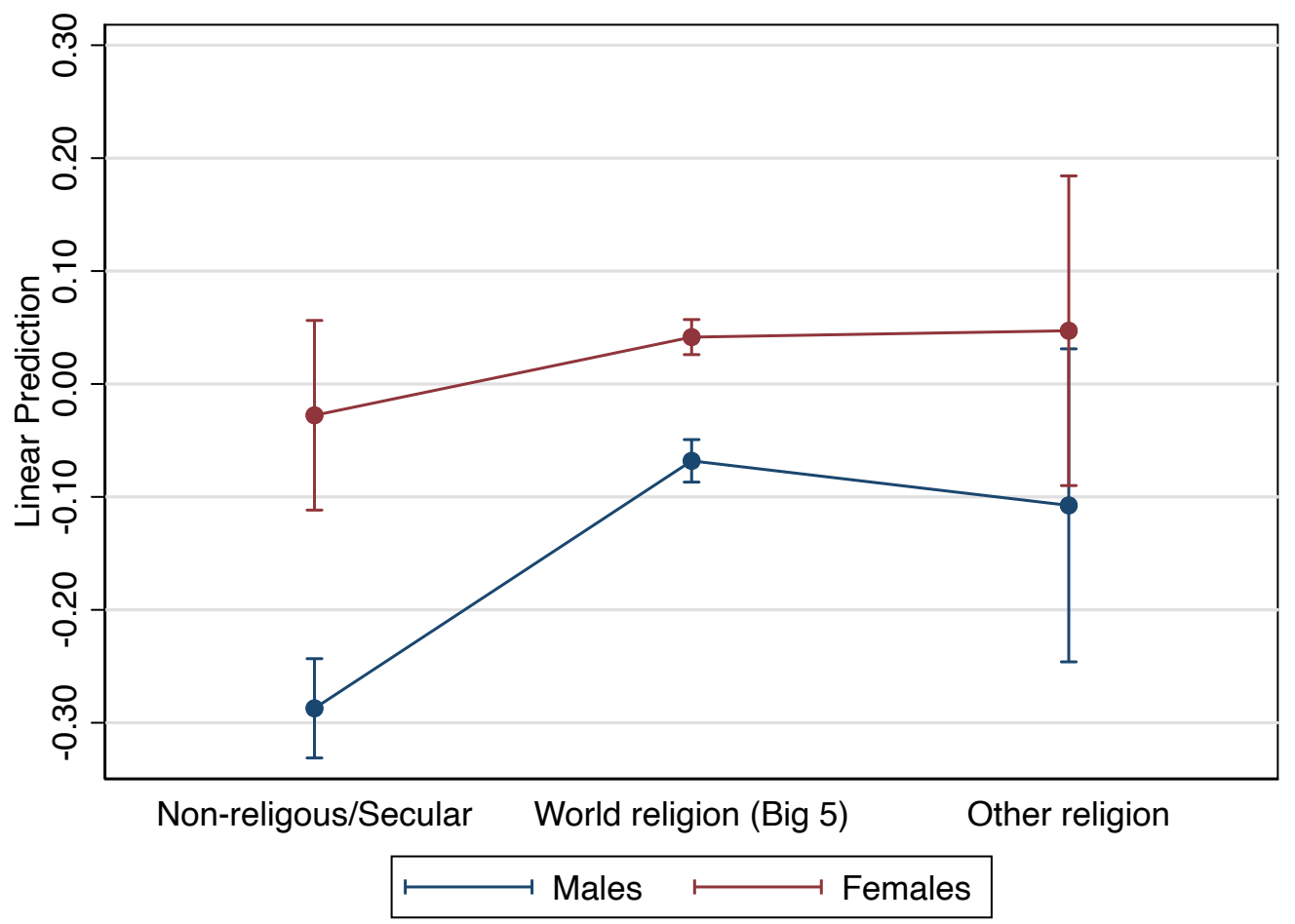

Fig. S6. Heterogeneous effects of religion by gender on prosocial preferences.

The figure plots linear predictions of an OLS regression. The coefficients can be interpreted as average marginal effects. The summary index of prosocial preferences is based on a principal component analysis of positive reciprocity, altruism and trust. Positive values indicate that respondents exhibited higher levels of prosocial preferences, negative values indicate that respondents exhibited lower levels of prosocial preferences. The difference between members of world religions and non-religious people was calculated as the coefficient on a categorical variable that takes on the value 0 if respondent is non-religious (reference group), 1 if respondent is part of a world religion (i.e., Christianity, Muslim, Hinduism, Buddhism and Judaism) and 2 if respondent belongs to a non-world religion (other religion). Specifications include the following control variables: gender, age, age squared, subjective math skills, education level, household income, and country fixed effects $(n=72,888)$. Error bars indicate $95 \%$ confidence intervals obtained from standard errors clustered at the country level $(n=75$ countries). 


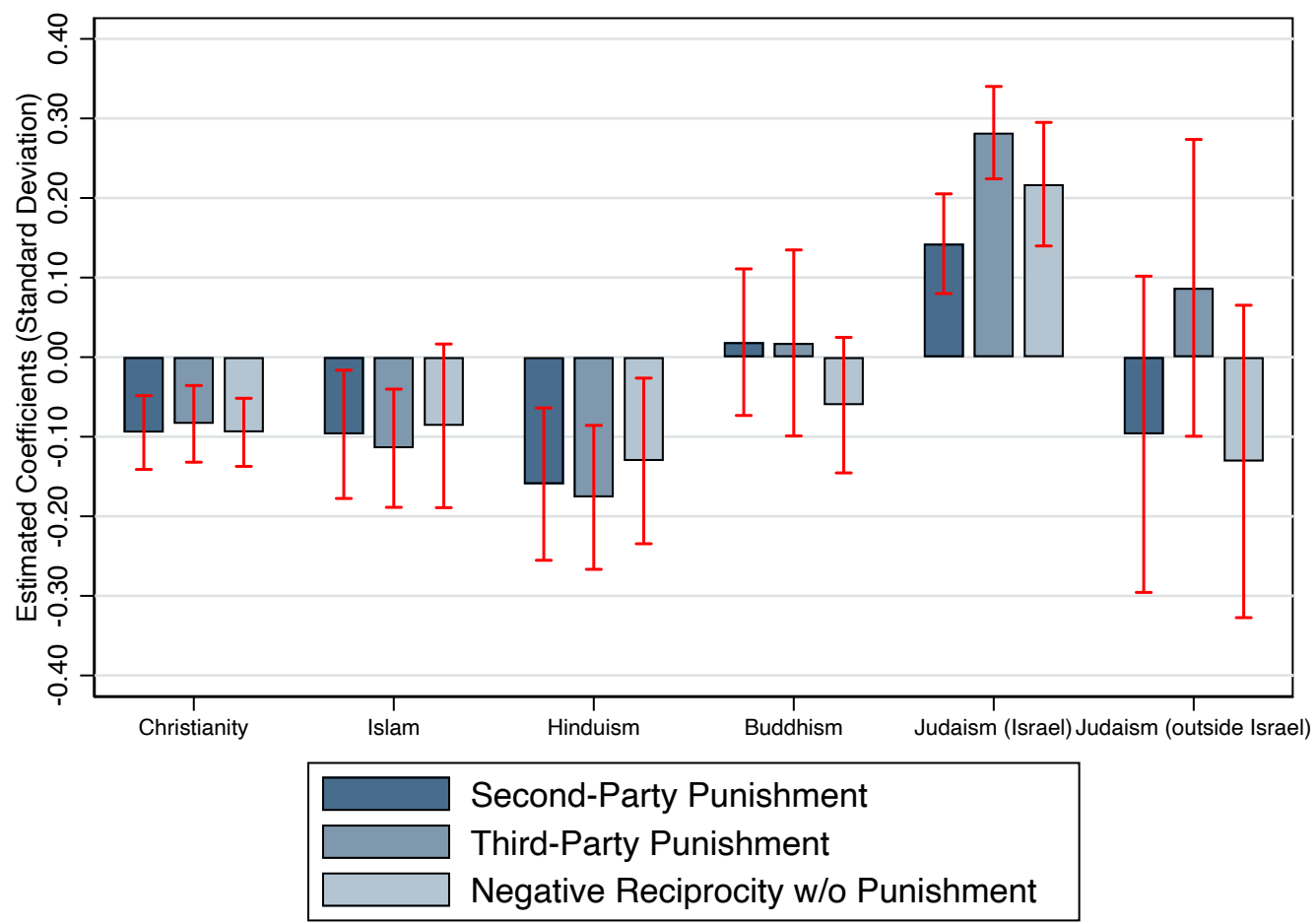

Fig. S7. Punishment patterns of Jewish Israelis and Jews living outside Israel.

The figure plots coefficients based on an OLS regression. Punishment patterns are obtained by decomposing the measure of negative reciprocity into its three components: second-party punishment, third-party punishment and negative reciprocity without punishment. Positive values indicate that members of world religions exhibited higher levels of the respective preference, negative values indicate that members of world religions exhibited lower levels of the respective preference. The difference between members of world religions and non-religious people was calculated as the coefficient on a categorical variable that takes on the value 0 if respondent is non-religious (reference group), 1 if respondent is Christian, 2 if respondent is Muslim, 3 if respondent is Hindu, 4 if respondent is Buddhist, 5 if respondent is Jewish Israeli, 6 if respondent is Jewish living outside of Israel and 7 if respondent belongs to a non-world religion (results not shown). Specifications include the following control variables: gender, age, age squared, subjective math skills, education level, household income, and country fixed effects $(n=72,888)$. Error bars indicate $95 \%$ confidence intervals obtained from standard errors clustered at the country level ( $n=75$ counries). 
(A) The heterogeneous effect of religion on prosocial preferences by religiosity.

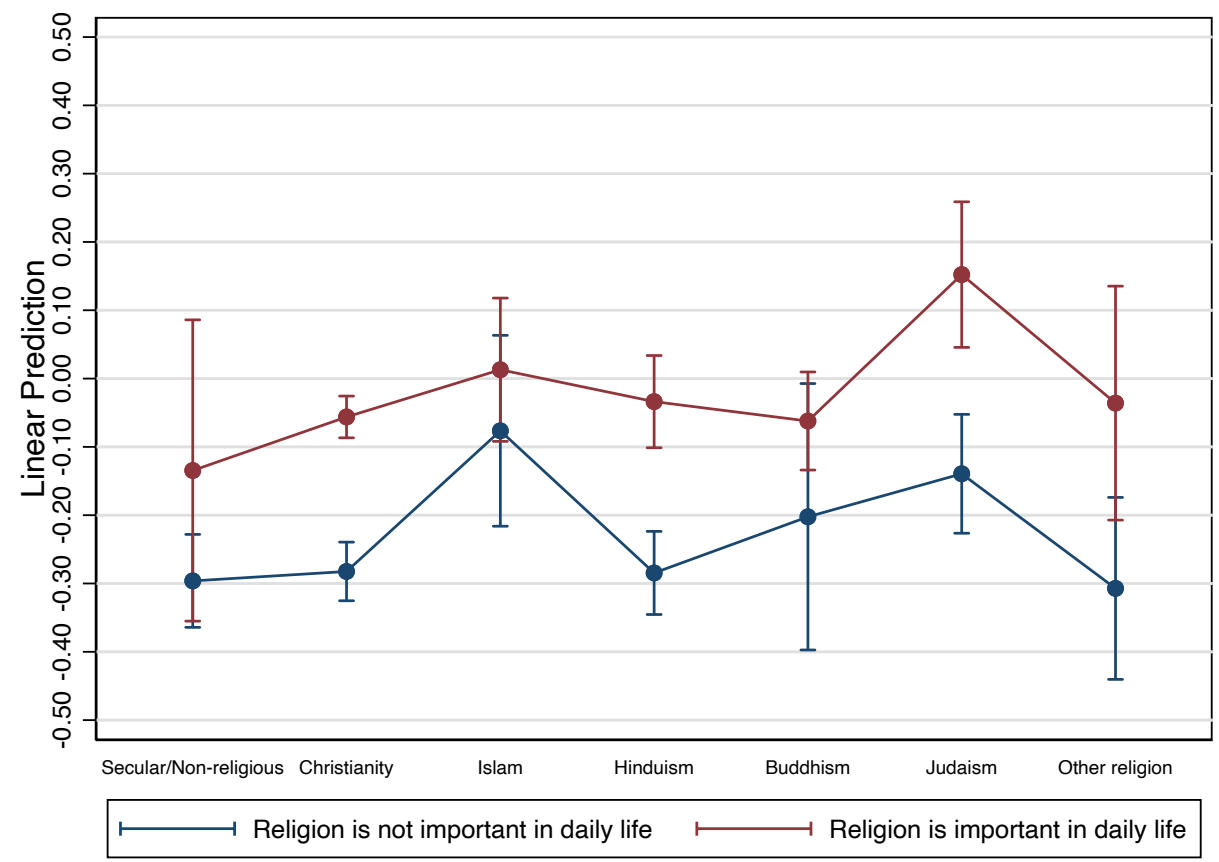

(B) The heterogeneous effect of religion on prosocial preferences by religiosity, excluding non-religious people.

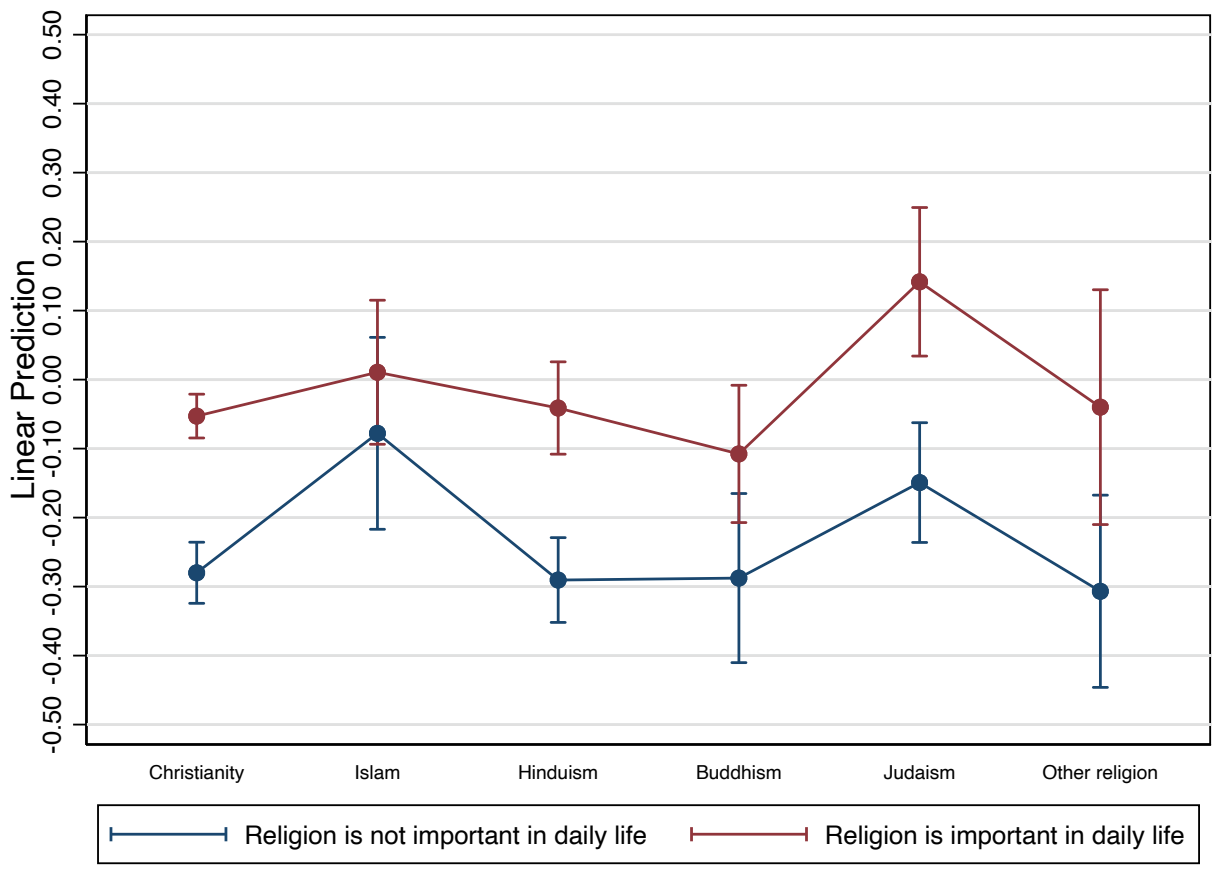



religiosity.

(A) The figure plots linear predictions of an OLS regression. The coefficients preferences is based on a principal component analysis of positive reciprocity, altruism and trust. Positive values indicate that members of world religions exhibited higher levels of prosocial preferences, negative values indicate that members of world religions exhibited lower levels of prosocial preferences. The difference between members of world religions and non-religious people was calculated as the coefficient on a categorical variable that takes on the value 0 if respondent is non-religious, 1 if respondent is Christian, 2 if respondent is Muslim, 3 if respondent is Hindu, 4 if respondent is Buddhist, 5 if respondent is Jewish and 6 if respondent belongs to a non-world religion. Results are based on the specification in Column 3 of Tab. S5. Specifications include the following control variables: gender, age, age squared, subjective math skills, education level, household income, and country fixed effects $(n=56,023)$. Error bars indicate $95 \%$ confidence intervals obtained from standard errors clustered at the country level ( $n=60$ countries).

(B) same as in (A) but excluding non-religious people form the sample $(n=52,293)$. Error bars indicate $95 \%$ confidence intervals obtained from standard errors clustered at the country level ( $\mathrm{n}=60$ countries). 


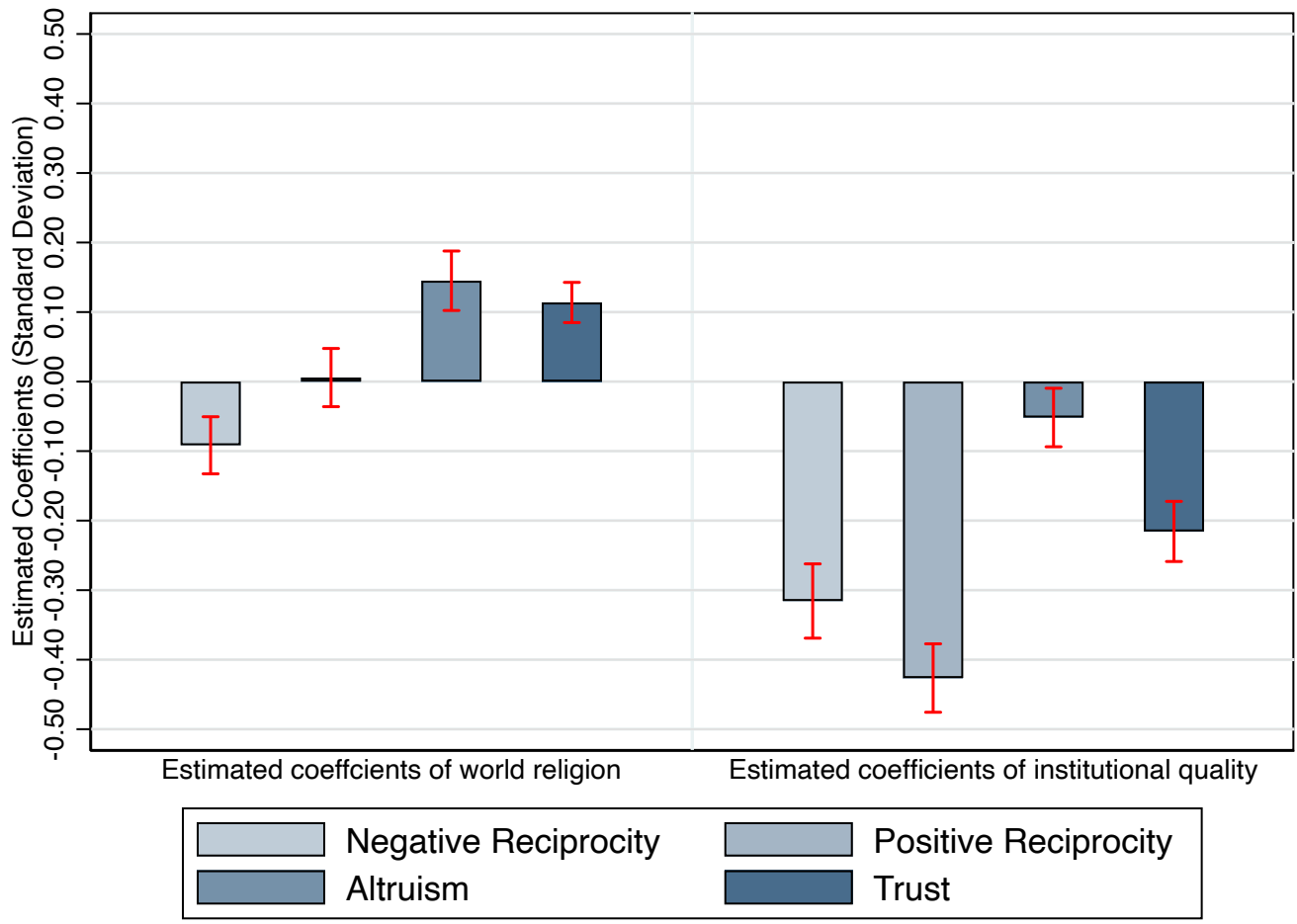

Fig. S9. Comparing effect sizes of religion and institutional quality.

The figure plots coefficients based on an OLS regression. Positive values indicate that respondents exhibited higher levels of the respective preference, negative values indicate that respondents exhibited lower levels of the respective preference. For each preference, the difference between members of world religions and non-religious people was calculated as the coefficient on a categorical variable that takes on the value 0 if respondent is non-religious (reference group), 1 if respondent is part of a world religion (i.e., Christianity, Muslim, Hinduism, Buddhism and Judaism) and 2 if respondent belongs to a non-world religion (results not shown). The difference between respondents living in countries with low vs. high institutional quality is calculated as the coefficient on a categorical variable that takes on the value 0 if respondent is living in a country with low institutional quality (below median), and 1 if respondent is living in a country with high institutional quality (above median). Specifications include the following control variables: gender, age, age squared, subjective math skills, education level, household income, and country fixed effects $(n=73,140)$. Error bars indicate $95 \%$ confidence intervals obtained from standard errors clustered at the country level ( $n=75$ countries). 


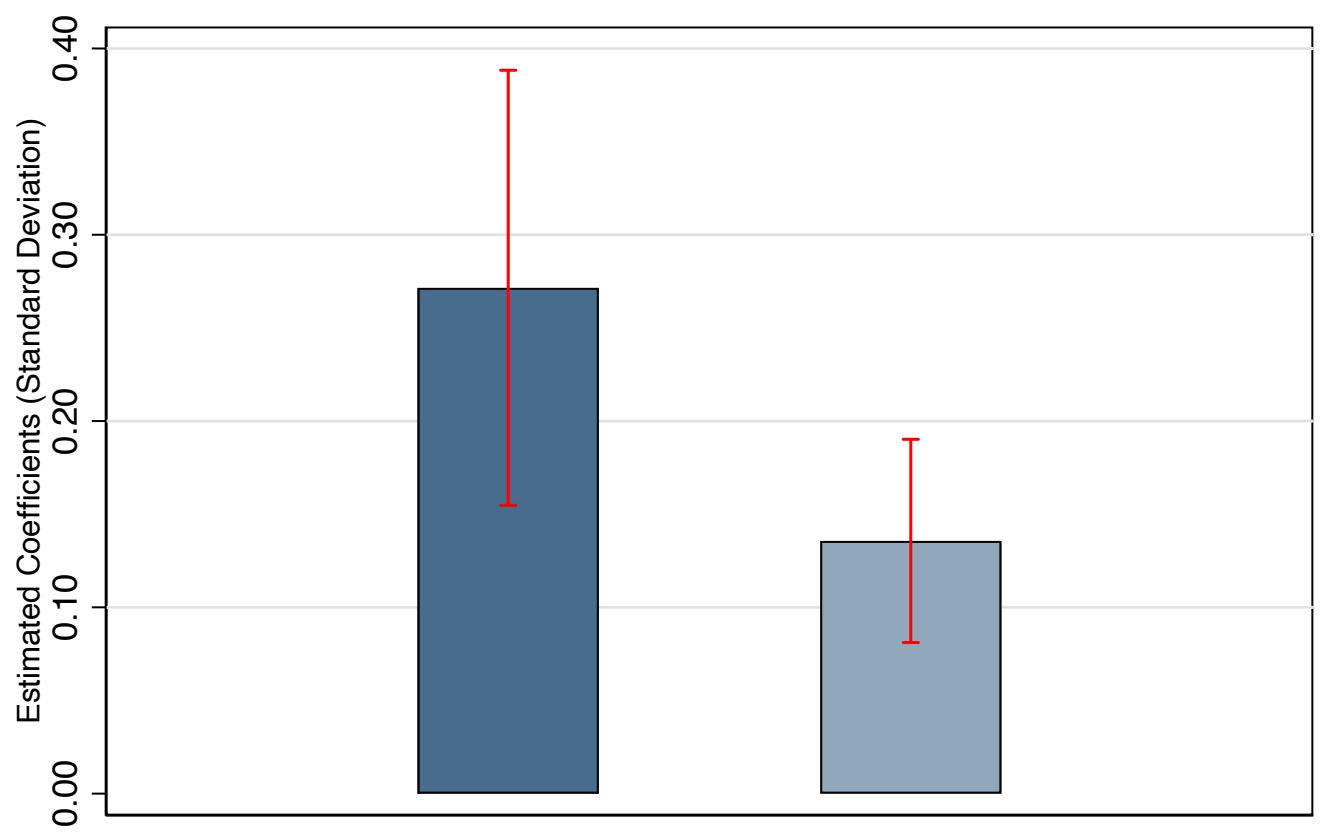

Low Institutional Quality

High Institutional Quality

641
Fig. S10. Religion and institutional quality using the mean split.

The figure plots coefficients based on an OLS regression. The sample was split into respondents living in countries with low institutional quality (below mean) and respondents living in countries with high institutional quality (above mean). The summary index of prosocial preferences is based on a principal component analysis of positive reciprocity, altruism and trust. Positive values indicate that members of world religions exhibited higher levels of the prosocial preferences, negative values indicate that members of world religions exhibited lower levels of prosocial preferences. The difference between members of world religions and non-religious people was calculated as the coefficient on a categorical variable that takes on the value 0 if respondent is non-religious (reference group), 1 if respondent is part of a world religion (i.e., Christianity, Muslim, Hinduism, Buddhism and Judaism) and 2 if respondent belongs to a non-world religion (results not shown). Specifications include the following control variables: gender, age, age squared, subjective math skills, education level, household income, and country fixed effects (low institutional quality: $n=24,140$; high institutional quality: $n=48,748$ ). Error bars indicate $95 \%$ confidence intervals obtained from standard errors clustered at the country level (low institutional quality: $n=24$ countries; high institutional quality: $n=51$ countries). 


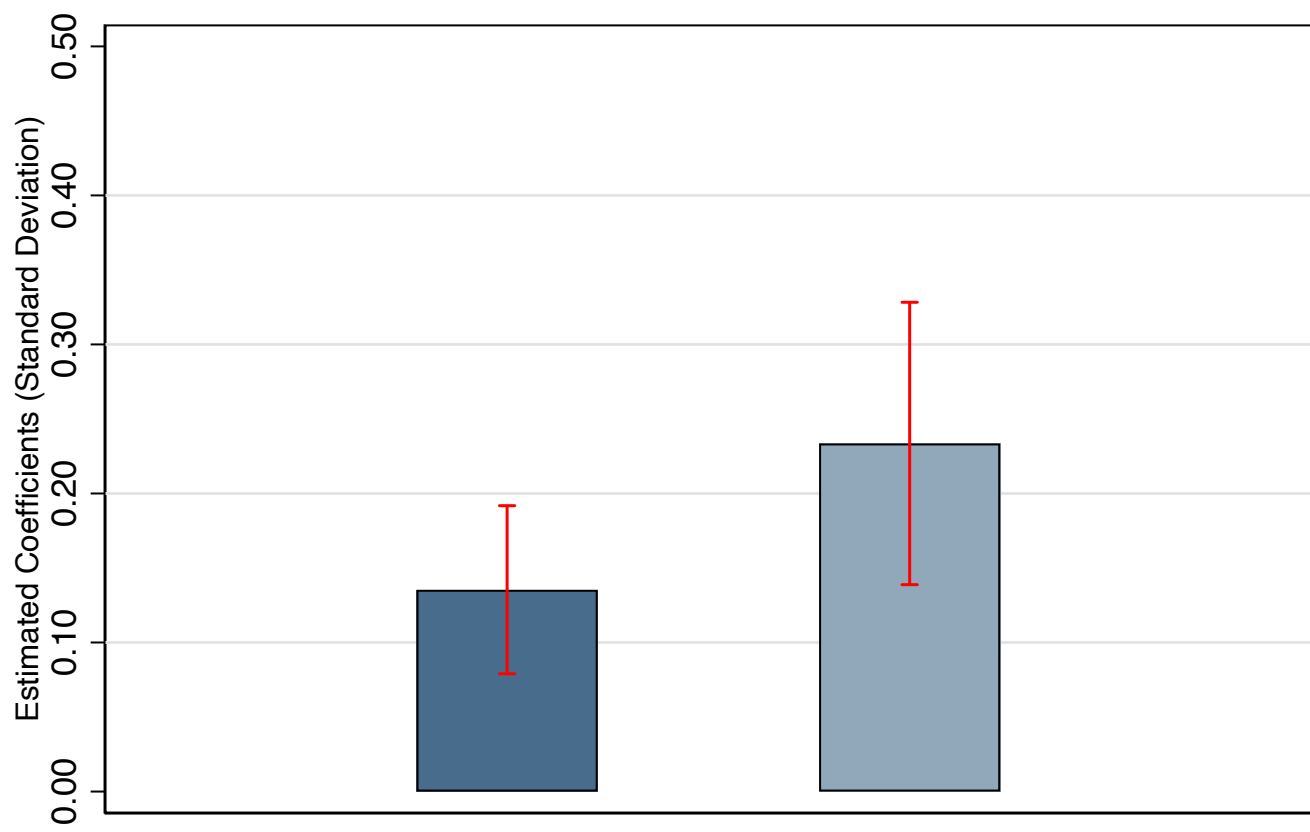

Low Kinship Intensity

High Kinship Intensity

664

665

666

667

668

669

670

671

672

673

674

675

676

677

678

679

680

681

682

683

684

685
Fig. S11. Religion and kinship: Median split by kinship intensity.

The figure plots coefficients based on an OLS regression. The sample was split into respondents living in countries with low kinship intensity (below median) and respondents living in countries with high kinship intensity (above median). The summary index of prosocial preferences is based on a principal component analysis of positive reciprocity, altruism and trust. Positive values indicate that members of world religions exhibited higher levels of the prosocial preferences, negative values indicate that members of world religions exhibited lower levels of prosocial preferences. The difference between members of world religions and non-religious people was calculated as the coefficient on a categorical variable that takes on the value 0 if respondent is non-religious (reference group), 1 if respondent is part of a world religion (i.e., Christianity, Muslim, Hinduism, Buddhism and Judaism) and 2 if respondent belongs to a non-world religion (results not shown). Specifications include the following control variables: gender, age, age squared, subjective math skills, education level, household income, and country fixed effects (low kinship intensity: $n=42,283$; high kinship intensity: $n=30,605)$. Error bars indicate $95 \%$ confidence intervals obtained from standard errors clustered at the country level (low kinship intensity: $n=46$ countries; high kinship intensity: $n=29$ countries). 


\begin{tabular}{|c|c|c|c|}
\hline Country & Variable & Mean & Std. dev. \\
\hline \multirow[t]{10}{*}{ Afghanistan } & World religion (Big Five) & 1.000 & 0.000 \\
\hline & Christianity & 0.000 & 0.000 \\
\hline & Islam & 1.000 & 0.000 \\
\hline & Hinduism & 0.000 & 0.000 \\
\hline & Buddhism & 0.000 & 0.000 \\
\hline & Judaism & 0.000 & 0.000 \\
\hline & Other religion & 0.000 & 0.000 \\
\hline & Non-religious/Secular & 0.000 & 0.000 \\
\hline & Population size & $29,316,276$ & \\
\hline & Institutional quality & -7.00 & \\
\hline \multirow[t]{10}{*}{ Algeria } & World religion (Big Five) & 1.000 & 0.000 \\
\hline & Christianity & 0.000 & 0.000 \\
\hline & Islam & 1.000 & 0.000 \\
\hline & Hinduism & 0.000 & 0.000 \\
\hline & Buddhism & 0.000 & 0.000 \\
\hline & Judaism & 0.000 & 0.000 \\
\hline & Other religion & 0.000 & 0.000 \\
\hline & Non-religious/Secular & 0.000 & 0.000 \\
\hline & Population size & $36,017,456$ & \\
\hline & Institutional quality & 2.00 & \\
\hline \multirow[t]{10}{*}{ Argentina } & World religion (Big Five) & 0.920 & 0.270 \\
\hline & Christianity & 0.920 & 0.280 \\
\hline & Islam & 0.003 & 0.056 \\
\hline & Hinduism & 0.000 & 0.000 \\
\hline & Buddhism & 0.000 & 0.000 \\
\hline & Judaism & 0.002 & 0.045 \\
\hline & Other religion & 0.008 & 0.091 \\
\hline & Non-religious/Secular & 0.070 & 0.260 \\
\hline & Population size & $40,869,232$ & \\
\hline & Institutional quality & 8.00 & \\
\hline \multirow[t]{10}{*}{ Australia } & World religion (Big Five) & 0.710 & 0.450 \\
\hline & Christianity & 0.680 & 0.470 \\
\hline & Islam & 0.012 & 0.110 \\
\hline & Hinduism & 0.007 & 0.084 \\
\hline & Buddhism & 0.009 & 0.095 \\
\hline & Judaism & 0.003 & 0.055 \\
\hline & Other religion & 0.016 & 0.130 \\
\hline & Non-religious/Secular & 0.270 & 0.450 \\
\hline & Population size & $22,009,228$ & \\
\hline & Institutional quality & 10.00 & \\
\hline
\end{tabular}

\begin{tabular}{|c|c|c|c|}
\hline Country & Variable & Mean & Std. dev. \\
\hline \multirow{10}{*}{ Austria } & World religion (Big Five) & 0.830 & 0.370 \\
\hline & Christianity & 0.820 & 0.390 \\
\hline & Islam & 0.011 & 0.110 \\
\hline & Hinduism & 0.000 & 0.000 \\
\hline & Buddhism & 0.001 & 0.032 \\
\hline & Judaism & 0.001 & 0.032 \\
\hline & Other religion & 0.001 & 0.032 \\
\hline & Non-religious/Secular & 0.170 & 0.370 \\
\hline & Population size & $8,369,972$ & \\
\hline & Institutional quality & 10.00 & \\
\hline \multirow[t]{10}{*}{ Bangladesh } & World religion (Big Five) & 1.000 & 0.032 \\
\hline & Christianity & 0.017 & 0.130 \\
\hline & Islam & 0.860 & 0.340 \\
\hline & Hinduism & 0.120 & 0.320 \\
\hline & Buddhism & 0.001 & 0.032 \\
\hline & Judaism & 0.000 & 0.000 \\
\hline & Other religion & 0.001 & 0.032 \\
\hline & Non-religious/Secular & 0.000 & 0.000 \\
\hline & Population size & $147,617,200$ & \\
\hline & Institutional quality & 2.80 & \\
\hline \multirow[t]{10}{*}{ Bolivia } & World religion (Big Five) & 0.980 & 0.140 \\
\hline & Christianity & 0.980 & 0.150 \\
\hline & Islam & 0.000 & 0.000 \\
\hline & Hinduism & 0.000 & 0.000 \\
\hline & Buddhism & 0.001 & 0.032 \\
\hline & Judaism & 0.000 & 0.000 \\
\hline & Other religion & 0.008 & 0.090 \\
\hline & Non-religious/Secular & 0.013 & 0.110 \\
\hline & Population size & $10,049,091$ & \\
\hline & Institutional quality & 7.20 & \\
\hline \multirow{11}{*}{$\begin{array}{l}\text { Bosnia } \\
\text { Herzegovina }\end{array}$} & World religion (Big Five) & & \\
\hline & & 1.000 & 0.045 \\
\hline & Christianity & 0.670 & 0.470 \\
\hline & Islam & 0.320 & 0.470 \\
\hline & Hinduism & 0.000 & 0.000 \\
\hline & Buddhism & 0.001 & 0.032 \\
\hline & Judaism & 0.000 & 0.000 \\
\hline & Other religion & 0.001 & 0.032 \\
\hline & Non-religious/Secular & 0.001 & 0.032 \\
\hline & Population size & $3,692,366$ & \\
\hline & Institutional quality & 0.00 & \\
\hline
\end{tabular}




\begin{tabular}{|c|c|c|c|}
\hline Country & Variable & Mean & Std. dev. \\
\hline \multirow[t]{10}{*}{ Botswana } & World religion (Big Five) & 0.950 & 0.220 \\
\hline & Christianity & 0.940 & 0.230 \\
\hline & Islam & 0.006 & 0.078 \\
\hline & Hinduism & 0.001 & 0.032 \\
\hline & Buddhism & 0.001 & 0.032 \\
\hline & Judaism & 0.000 & 0.000 \\
\hline & Other religion & 0.023 & 0.150 \\
\hline & Non-religious/Secular & 0.026 & 0.160 \\
\hline & Population size & $1,982,239$ & \\
\hline & Institutional quality & 8.00 & \\
\hline \multirow[t]{10}{*}{ Brazil } & World religion (Big Five) & 0.930 & 0.250 \\
\hline & Christianity & 0.930 & 0.260 \\
\hline & Islam & 0.005 & 0.071 \\
\hline & Hinduism & 0.002 & 0.045 \\
\hline & Buddhism & 0.001 & 0.032 \\
\hline & Judaism & 0.000 & 0.000 \\
\hline & Other religion & 0.035 & 0.180 \\
\hline & Non-religious/Secular & 0.031 & 0.170 \\
\hline & Population size & $195,686,464$ & \\
\hline & Institutional quality & 8.00 & \\
\hline \multirow[t]{10}{*}{ Cambodia } & World religion (Big Five) & 1.000 & 0.000 \\
\hline & Christianity & 0.004 & 0.063 \\
\hline & Islam & 0.012 & 0.110 \\
\hline & Hinduism & 0.002 & 0.045 \\
\hline & Buddhism & 0.980 & 0.130 \\
\hline & Judaism & 0.000 & 0.000 \\
\hline & Other religion & 0.000 & 0.000 \\
\hline & Non-religious/Secular & 0.000 & 0.000 \\
\hline & Population size & $14,322,305$ & \\
\hline & Institutional quality & 2.00 & \\
\hline \multirow[t]{10}{*}{ Cameroon } & World religion (Big Five) & 0.960 & 0.190 \\
\hline & Christianity & 0.830 & 0.380 \\
\hline & Islam & 0.130 & 0.340 \\
\hline & Hinduism & 0.000 & 0.000 \\
\hline & Buddhism & 0.000 & 0.000 \\
\hline & Judaism & 0.000 & 0.000 \\
\hline & Other religion & 0.031 & 0.170 \\
\hline & Non-religious/Secular & 0.008 & 0.089 \\
\hline & Population size & $20,355,096$ & \\
\hline & Institutional quality & -4.00 & \\
\hline
\end{tabular}

\begin{tabular}{|c|c|c|c|}
\hline Country & Variable & Mean & Std. dev. \\
\hline \multirow[t]{10}{*}{ Canada } & World religion (Big Five) & 0.770 & 0.420 \\
\hline & Christianity & 0.730 & 0.440 \\
\hline & Islam & 0.019 & 0.140 \\
\hline & Hinduism & 0.004 & 0.065 \\
\hline & Buddhism & 0.007 & 0.086 \\
\hline & Judaism & 0.007 & 0.086 \\
\hline & Other religion & 0.025 & 0.160 \\
\hline & Non-religious/Secular & 0.210 & 0.410 \\
\hline & Population size & $33,986,892$ & \\
\hline & Institutional quality & 10.00 & \\
\hline \multirow[t]{10}{*}{ Chile } & World religion (Big Five) & 0.900 & 0.300 \\
\hline & Christianity & 0.900 & 0.300 \\
\hline & Islam & 0.001 & 0.032 \\
\hline & Hinduism & 0.001 & 0.032 \\
\hline & Buddhism & 0.002 & 0.045 \\
\hline & Judaism & 0.000 & 0.000 \\
\hline & Other religion & 0.012 & 0.110 \\
\hline & Non-religious/Secular & 0.085 & 0.280 \\
\hline & Population size & $17,058,180$ & \\
\hline & Institutional quality & 10.00 & \\
\hline \multirow[t]{10}{*}{ Colombia } & World religion (Big Five) & 0.990 & 0.110 \\
\hline & Christianity & 0.980 & 0.130 \\
\hline & Islam & 0.000 & 0.000 \\
\hline & Hinduism & 0.000 & 0.000 \\
\hline & Buddhism & 0.002 & 0.045 \\
\hline & Judaism & 0.002 & 0.045 \\
\hline & Other religion & 0.004 & 0.064 \\
\hline & Non-religious/Secular & 0.008 & 0.090 \\
\hline & Population size & $45,193,536$ & \\
\hline & Institutional quality & 7.00 & \\
\hline \multirow[t]{10}{*}{ Costa Rica } & World religion (Big Five) & 0.950 & 0.210 \\
\hline & Christianity & 0.950 & 0.230 \\
\hline & Islam & 0.001 & 0.032 \\
\hline & Hinduism & 0.003 & 0.055 \\
\hline & Buddhism & 0.001 & 0.032 \\
\hline & Judaism & 0.001 & 0.032 \\
\hline & Other religion & 0.016 & 0.130 \\
\hline & Non-religious/Secular & 0.031 & 0.170 \\
\hline & Population size & $4,576,466$ & \\
\hline & Institutional quality & 10.00 & \\
\hline
\end{tabular}




\begin{tabular}{|c|c|c|c|}
\hline Country & Variable & Mean & Std. dev. \\
\hline \multirow[t]{10}{*}{ Croatia } & World religion (Big Five) & 0.960 & 0.190 \\
\hline & Christianity & 0.960 & 0.200 \\
\hline & Islam & 0.004 & 0.065 \\
\hline & Hinduism & 0.000 & 0.000 \\
\hline & Buddhism & 0.002 & 0.046 \\
\hline & Judaism & 0.000 & 0.000 \\
\hline & Other religion & 0.000 & 0.000 \\
\hline & Non-religious/Secular & 0.036 & 0.190 \\
\hline & Population size & $4,291,699$ & \\
\hline & Institutional quality & 9.00 & \\
\hline \multirow[t]{10}{*}{ Czech Republic } & World religion (Big Five) & 0.230 & 0.420 \\
\hline & Christianity & 0.220 & 0.420 \\
\hline & Islam & 0.000 & 0.000 \\
\hline & Hinduism & 0.000 & 0.000 \\
\hline & Buddhism & 0.001 & 0.033 \\
\hline & Judaism & 0.000 & 0.000 \\
\hline & Other religion & 0.000 & 0.000 \\
\hline & Non-religious/Secular & 0.770 & 0.420 \\
\hline & Population size & $10,461,964$ & \\
\hline & Institutional quality & 9.00 & \\
\hline \multirow[t]{10}{*}{ Egypt } & World religion (Big Five) & 1.000 & 0.000 \\
\hline & Christianity & 0.000 & 0.000 \\
\hline & Islam & 1.000 & 0.000 \\
\hline & Hinduism & 0.000 & 0.000 \\
\hline & Buddhism & 0.000 & 0.000 \\
\hline & Judaism & 0.000 & 0.000 \\
\hline & Other religion & 0.000 & 0.000 \\
\hline & Non-religious/Secular & 0.000 & 0.000 \\
\hline & Population size & $82,896,720$ & \\
\hline & Institutional quality & -2.80 & \\
\hline \multirow[t]{10}{*}{ Estonia } & World religion (Big Five) & 0.620 & 0.480 \\
\hline & Christianity & 0.620 & 0.490 \\
\hline & Islam & 0.001 & 0.034 \\
\hline & Hinduism & 0.001 & 0.034 \\
\hline & Buddhism & 0.002 & 0.048 \\
\hline & Judaism & 0.001 & 0.034 \\
\hline & Other religion & 0.017 & 0.130 \\
\hline & Non-religious/Secular & 0.360 & 0.480 \\
\hline & Population size & $1,330,643$ & \\
\hline & Institutional quality & 9.00 & \\
\hline
\end{tabular}

\begin{tabular}{|c|c|c|c|}
\hline Country & Variable & Mean & Std. dev. \\
\hline \multirow[t]{10}{*}{ Finland } & World religion (Big Five) & 0.850 & 0.350 \\
\hline & Christianity & 0.850 & 0.360 \\
\hline & Islam & 0.001 & 0.032 \\
\hline & Hinduism & 0.000 & 0.000 \\
\hline & Buddhism & 0.000 & 0.000 \\
\hline & Judaism & 0.001 & 0.032 \\
\hline & Other religion & 0.015 & 0.120 \\
\hline & Non-religious/Secular & 0.130 & 0.340 \\
\hline & Population size & $5,363,573$ & \\
\hline & Institutional quality & 10.00 & \\
\hline \multirow[t]{10}{*}{ France } & World religion (Big Five) & 0.690 & 0.460 \\
\hline & Christianity & 0.630 & 0.480 \\
\hline & Islam & 0.053 & 0.220 \\
\hline & Hinduism & 0.000 & 0.000 \\
\hline & Buddhism & 0.001 & 0.033 \\
\hline & Judaism & 0.003 & 0.057 \\
\hline & Other religion & 0.004 & 0.066 \\
\hline & Non-religious/Secular & 0.310 & 0.460 \\
\hline & Population size & $65,022,424$ & \\
\hline & Institutional quality & 9.00 & \\
\hline \multirow[t]{10}{*}{ Georgia } & World religion (Big Five) & 1.000 & 0.000 \\
\hline & Christianity & 0.940 & 0.240 \\
\hline & Islam & 0.063 & 0.240 \\
\hline & Hinduism & 0.000 & 0.000 \\
\hline & Buddhism & 0.000 & 0.000 \\
\hline & Judaism & 0.000 & 0.000 \\
\hline & Other religion & 0.000 & 0.000 \\
\hline & Non-religious/Secular & 0.000 & 0.000 \\
\hline & Population size & $3,786,976$ & \\
\hline & Institutional quality & 6.00 & \\
\hline \multirow[t]{10}{*}{ Germany } & World religion (Big Five) & 0.670 & 0.470 \\
\hline & Christianity & 0.660 & 0.470 \\
\hline & Islam & 0.012 & 0.110 \\
\hline & Hinduism & 0.000 & 0.000 \\
\hline & Buddhism & 0.001 & 0.032 \\
\hline & Judaism & 0.001 & 0.032 \\
\hline & Other religion & 0.002 & 0.045 \\
\hline & Non-religious/Secular & 0.320 & 0.470 \\
\hline & Population size & $81,298,032$ & \\
\hline & Institutional quality & 10.00 & \\
\hline
\end{tabular}




\begin{tabular}{|c|c|c|c|}
\hline Country & Variable & Mean & Std. dev. \\
\hline \multirow[t]{10}{*}{ Ghana } & World religion (Big Five) & 0.990 & 0.100 \\
\hline & Christianity & 0.890 & 0.310 \\
\hline & Islam & 0.096 & 0.290 \\
\hline & Hinduism & 0.000 & 0.000 \\
\hline & Buddhism & 0.000 & 0.000 \\
\hline & Judaism & 0.001 & 0.032 \\
\hline & Other religion & 0.010 & 0.100 \\
\hline & Non-religious/Secular & 0.001 & 0.032 \\
\hline & Population size & $24,779,708$ & \\
\hline & Institutional quality & 8.00 & \\
\hline \multirow[t]{10}{*}{ Greece } & World religion (Big Five) & 0.980 & 0.150 \\
\hline & Christianity & 0.940 & 0.230 \\
\hline & Islam & 0.034 & 0.180 \\
\hline & Hinduism & 0.001 & 0.032 \\
\hline & Buddhism & 0.000 & 0.000 \\
\hline & Judaism & 0.000 & 0.000 \\
\hline & Other religion & 0.000 & 0.000 \\
\hline & Non-religious/Secular & 0.022 & 0.150 \\
\hline & Population size & $11,091,222$ & \\
\hline & Institutional quality & 10.00 & \\
\hline \multirow[t]{10}{*}{ Guatemala } & World religion (Big Five) & 0.920 & 0.270 \\
\hline & Christianity & 0.920 & 0.270 \\
\hline & Islam & 0.000 & 0.000 \\
\hline & Hinduism & 0.001 & 0.032 \\
\hline & Buddhism & 0.000 & 0.000 \\
\hline & Judaism & 0.000 & 0.000 \\
\hline & Other religion & 0.000 & 0.000 \\
\hline & Non-religious/Secular & 0.081 & 0.270 \\
\hline & Population size & $14,634,538$ & \\
\hline & Institutional quality & 8.00 & \\
\hline \multirow[t]{10}{*}{ Haiti } & World religion (Big Five) & 0.940 & 0.230 \\
\hline & Christianity & 0.920 & 0.280 \\
\hline & Islam & 0.016 & 0.130 \\
\hline & Hinduism & 0.002 & 0.045 \\
\hline & Buddhism & 0.006 & 0.078 \\
\hline & Judaism & 0.000 & 0.000 \\
\hline & Other religion & 0.036 & 0.190 \\
\hline & Non-religious/Secular & 0.022 & 0.150 \\
\hline & Population size & $9,949,040$ & \\
\hline & Institutional quality & 2.00 & \\
\hline
\end{tabular}

\begin{tabular}{|c|c|c|c|}
\hline Country & Variable & Mean & Std. dev. \\
\hline \multirow[t]{10}{*}{ Hungary } & World religion (Big Five) & 0.860 & 0.350 \\
\hline & Christianity & 0.860 & 0.350 \\
\hline & Islam & 0.000 & 0.000 \\
\hline & Hinduism & 0.000 & 0.000 \\
\hline & Buddhism & 0.001 & 0.032 \\
\hline & Judaism & 0.001 & 0.032 \\
\hline & Other religion & 0.002 & 0.046 \\
\hline & Non-religious/Secular & 0.140 & 0.350 \\
\hline & Population size & $9,990,590$ & \\
\hline & Institutional quality & 10.00 & \\
\hline \multirow[t]{10}{*}{ India } & World religion (Big Five) & 0.970 & 0.170 \\
\hline & Christianity & 0.026 & 0.160 \\
\hline & Islam & 0.160 & 0.370 \\
\hline & Hinduism & 0.780 & 0.410 \\
\hline & Buddhism & 0.006 & 0.074 \\
\hline & Judaism & 0.000 & 0.000 \\
\hline & Other religion & 0.028 & 0.170 \\
\hline & Non-religious/Secular & 0.000 & 0.000 \\
\hline & Population size & $1,233,749,760$ & \\
\hline & Institutional quality & 9.00 & \\
\hline \multirow[t]{10}{*}{ Indonesia } & World religion (Big Five) & 1.000 & 0.000 \\
\hline & Christianity & 0.110 & 0.310 \\
\hline & Islam & 0.870 & 0.340 \\
\hline & Hinduism & 0.019 & 0.140 \\
\hline & Buddhism & 0.003 & 0.055 \\
\hline & Judaism & 0.000 & 0.000 \\
\hline & Other religion & 0.000 & 0.000 \\
\hline & Non-religious/Secular & 0.000 & 0.000 \\
\hline & Population size & $241,898,624$ & \\
\hline & Institutional quality & 8.00 & \\
\hline \multirow[t]{10}{*}{ Iran } & World religion (Big Five) & 1.000 & 0.060 \\
\hline & Christianity & 0.003 & 0.057 \\
\hline & Islam & 0.990 & 0.085 \\
\hline & Hinduism & 0.000 & 0.000 \\
\hline & Buddhism & 0.000 & 0.000 \\
\hline & Judaism & 0.000 & 0.020 \\
\hline & Other religion & 0.002 & 0.040 \\
\hline & Non-religious/Secular & 0.002 & 0.045 \\
\hline & Population size & $73,796,552$ & \\
\hline & Institutional quality & -6.80 & \\
\hline
\end{tabular}




\begin{tabular}{|c|c|c|c|}
\hline Country & Variable & Mean & Std. dev. \\
\hline \multirow[t]{10}{*}{ Iraq } & World religion (Big Five) & 1.000 & 0.000 \\
\hline & Christianity & 0.032 & 0.180 \\
\hline & Islam & 0.970 & 0.180 \\
\hline & Hinduism & 0.000 & 0.000 \\
\hline & Buddhism & 0.000 & 0.000 \\
\hline & Judaism & 0.000 & 0.000 \\
\hline & Other religion & 0.000 & 0.000 \\
\hline & Non-religious/Secular & 0.000 & 0.000 \\
\hline & Population size & $29,943,240$ & \\
\hline & Institutional quality & 3.00 & \\
\hline \multirow[t]{10}{*}{ Israel } & World religion (Big Five) & 0.970 & 0.170 \\
\hline & Christianity & 0.031 & 0.170 \\
\hline & Islam & 0.160 & 0.360 \\
\hline & Hinduism & 0.000 & 0.000 \\
\hline & Buddhism & 0.000 & 0.000 \\
\hline & Judaism & 0.780 & 0.410 \\
\hline & Other religion & 0.014 & 0.120 \\
\hline & Non-religious/Secular & 0.016 & 0.130 \\
\hline & Population size & $7,618,860$ & \\
\hline & Institutional quality & 6.00 & \\
\hline \multirow[t]{10}{*}{ Italy } & World religion (Big Five) & 0.900 & 0.310 \\
\hline & Christianity & 0.880 & 0.320 \\
\hline & Islam & 0.006 & 0.078 \\
\hline & Hinduism & 0.001 & 0.032 \\
\hline & Buddhism & 0.003 & 0.055 \\
\hline & Judaism & 0.001 & 0.032 \\
\hline & Other religion & 0.002 & 0.045 \\
\hline & Non-religious/Secular & 0.100 & 0.300 \\
\hline & Population size & $59,223,736$ & \\
\hline & Institutional quality & 10.00 & \\
\hline \multirow[t]{10}{*}{ Japan } & World religion (Big Five) & 0.300 & 0.460 \\
\hline & Christianity & 0.024 & 0.150 \\
\hline & Islam & 0.001 & 0.032 \\
\hline & Hinduism & 0.001 & 0.032 \\
\hline & Buddhism & 0.270 & 0.450 \\
\hline & Judaism & 0.000 & 0.000 \\
\hline & Other religion & 0.031 & 0.170 \\
\hline & Non-religious/Secular & 0.670 & 0.470 \\
\hline & Population size & $127,928,400$ & \\
\hline & Institutional quality & 10.00 & \\
\hline
\end{tabular}

\begin{tabular}{|c|c|c|c|}
\hline Country & Variable & Mean & Std. dev. \\
\hline \multirow[t]{10}{*}{ Jordan } & World religion (Big Five) & 1.000 & 0.000 \\
\hline & Christianity & 0.000 & 0.000 \\
\hline & Islam & 1.000 & 0.000 \\
\hline & Hinduism & 0.000 & 0.000 \\
\hline & Buddhism & 0.000 & 0.000 \\
\hline & Judaism & 0.000 & 0.000 \\
\hline & Other religion & 0.000 & 0.000 \\
\hline & Non-religious/Secular & 0.000 & 0.000 \\
\hline & Population size & $7,293,056$ & \\
\hline & Institutional quality & -3.00 & \\
\hline \multirow[t]{10}{*}{ Kazakhstan } & World religion (Big Five) & 0.980 & 0.150 \\
\hline & Christianity & 0.320 & 0.470 \\
\hline & Islam & 0.660 & 0.470 \\
\hline & Hinduism & 0.000 & 0.000 \\
\hline & Buddhism & 0.001 & 0.032 \\
\hline & Judaism & 0.000 & 0.000 \\
\hline & Other religion & 0.001 & 0.032 \\
\hline & Non-religious/Secular & 0.022 & 0.150 \\
\hline & Population size & $16,287,597$ & \\
\hline & Institutional quality & -6.00 & \\
\hline \multirow[t]{10}{*}{ Kenya } & World religion (Big Five) & 0.980 & 0.130 \\
\hline & Christianity & 0.910 & 0.280 \\
\hline & Islam & 0.067 & 0.250 \\
\hline & Hinduism & 0.001 & 0.032 \\
\hline & Buddhism & 0.000 & 0.000 \\
\hline & Judaism & 0.000 & 0.000 \\
\hline & Other religion & 0.006 & 0.077 \\
\hline & Non-religious/Secular & 0.012 & 0.110 \\
\hline & Population size & $42,049,224$ & \\
\hline & Institutional quality & 7.60 & \\
\hline \multirow[t]{10}{*}{ Lithuania } & World religion (Big Five) & 0.920 & 0.270 \\
\hline & Christianity & 0.920 & 0.270 \\
\hline & Islam & 0.000 & 0.000 \\
\hline & Hinduism & 0.000 & 0.000 \\
\hline & Buddhism & 0.000 & 0.000 \\
\hline & Judaism & 0.000 & 0.000 \\
\hline & Other religion & 0.000 & 0.000 \\
\hline & Non-religious/Secular & 0.080 & 0.270 \\
\hline & Population size & $3,094,864$ & \\
\hline & Institutional quality & 10.00 & \\
\hline
\end{tabular}




\begin{tabular}{|c|c|c|c|c|c|c|c|}
\hline Country & Variable & Mean & Std. dev. & Country & Variable & Mean & Std. dev. \\
\hline \multirow[t]{10}{*}{ Malawi } & World religion (Big Five) & 0.980 & 0.130 & Netherlands & World religion (Big Five) & 0.600 & 0.490 \\
\hline & Christianity & 0.870 & 0.340 & & Christianity & 0.560 & 0.500 \\
\hline & Islam & 0.110 & 0.320 & & Islam & 0.028 & 0.160 \\
\hline & Hinduism & 0.000 & 0.000 & & Hinduism & 0.008 & 0.087 \\
\hline & Buddhism & 0.000 & 0.000 & & Buddhism & 0.005 & 0.071 \\
\hline & Judaism & 0.000 & 0.000 & & Judaism & 0.000 & 0.000 \\
\hline & Other religion & 0.015 & 0.120 & & Other religion & 0.039 & 0.190 \\
\hline & Non-religious/Secular & 0.002 & 0.045 & & Non-religious/Secular & 0.360 & 0.480 \\
\hline & Population size & $14,550,755$ & & & Population size & $16,607,882$ & \\
\hline & Institutional quality & 6.00 & & & Institutional quality & 10.00 & \\
\hline \multirow[t]{10}{*}{ Mexico } & World religion (Big Five) & 1.000 & 0.055 & Nicaragua & World religion (Big Five) & 0.960 & 0.200 \\
\hline & Christianity & 1.000 & 0.055 & & Christianity & 0.960 & 0.200 \\
\hline & Islam & 0.000 & 0.000 & & Islam & 0.000 & 0.000 \\
\hline & Hinduism & 0.000 & 0.000 & & Hinduism & 0.000 & 0.000 \\
\hline & Buddhism & 0.000 & 0.000 & & Buddhism & 0.000 & 0.000 \\
\hline & Judaism & 0.000 & 0.000 & & Judaism & 0.000 & 0.000 \\
\hline & Other religion & 0.000 & 0.000 & & Other religion & 0.001 & 0.033 \\
\hline & Non-religious/Secular & 0.003 & 0.055 & & Non-religious/Secular & 0.041 & 0.200 \\
\hline & Population size & $114,068,352$ & & & Population size & $5,824,518$ & \\
\hline & Institutional quality & 8.00 & & & Institutional quality & 9.00 & \\
\hline \multirow[t]{10}{*}{ Moldova } & World religion (Big Five) & 0.980 & 0.130 & Nigeria & World religion (Big Five) & 0.990 & 0.089 \\
\hline & Christianity & 0.980 & 0.130 & & Christianity & 0.670 & 0.470 \\
\hline & Islam & 0.001 & 0.032 & & Islam & 0.320 & 0.460 \\
\hline & Hinduism & 0.000 & 0.000 & & Hinduism & 0.001 & 0.032 \\
\hline & Buddhism & 0.000 & 0.000 & & Buddhism & 0.000 & 0.000 \\
\hline & Judaism & 0.000 & 0.000 & & Judaism & 0.001 & 0.032 \\
\hline & Other religion & 0.001 & 0.032 & & Other religion & 0.008 & 0.089 \\
\hline & Non-religious/Secular & 0.015 & 0.120 & & Non-religious/Secular & 0.000 & 0.000 \\
\hline & Population size & $2,862,618$ & & & Population size & $158,626,320$ & \\
\hline & Institutional quality & 9.00 & & & Institutional quality & 4.00 & \\
\hline \multirow[t]{10}{*}{ Morocco } & World religion (Big Five) & 1.000 & 0.000 & Pakistan & World religion (Big Five) & 1.000 & 0.045 \\
\hline & Christianity & 0.000 & 0.000 & & Christianity & 0.043 & 0.200 \\
\hline & Islam & 1.000 & 0.000 & & Islam & 0.940 & 0.230 \\
\hline & Hinduism & 0.000 & 0.000 & & Hinduism & 0.013 & 0.110 \\
\hline & Buddhism & 0.000 & 0.000 & & Buddhism & 0.000 & 0.000 \\
\hline & Judaism & 0.000 & 0.000 & & Judaism & 0.000 & 0.000 \\
\hline & Other religion & 0.000 & 0.000 & & Other religion & 0.002 & 0.045 \\
\hline & Non-religious/Secular & 0.000 & 0.000 & & Non-religious/Secular & 0.000 & 0.000 \\
\hline & Population size & $32,366,608$ & & & Population size & $179,444,256$ & \\
\hline & Institutional quality & -5.20 & & & Institutional quality & 5.60 & \\
\hline
\end{tabular}




\begin{tabular}{|c|c|c|c|}
\hline Country & Variable & Mean & Std. dev. \\
\hline \multirow[t]{10}{*}{ Peru } & World religion (Big Five) & 0.990 & 0.110 \\
\hline & Christianity & 0.990 & 0.110 \\
\hline & Islam & 0.000 & 0.000 \\
\hline & Hinduism & 0.000 & 0.000 \\
\hline & Buddhism & 0.000 & 0.000 \\
\hline & Judaism & 0.001 & 0.032 \\
\hline & Other religion & 0.000 & 0.000 \\
\hline & Non-religious/Secular & 0.011 & 0.110 \\
\hline & Population size & $29,030,750$ & \\
\hline & Institutional quality & 9.00 & \\
\hline \multirow[t]{10}{*}{ Philippines } & World religion (Big Five) & 1.000 & 0.045 \\
\hline & Christianity & 0.950 & 0.210 \\
\hline & Islam & 0.046 & 0.210 \\
\hline & Hinduism & 0.000 & 0.000 \\
\hline & Buddhism & 0.000 & 0.000 \\
\hline & Judaism & 0.000 & 0.000 \\
\hline & Other religion & 0.001 & 0.032 \\
\hline & Non-religious/Secular & 0.001 & 0.032 \\
\hline & Population size & $94,013,120$ & \\
\hline & Institutional quality & 8.00 & \\
\hline \multirow[t]{10}{*}{ Poland } & World religion (Big Five) & 0.980 & 0.140 \\
\hline & Christianity & 0.980 & 0.150 \\
\hline & Islam & 0.000 & 0.000 \\
\hline & Hinduism & 0.000 & 0.000 \\
\hline & Buddhism & 0.001 & 0.033 \\
\hline & Judaism & 0.000 & 0.000 \\
\hline & Other religion & 0.001 & 0.033 \\
\hline & Non-religious/Secular & 0.020 & 0.140 \\
\hline & Population size & $38,089,316$ & \\
\hline & Institutional quality & 10.00 & \\
\hline \multirow[t]{10}{*}{ Portugal } & World religion (Big Five) & 0.880 & 0.320 \\
\hline & Christianity & 0.880 & 0.330 \\
\hline & Islam & 0.001 & 0.032 \\
\hline & Hinduism & 0.001 & 0.032 \\
\hline & Buddhism & 0.001 & 0.032 \\
\hline & Judaism & 0.000 & 0.000 \\
\hline & Other religion & 0.006 & 0.079 \\
\hline & Non-religious/Secular & 0.110 & 0.320 \\
\hline & Population size & $10,554,386$ & \\
\hline & Institutional quality & 10.00 & \\
\hline
\end{tabular}

\begin{tabular}{|c|c|c|c|}
\hline Country & Variable & Mean & Std. dev. \\
\hline \multirow[t]{10}{*}{ Romania } & World religion (Big Five) & 0.990 & 0.078 \\
\hline & Christianity & 0.990 & 0.095 \\
\hline & Islam & 0.003 & 0.055 \\
\hline & Hinduism & 0.000 & 0.000 \\
\hline & Buddhism & 0.000 & 0.000 \\
\hline & Judaism & 0.000 & 0.000 \\
\hline & Other religion & 0.000 & 0.000 \\
\hline & Non-religious/Secular & 0.006 & 0.078 \\
\hline & Population size & $20,271,560$ & \\
\hline & Institutional quality & 9.00 & \\
\hline \multirow[t]{10}{*}{ Russia } & World religion (Big Five) & 0.920 & 0.280 \\
\hline & Christianity & 0.870 & 0.340 \\
\hline & Islam & 0.033 & 0.180 \\
\hline & Hinduism & 0.000 & 0.000 \\
\hline & Buddhism & 0.017 & 0.130 \\
\hline & Judaism & 0.002 & 0.047 \\
\hline & Other religion & 0.019 & 0.140 \\
\hline & Non-religious/Secular & 0.064 & 0.240 \\
\hline & Population size & $142,907,936$ & \\
\hline & Institutional quality & 4.00 & \\
\hline \multirow[t]{10}{*}{ Rwanda } & World religion (Big Five) & 1.000 & 0.032 \\
\hline & Christianity & 0.970 & 0.170 \\
\hline & Islam & 0.027 & 0.160 \\
\hline & Hinduism & 0.000 & 0.000 \\
\hline & Buddhism & 0.000 & 0.000 \\
\hline & Judaism & 0.000 & 0.000 \\
\hline & Other religion & 0.000 & 0.000 \\
\hline & Non-religious/Secular & 0.001 & 0.032 \\
\hline & Population size & $10,037,930$ & \\
\hline & Institutional quality & -3.60 & \\
\hline \multirow[t]{10}{*}{ Saudi Arabia } & World religion (Big Five) & 1.000 & 0.000 \\
\hline & Christianity & 0.000 & 0.000 \\
\hline & Islam & 1.000 & 0.000 \\
\hline & Hinduism & 0.000 & 0.000 \\
\hline & Buddhism & 0.000 & 0.000 \\
\hline & Judaism & 0.000 & 0.000 \\
\hline & Other religion & 0.000 & 0.000 \\
\hline & Non-religious/Secular & 0.000 & 0.000 \\
\hline & Population size & $27,472,636$ & \\
\hline & Institutional quality & -10.00 & \\
\hline
\end{tabular}




\begin{tabular}{|c|c|c|c|}
\hline Country & Variable & Mean & Std. dev. \\
\hline \multirow[t]{10}{*}{ Serbia } & World religion (Big Five) & 0.980 & 0.140 \\
\hline & Christianity & 0.930 & 0.260 \\
\hline & Islam & 0.053 & 0.230 \\
\hline & Hinduism & 0.000 & 0.000 \\
\hline & Buddhism & 0.001 & 0.031 \\
\hline & Judaism & 0.000 & 0.000 \\
\hline & Other religion & 0.001 & 0.031 \\
\hline & Non-religious/Secular & 0.018 & 0.130 \\
\hline & Population size & $7,279,128$ & \\
\hline & Institutional quality & 8.00 & \\
\hline \multirow[t]{10}{*}{ South Africa } & World religion (Big Five) & 0.920 & 0.270 \\
\hline & Christianity & 0.870 & 0.330 \\
\hline & Islam & 0.042 & 0.200 \\
\hline & Hinduism & 0.008 & 0.090 \\
\hline & Buddhism & 0.002 & 0.045 \\
\hline & Judaism & 0.000 & 0.000 \\
\hline & Other religion & 0.066 & 0.250 \\
\hline & Non-religious/Secular & 0.010 & 0.100 \\
\hline & Population size & $51,262,324$ & \\
\hline & Institutional quality & 9.00 & \\
\hline \multirow[t]{10}{*}{ South Korea } & World religion (Big Five) & 0.580 & 0.490 \\
\hline & Christianity & 0.380 & 0.490 \\
\hline & Islam & 0.001 & 0.032 \\
\hline & Hinduism & 0.000 & 0.000 \\
\hline & Buddhism & 0.200 & 0.400 \\
\hline & Judaism & 0.000 & 0.000 \\
\hline & Other religion & 0.008 & 0.090 \\
\hline & Non-religious/Secular & 0.410 & 0.490 \\
\hline & Population size & $49,610,628$ & \\
\hline & Institutional quality & 8.00 & \\
\hline \multirow[t]{10}{*}{ Spain } & World religion (Big Five) & 0.790 & 0.410 \\
\hline & Christianity & 0.780 & 0.420 \\
\hline & Islam & 0.011 & 0.110 \\
\hline & Hinduism & 0.000 & 0.000 \\
\hline & Buddhism & 0.001 & 0.032 \\
\hline & Judaism & 0.000 & 0.000 \\
\hline & Other religion & 0.004 & 0.064 \\
\hline & Non-religious/Secular & 0.210 & 0.410 \\
\hline & Population size & $46,481,940$ & \\
\hline & Institutional quality & 10.00 & \\
\hline
\end{tabular}

\begin{tabular}{|c|c|c|c|}
\hline Country & Variable & Mean & Std. dev. \\
\hline \multirow[t]{10}{*}{ Sri Lanka } & World religion (Big Five) & 1.000 & 0.000 \\
\hline & Christianity & 0.069 & 0.250 \\
\hline & Islam & 0.110 & 0.310 \\
\hline & Hinduism & 0.110 & 0.310 \\
\hline & Buddhism & 0.720 & 0.450 \\
\hline & Judaism & 0.000 & 0.000 \\
\hline & Other religion & 0.000 & 0.000 \\
\hline & Non-religious/Secular & 0.000 & 0.000 \\
\hline & Population size & $20,238,580$ & \\
\hline & Institutional quality & 4.00 & \\
\hline \multirow[t]{10}{*}{ Suriname } & World religion (Big Five) & 0.940 & 0.240 \\
\hline & Christianity & 0.520 & 0.500 \\
\hline & Islam & 0.140 & 0.350 \\
\hline & Hinduism & 0.280 & 0.450 \\
\hline & Buddhism & 0.000 & 0.000 \\
\hline & Judaism & 0.000 & 0.000 \\
\hline & Other religion & 0.024 & 0.150 \\
\hline & Non-religious/Secular & 0.034 & 0.180 \\
\hline & Population size & 529,158 & \\
\hline & Institutional quality & 5.00 & \\
\hline \multirow[t]{10}{*}{ Sweden } & World religion (Big Five) & 0.810 & 0.390 \\
\hline & Christianity & 0.790 & 0.410 \\
\hline & Islam & 0.015 & 0.120 \\
\hline & Hinduism & 0.000 & 0.000 \\
\hline & Buddhism & 0.003 & 0.058 \\
\hline & Judaism & 0.001 & 0.034 \\
\hline & Other religion & 0.010 & 0.100 \\
\hline & Non-religious/Secular & 0.180 & 0.390 \\
\hline & Population size & $9,372,973$ & \\
\hline & Institutional quality & 10.00 & \\
\hline \multirow[t]{10}{*}{ Switzerland } & World religion (Big Five) & 0.830 & 0.370 \\
\hline & Christianity & 0.810 & 0.390 \\
\hline & Islam & 0.014 & 0.120 \\
\hline & Hinduism & 0.002 & 0.046 \\
\hline & Buddhism & 0.002 & 0.046 \\
\hline & Judaism & 0.002 & 0.046 \\
\hline & Other religion & 0.011 & 0.100 \\
\hline & Non-religious/Secular & 0.160 & 0.360 \\
\hline & Population size & $7,825,135$ & \\
\hline & Institutional quality & 10.00 & \\
\hline
\end{tabular}




\begin{tabular}{|c|c|c|c|}
\hline Country & Variable & Mean & Std. dev. \\
\hline \multirow[t]{10}{*}{ Tanzania } & World religion (Big Five) & 1.000 & 0.032 \\
\hline & Christianity & 0.630 & 0.480 \\
\hline & Islam & 0.370 & 0.480 \\
\hline & Hinduism & 0.000 & 0.000 \\
\hline & Buddhism & 0.000 & 0.000 \\
\hline & Judaism & 0.000 & 0.000 \\
\hline & Other religion & 0.001 & 0.032 \\
\hline & Non-religious/Secular & 0.000 & 0.000 \\
\hline & Population size & $44,400,024$ & \\
\hline & Institutional quality & -1.00 & \\
\hline \multirow[t]{10}{*}{ Thailand } & World religion (Big Five) & 1.000 & 0.000 \\
\hline & Christianity & 0.002 & 0.045 \\
\hline & Islam & 0.055 & 0.230 \\
\hline & Hinduism & 0.000 & 0.000 \\
\hline & Buddhism & 0.940 & 0.230 \\
\hline & Judaism & 0.000 & 0.000 \\
\hline & Other religion & 0.000 & 0.000 \\
\hline & Non-religious/Secular & 0.000 & 0.000 \\
\hline & Population size & $67,189,440$ & \\
\hline & Institutional quality & 5.20 & \\
\hline \multirow[t]{10}{*}{ Turkey } & World religion (Big Five) & 0.980 & 0.140 \\
\hline & Christianity & 0.001 & 0.032 \\
\hline & Islam & 0.980 & 0.140 \\
\hline & Hinduism & 0.000 & 0.000 \\
\hline & Buddhism & 0.000 & 0.000 \\
\hline & Judaism & 0.000 & 0.000 \\
\hline & Other religion & 0.007 & 0.084 \\
\hline & Non-religious/Secular & 0.012 & 0.110 \\
\hline & Population size & $72,432,776$ & \\
\hline & Institutional quality & 7.80 & \\
\hline \multirow[t]{10}{*}{ Uganda } & World religion (Big Five) & 0.990 & 0.083 \\
\hline & Christianity & 0.810 & 0.390 \\
\hline & Islam & 0.180 & 0.380 \\
\hline & Hinduism & 0.001 & 0.032 \\
\hline & Buddhism & 0.001 & 0.032 \\
\hline & Judaism & 0.000 & 0.000 \\
\hline & Other religion & 0.006 & 0.077 \\
\hline & Non-religious/Secular & 0.001 & 0.032 \\
\hline & Population size & $32,461,418$ & \\
\hline & Institutional quality & -1.00 & \\
\hline
\end{tabular}

\begin{tabular}{|c|c|c|c|}
\hline Country & Variable & Mean & Std. dev. \\
\hline \multirow{10}{*}{ Ukraine } & World religion (Big Five) & 0.970 & 0.170 \\
\hline & Christianity & 0.960 & 0.200 \\
\hline & Islam & 0.010 & 0.097 \\
\hline & Hinduism & 0.000 & 0.000 \\
\hline & Buddhism & 0.000 & 0.000 \\
\hline & Judaism & 0.001 & 0.032 \\
\hline & Other religion & 0.001 & 0.032 \\
\hline & Non-religious/Secular & 0.029 & 0.170 \\
\hline & Population size & $45,896,320$ & \\
\hline & Institutional quality & 6.40 & \\
\hline \multirow{10}{*}{$\begin{array}{l}\text { United Arab } \\
\text { Emirates }\end{array}$} & World religion (Big Five) & 1000 & 0000 \\
\hline & Christianity & 0.000 & 0.000 \\
\hline & Islam & 1.000 & 0.000 \\
\hline & Hinduism & 0.000 & 0.000 \\
\hline & Buddhism & 0.000 & 0.000 \\
\hline & Judaism & 0.000 & 0.000 \\
\hline & Other religion & 0.000 & 0.000 \\
\hline & Non-religious/Secular & 0.000 & 0.000 \\
\hline & Population size & $8,329,044$ & \\
\hline & Institutional quality & -8.00 & \\
\hline \multirow[t]{10}{*}{ United Kingdom } & World religion (Big Five) & 0.680 & 0.470 \\
\hline & Christianity & 0.650 & 0.480 \\
\hline & Islam & 0.019 & 0.140 \\
\hline & Hinduism & 0.007 & 0.084 \\
\hline & Buddhism & 0.003 & 0.055 \\
\hline & Judaism & 0.003 & 0.055 \\
\hline & Other religion & 0.120 & 0.330 \\
\hline & Non-religious/Secular & 0.200 & 0.400 \\
\hline & Population size & $62,761,732$ & \\
\hline & Institutional quality & 10.00 & \\
\hline \multirow[t]{9}{*}{ United States } & World religion (Big Five) & 0.840 & 0.370 \\
\hline & Christianity & 0.800 & 0.400 \\
\hline & Islam & 0.008 & 0.089 \\
\hline & Hinduism & 0.001 & 0.032 \\
\hline & Buddhism & 0.006 & 0.077 \\
\hline & Judaism & 0.020 & 0.140 \\
\hline & Other religion & 0.022 & 0.150 \\
\hline & Non-religious/Secular & 0.140 & 0.350 \\
\hline & Population size & $309,115,008$ & \\
\hline
\end{tabular}




\begin{tabular}{llrr}
\hline Country & \multicolumn{1}{c}{ Variable } & Mean & Std. dev. \\
\hline \multirow{3}{*}{ Venezuela } & Institutional quality & 10.00 & \\
& & & 0.180 \\
& World religion (Big Five) & & 0.200 \\
& Christianity & 0.960 & 0.078 \\
& Islam & 0.006 & 0.000 \\
& Hinduism & 0.000 & 0.000 \\
& Buddhism & 0.000 & 0.000 \\
& Judaism & 0.000 & 0.089 \\
& Other religion & 0.008 & 0.160 \\
Non-religious/Secular & 0.026 & \\
& Population size & $28,471,520$ & \\
& Institutional quality & -1.40 & \\
& & & \\
& World religion (Big Five) & 0.380 & 0.490 \\
& Christianity & 0.099 & 0.300 \\
Vietnam & Islam & 0.000 & 0.000 \\
& Hinduism & 0.000 & 0.000
\end{tabular}

\begin{tabular}{llrr}
\hline Country & \multicolumn{1}{c}{ Variable } & \multicolumn{1}{c}{ Mean } & \multicolumn{1}{c}{ Std. dev. } \\
\hline & Buddhism & 0.280 & 0.450 \\
Judaism & 0.000 & 0.000 \\
Other religion & 0.033 & 0.180 \\
Non-religious/Secular & 0.580 & 0.490 \\
Population size & $87,995,472$ & \\
Institutional quality & -7.00 & \\
& & \\
Zimbabwe & 0.950 & 0.220 \\
& World religion (Big Five) & 0.940 & 0.240 \\
& Christianity & 0.009 & 0.095 \\
& Islam & 0.000 & 0.000 \\
& Hinduism & 0.000 & 0.000 \\
& Buddhism & 0.001 & 0.032 \\
& Judaism & 0.034 & 0.180 \\
Other religion & 0.016 & 0.130 \\
& Non-religious/Secular & $12,722,737$ & \\
Population size & 0.00 &
\end{tabular}

Tab S1. Summary statistics of religion, population size and institutional quality broken down by country. 


\begin{tabular}{lcccc}
\hline & $(1)$ & $(2)$ & $(3)$ & $(4)$ \\
& $\begin{array}{c}\text { Negative } \\
\text { reciprocity }\end{array}$ & $\begin{array}{c}\text { Positive } \\
\text { reciprocity }\end{array}$ & Altruism & Trust \\
\hline World religion (Big 5) & $-0.092^{* * *}$ & 0.006 & $0.145^{* * *}$ & $0.114^{* * *}$ \\
& $(0.021)$ & $(0.021)$ & $(0.021)$ & $(0.014)$ \\
Other religion & -0.035 & 0.015 & $0.157^{* *}$ & 0.043 \\
Age & $(0.054)$ & $(0.057)$ & $(0.049)$ & $(0.071)$ \\
Age squared & $-0.408^{*}$ & $0.805^{* * *}$ & -0.169 & 0.297 \\
& $(0.198)$ & $(0.169)$ & $(0.148)$ & $(0.190)$ \\
1 if female & $-0.389^{+}$ & $-0.830^{* * *}$ & 0.236 & 0.052 \\
& $(0.197)$ & $(0.178)$ & $(0.159)$ & $(0.187)$ \\
Subj. math skills & $-0.123^{* * *}$ & $0.055^{* * *}$ & $0.098^{* * *}$ & $0.058^{* * *}$ \\
Income bracket & $(0.012)$ & $(0.011)$ & $(0.014)$ & $(0.015)$ \\
& $0.039^{* * *}$ & $0.032^{* * *}$ & $0.037^{* * *}$ & $0.059^{* * *}$ \\
Education level & $(0.004)$ & $(0.003)$ & $(0.003)$ & $(0.003)$ \\
& $0.005^{* *}$ & $0.012^{* * *}$ & $0.010^{* * *}$ & -0.001 \\
Constant & $(0.002)$ & $(0.002)$ & $(0.001)$ & $(0.001)$ \\
& -0.000 & $0.071^{* * *}$ & $0.076^{* * *}$ & $-0.039^{* *}$ \\
\hline Country FE & $(0.010)$ & $(0.012)$ & $(0.012)$ & $(0.012)$ \\
Pseudo-R2 & $0.420^{* * *}$ & $-0.255^{* * *}$ & $-0.364^{* * *}$ & $-0.118^{* *}$ \\
Observations & $(0.053)$ & $(0.050)$ & $(0.038)$ & $(0.040)$ \\
\hline
\end{tabular}

Tab. S2. Differences in social preferences between religious and non-religious people. Main results.

Coefficients are based on OLS regressions. Positive values indicate that religious people exhibited higher levels of the respective preference, negative values indicate that religious people exhibited lower levels of the respective preference. The difference between members of world religions and non-religious people was calculated as the coefficient on a categorical variable that takes on the value 0 if respondent is non-religious (reference group), 1 if respondent is Christian, 2 if respondent is Muslim, 3 if respondent is Hindu, 4 if respondent is Buddhist, 5 if respondent is Jewish and 6 if respondent belongs to a non-world religion (other religion). Specifications include the following control variables: gender, age, age squared, subjective math skills, education level, household income brackets, and country fixed effects. Standard errors clustered at the country level. $+=$ Statistical significance at the $10 \%$ level; $*=$ Statistical significance at the $5 \%$ level; $* *=$ Statistical significance at the $1 \%$ level; $* * *=$ Statistical significance at the $0.1 \%$ level. 


\begin{tabular}{|c|c|c|c|c|c|c|c|c|}
\hline & $\begin{array}{c}\text { (1) } \\
\text { Negative } \\
\text { reciprocity }\end{array}$ & $\begin{array}{c}(2) \\
\text { Negative } \\
\text { reciprocity }\end{array}$ & $\begin{array}{c}\text { (3) } \\
\text { Positive } \\
\text { reciprocity }\end{array}$ & $\begin{array}{c}\text { (4) } \\
\text { Positive } \\
\text { reciprocity }\end{array}$ & $\begin{array}{c}\text { (5) } \\
\text { Altruism }\end{array}$ & $\begin{array}{c}(6) \\
\text { Altruism }\end{array}$ & $\begin{array}{c}(7) \\
\text { Trust }\end{array}$ & $\begin{array}{c}(8) \\
\text { Trust }\end{array}$ \\
\hline World religion (Big 5) & $\begin{array}{c}-0.164^{* * *} \\
(0.024)\end{array}$ & $\begin{array}{c}-0.093^{* * *} \\
(0.021)\end{array}$ & $\begin{array}{l}-0.009 \\
(0.022)\end{array}$ & $\begin{array}{c}0.000 \\
(0.021)\end{array}$ & $\begin{array}{c}0.140^{* * *} \\
(0.022)\end{array}$ & $\begin{array}{c}0.140^{* * *} \\
(0.022)\end{array}$ & $\begin{array}{c}0.137^{* * *} \\
(0.016)\end{array}$ & $\begin{array}{c}0.118^{* * *} \\
(0.016)\end{array}$ \\
\hline Other religion & $\begin{array}{l}-0.115^{*} \\
(0.058)\end{array}$ & $\begin{array}{l}-0.057 \\
(0.057)\end{array}$ & $\begin{array}{l}-0.007 \\
(0.058)\end{array}$ & $\begin{array}{c}0.001 \\
(0.059)\end{array}$ & $\begin{array}{c}0.142^{* * *} \\
(0.051)\end{array}$ & $\begin{array}{c}0.144^{* * *} \\
(0.051)\end{array}$ & $\begin{array}{c}0.042 \\
(0.072)\end{array}$ & $\begin{array}{c}0.027 \\
(0.073)\end{array}$ \\
\hline Age & & $\begin{array}{c}-0.407^{* *} \\
(0.192)\end{array}$ & & $\begin{array}{l}0.944^{* * *} \\
(0.192)\end{array}$ & & $\begin{array}{l}-0.046 \\
(0.147)\end{array}$ & & $\begin{array}{c}0.169 \\
(0.191)\end{array}$ \\
\hline Age squared & & $\begin{array}{c}-0.492^{* *} \\
(0.193)\end{array}$ & & $\begin{array}{c}-1.159^{* * *} \\
(0.196)\end{array}$ & & $\begin{array}{l}-0.084 \\
(0.153)\end{array}$ & & $\begin{array}{c}0.106 \\
(0.183)\end{array}$ \\
\hline 1 if female & & $\begin{array}{c}-0.152^{* * *} \\
(0.011)\end{array}$ & & $\begin{array}{l}0.023^{* *} \\
(0.011)\end{array}$ & & $\begin{array}{c}0.064^{* * *} \\
(0.013)\end{array}$ & & $\begin{array}{c}0.022 \\
(0.014)\end{array}$ \\
\hline Constant & $\begin{array}{c}0.498^{* * *} \\
(0.024)\end{array}$ & $\begin{array}{c}0.674^{* * *} \\
(0.042)\end{array}$ & $\begin{array}{c}0.308^{* * *} \\
(0.022)\end{array}$ & $\begin{array}{c}0.124^{* * *} \\
(0.046)\end{array}$ & $\begin{array}{c}0.038^{*} \\
(0.022)\end{array}$ & $\begin{array}{c}0.029 \\
(0.035) \\
\end{array}$ & $\begin{array}{c}0.181^{* * *} \\
(0.016)\end{array}$ & $\begin{array}{c}0.128^{* * *} \\
(0.042)\end{array}$ \\
\hline Country FE & Yes & Yes & Yes & Yes & Yes & Yes & Yes & Yes \\
\hline Pseudo-R2 & 0.08 & 0.10 & 0.11 & 0.11 & 0.12 & 0.12 & 0.08 & 0.08 \\
\hline Observations & 73985 & 73802 & 75451 & 75262 & 75182 & 74997 & 74180 & 74001 \\
\hline
\end{tabular}

Tab. S3. Differences in social preferences between religious and non-religious people. Alternative specifications.

Coefficients are based on OLS regressions. Positive values indicate that religious people exhibited higher levels of the respective preference, negative values indicate that religious people exhibited lower levels of the respective preference. The difference between members of world religions and nonreligious people was calculated as the coefficient on a categorical variable that takes on the value 0 if respondent is non-religious (reference group), 1 if respondent is Christian, 2 if respondent is Muslim, 3 if respondent is Hindu, 4 if respondent is Buddhist, 5 if respondent is Jewish and 6 if respondent belongs to a non-world religion (other religion). Columns (1), (3), (5) and (7) show estimates on an unconditional model (no controls except of country fixed effects). Columns (2), (4), (6) and (8) show estimates of a model with exogenous individual controls (i.e., gender, age, age squared) and country fixed effects. Standard errors clustered at the country level. + = Statistical significance at the $10 \%$ level; * = Statistical significance at the 5\% level; $* *=$ Statistical significance at the $1 \%$ level $; * * *=$ Statistical significance at the $0.1 \%$ level. 


\begin{tabular}{|c|c|c|c|c|c|c|c|c|}
\hline & $\begin{array}{c}\text { (1) } \\
\text { Negative } \\
\text { reciprocity }\end{array}$ & $\begin{array}{c}(2) \\
\text { Negative } \\
\text { reciprocity }\end{array}$ & $\begin{array}{c}(3) \\
\text { Positive } \\
\text { reciprocity }\end{array}$ & $\begin{array}{c}(4) \\
\text { Positive } \\
\text { reciprocity }\end{array}$ & $\begin{array}{c}(5) \\
\text { Altruism }\end{array}$ & $\begin{array}{c}(6) \\
\text { Altruism }\end{array}$ & $\begin{array}{l}(7) \\
\text { Trust }\end{array}$ & $\begin{array}{l}(8) \\
\text { Trust }\end{array}$ \\
\hline World religion (Big 5) & $\begin{array}{c}-0.091^{* * *} \\
(0.021)\end{array}$ & $\begin{array}{c}-0.086^{* * *} \\
(0.028)\end{array}$ & $\begin{array}{c}0.007 \\
(0.021)\end{array}$ & $\begin{array}{l}-0.060^{* * *} \\
(0.027)\end{array}$ & $\begin{array}{c}0.146^{* * *} \\
(0.022)\end{array}$ & $\begin{array}{l}0.061^{* *} \\
(0.029)\end{array}$ & $\begin{array}{c}0.115^{* * *} \\
(0.014)\end{array}$ & $\begin{array}{c}0.076^{* * *} \\
(0.021)\end{array}$ \\
\hline Other religion & $\begin{array}{l}-0.034 \\
(0.054)\end{array}$ & $\begin{array}{l}-0.005 \\
(0.060)\end{array}$ & $\begin{array}{c}0.016 \\
(0.057)\end{array}$ & $\begin{array}{l}-0.050 \\
(0.065)\end{array}$ & $\begin{array}{c}0.158^{* * *} \\
(0.049)\end{array}$ & $\begin{array}{l}0.098^{*} \\
(0.052)\end{array}$ & $\begin{array}{c}0.044 \\
(0.071)\end{array}$ & $\begin{array}{l}-0.018 \\
(0.087)\end{array}$ \\
\hline Age & $\begin{array}{l}-0.395^{*} \\
(0.204)\end{array}$ & $\begin{array}{l}-0.308 \\
(0.204)\end{array}$ & $\begin{array}{c}0.784^{* * *} \\
(0.173)\end{array}$ & $\begin{array}{c}0.729^{* * *} \\
(0.188)\end{array}$ & $\begin{array}{l}-0.208 \\
(0.151)\end{array}$ & $\begin{array}{l}-0.171 \\
(0.144)\end{array}$ & $\begin{array}{c}0.285 \\
(0.201)\end{array}$ & $\begin{array}{c}0.158 \\
(0.163)\end{array}$ \\
\hline Age squared & $\begin{array}{l}-0.400^{*} \\
(0.203)\end{array}$ & $\begin{array}{c}-0.490^{* * *} \\
(0.210)\end{array}$ & $\begin{array}{c}-0.816^{* * *} \\
(0.183)\end{array}$ & $\begin{array}{c}-0.793^{* * *} \\
(0.203)\end{array}$ & $\begin{array}{c}0.266 \\
(0.162)\end{array}$ & $\begin{array}{c}0.123 \\
(0.151)\end{array}$ & $\begin{array}{c}0.056 \\
(0.197)\end{array}$ & $\begin{array}{c}0.121 \\
(0.173)\end{array}$ \\
\hline 1 if female & $\begin{array}{c}-0.126^{* * *} \\
(0.012)\end{array}$ & $\begin{array}{c}-0.119^{* * *} \\
(0.013)\end{array}$ & $\begin{array}{c}0.053^{* * *} \\
(0.012)\end{array}$ & $\begin{array}{c}0.060^{* * * *} \\
(0.013)\end{array}$ & $\begin{array}{c}0.103^{* * *} \\
(0.014)\end{array}$ & $\begin{array}{c}0.104^{* * *} \\
(0.014)\end{array}$ & $\begin{array}{c}0.053^{* * *} \\
(0.016)\end{array}$ & $\begin{array}{c}0.054^{* * *} \\
(0.016)\end{array}$ \\
\hline Subj. math skills & $\begin{array}{l}0.039^{* * *} \\
(0.004)\end{array}$ & $\begin{array}{c}0.040^{* * *} \\
(0.005)\end{array}$ & $\begin{array}{c}0.031^{* * *} \\
(0.003)\end{array}$ & $\begin{array}{l}0.032^{* * * *} \\
(0.003)\end{array}$ & $\begin{array}{c}0.036^{* * *} \\
(0.003)\end{array}$ & $\begin{array}{c}0.038^{* * *} \\
(0.003)\end{array}$ & $\begin{array}{c}0.058^{* * *} \\
(0.003)\end{array}$ & $\begin{array}{c}0.059^{* * *} \\
(0.002)\end{array}$ \\
\hline Income bracket & $\begin{array}{l}0.006^{* * *} \\
(0.002)\end{array}$ & $\begin{array}{l}0.006^{* * *} \\
(0.002)\end{array}$ & $\begin{array}{l}0.013^{* * *} \\
(0.002)\end{array}$ & $\begin{array}{c}0.012^{* * *} \\
(0.002)\end{array}$ & $\begin{array}{c}0.011^{* * * *} \\
(0.001)\end{array}$ & $\begin{array}{l}0.011^{* * *} \\
(0.002)\end{array}$ & $\begin{array}{l}-0.001 \\
(0.001)\end{array}$ & $\begin{array}{l}-0.000 \\
(0.001)\end{array}$ \\
\hline Education level & $\begin{array}{c}0.004 \\
(0.010)\end{array}$ & $\begin{array}{l}-0.005 \\
(0.009)\end{array}$ & $\begin{array}{l}0.076^{* * *} \\
(0.011)\end{array}$ & $\begin{array}{c}0.080^{* * *} \\
(0.013)\end{array}$ & $\begin{array}{c}0.081^{* * *} \\
(0.012)\end{array}$ & $\begin{array}{c}0.089^{* * *} \\
(0.012)\end{array}$ & $\begin{array}{c}-0.038^{* * * *} \\
(0.012)\end{array}$ & $\begin{array}{c}-0.032^{* *} \\
(0.013)\end{array}$ \\
\hline $\begin{array}{l}\text { WP119 Religion } \\
\text { Important }\end{array}$ & & $\begin{array}{c}-0.070^{* * *} \\
(0.017)\end{array}$ & & $\begin{array}{c}0.094^{* * *} \\
(0.026)\end{array}$ & & $\begin{array}{c}0.174^{* * *} \\
(0.018)\end{array}$ & & $\begin{array}{c}0.089^{* * *} \\
(0.024)\end{array}$ \\
\hline Constant & $\begin{array}{c}0.409^{* * *} \\
(0.055)\end{array}$ & $\begin{array}{c}0.459^{* * *} \\
(0.062)\end{array}$ & $\begin{array}{c}-0.257^{* * *} \\
(0.051)\end{array}$ & $\begin{array}{c}-0.276^{* * *} \\
(0.058)\end{array}$ & $\begin{array}{c}-0.361^{* * *} \\
(0.038)\end{array}$ & $\begin{array}{c}-0.468^{* * *} \\
(0.046)\end{array}$ & $\begin{array}{c}-0.110^{* * *} \\
(0.040)\end{array}$ & $\begin{array}{c}-0.149^{* * *} \\
(0.049)\end{array}$ \\
\hline Country FE & Yes & Yes & Yes & Yes & Yes & Yes & Yes & Yes \\
\hline Pseudo-R2 & 0.11 & 0.11 & 0.13 & 0.13 & 0.13 & 0.13 & 0.10 & 0.10 \\
\hline Observations & 68871 & 56031 & 70038 & 56963 & 69825 & 56785 & 69116 & 56230 \\
\hline
\end{tabular}

Tab. S4. Differences in social preferences between religious and non-religious people. Excluding countries from the sample and controlling for religiosity.

Coefficients are based on OLS regressions (for further notes see Tab. S2 and S3). Columns (1), (3), (5) and (7) show models with a sample that excludes the following Muslim countries: Saudi Arabia, Jordan, United Arab Emirates and Egypt (see Extended Methods and Data above). Columns (2), (4), (6) and (8) show a model that accounts for religiosity by adding a binary control variable that takes the value of 0 if religion is not important in a respondent's daily life, and 1 if religion is important in daily life. Specifications include the following control variables: gender, age, age squared, subjective math skills, education level, household income brackets, and country fixed effects. Standard errors clustered at the country level. $+=$ Statistical significance at the $10 \%$ level; $*=$ Statistical significance at the $5 \%$ level; $* *=$ Statistical significance at the $1 \%$ level; $* * *=$ Statistical significance at the $0.1 \%$ level. 


\begin{tabular}{|c|c|c|c|c|c|}
\hline & $\begin{array}{c}1) \\
\text { Prosocial } \\
\text { Index }\end{array}$ & $\begin{array}{c}(2) \\
\text { Prosocial } \\
\text { Index }\end{array}$ & $\begin{array}{c}(3) \\
\text { Prosocial } \\
\text { Index }\end{array}$ & $\begin{array}{c}(4) \\
\text { Prosocial } \\
\text { Index I }\end{array}$ & $\begin{array}{c}(5) \\
\text { Prosocial } \\
\text { Index II }\end{array}$ \\
\hline Christianity & $\begin{array}{c}0.136^{* * *} \\
(0.018)\end{array}$ & $\begin{array}{c}0.133^{* * *} \\
(0.018)\end{array}$ & $\begin{array}{c}0.138^{* * *} \\
(0.018)\end{array}$ & $\begin{array}{c}0.178^{* * *} \\
(0.016)\end{array}$ & $\begin{array}{c}0.125^{* * *} \\
(0.018)\end{array}$ \\
\hline Islam & $\begin{array}{c}0.214^{* * *} \\
(0.028)\end{array}$ & $\begin{array}{c}0.211^{* * *} \\
(0.028)\end{array}$ & $\begin{array}{c}0.236^{* * *} \\
(0.028)\end{array}$ & $\begin{array}{c}0.285^{* * *} \\
(0.025)\end{array}$ & $\begin{array}{c}0.219^{* * *} \\
(0.028)\end{array}$ \\
\hline Hinduism & $\begin{array}{l}0.182^{* * *} \\
(0.045)\end{array}$ & $\begin{array}{c}0.181^{* * *} \\
(0.045)\end{array}$ & $\begin{array}{c}0.193^{* * *} \\
(0.045)\end{array}$ & $\begin{array}{c}0.233^{* * *} \\
(0.041)\end{array}$ & $\begin{array}{c}0.174^{* * *} \\
(0.045)\end{array}$ \\
\hline Buddhism & $\begin{array}{c}0.193^{* * *} \\
(0.040)\end{array}$ & $\begin{array}{c}0.191^{* * *} \\
(0.040)\end{array}$ & $\begin{array}{c}0.192^{* * *} \\
(0.040)\end{array}$ & $\begin{array}{c}0.200^{* * *} \\
(0.036)\end{array}$ & $\begin{array}{c}0.186^{* * *} \\
(0.040)\end{array}$ \\
\hline Judaism & $\begin{array}{c}0.277^{* * *} \\
(0.077)\end{array}$ & $\begin{array}{c}0.277^{* * *} \\
(0.078)\end{array}$ & $\begin{array}{l}0.252^{* *} \\
(0.077)\end{array}$ & $\begin{array}{c}0.303^{* * *} \\
(0.069)\end{array}$ & $\begin{array}{c}0.273^{* * *} \\
(0.077)\end{array}$ \\
\hline Other religion & $\begin{array}{c}0.110^{*} \\
(0.044)\end{array}$ & $\begin{array}{c}0.109^{*} \\
(0.044)\end{array}$ & $\begin{array}{l}0.137^{* *} \\
(0.043)\end{array}$ & $\begin{array}{l}0.151^{* * *} \\
(0.039)\end{array}$ & $\begin{array}{l}0.123^{* *} \\
(0.044)\end{array}$ \\
\hline Age & & $\begin{array}{c}0.659^{* * *} \\
(0.120)\end{array}$ & $\begin{array}{c}0.539^{* * *} \\
(0.119)\end{array}$ & $\begin{array}{c}0.100 \\
(0.108)\end{array}$ & $\begin{array}{c}0.488^{* * *} \\
(0.120)\end{array}$ \\
\hline Age squared & & $\begin{array}{c}-0.757^{* * *} \\
(0.128)\end{array}$ & $\begin{array}{c}-0.357^{* *} \\
(0.128)\end{array}$ & $\begin{array}{c}0.205^{+} \\
(0.116)\end{array}$ & $\begin{array}{c}-0.421^{* *} \\
(0.130)\end{array}$ \\
\hline 1 if female & & $\begin{array}{c}0.066^{* * *} \\
(0.008)\end{array}$ & $\begin{array}{c}0.123^{* * *} \\
(0.008)\end{array}$ & $\begin{array}{c}0.111^{* * *} \\
(0.007)\end{array}$ & $\begin{array}{c}0.104^{* * *} \\
(0.008)\end{array}$ \\
\hline Subj. math skills & & & $\begin{array}{c}0.069^{* * *} \\
(0.002)\end{array}$ & $\begin{array}{c}0.068^{* * *} \\
(0.001)\end{array}$ & $\begin{array}{c}0.074^{* * *} \\
(0.002)\end{array}$ \\
\hline Income bracket & & & $\begin{array}{l}0.014^{* * *} \\
(0.001)\end{array}$ & $\begin{array}{l}0.007^{* * *} \\
(0.001)\end{array}$ & $\begin{array}{l}0.015^{* * *} \\
(0.001)\end{array}$ \\
\hline Education level & & & $\begin{array}{c}0.081^{* * *} \\
(0.007)\end{array}$ & $\begin{array}{c}0.030^{* * *} \\
(0.007)\end{array}$ & $\begin{array}{c}0.081^{* * *} \\
(0.008)\end{array}$ \\
\hline Constant & $\begin{array}{l}0.231^{* * *} \\
(0.045)\end{array}$ & $\begin{array}{c}0.082 \\
(0.051)\end{array}$ & $\begin{array}{c}-0.540^{* * *} \\
(0.052)\end{array}$ & $\begin{array}{c}-0.446^{* * *} \\
(0.047)\end{array}$ & $\begin{array}{c}-0.469^{* * *} \\
(0.053)\end{array}$ \\
\hline \multicolumn{6}{|c|}{ Wald test of equality of coefficients } \\
\hline Christianity vs. Islam & $\begin{array}{l}0.078^{* * *} \\
(0.022)\end{array}$ & $\begin{array}{c}0.078^{* * *} \\
(0.022)\end{array}$ & $\begin{array}{c}0.098^{* * *} \\
(0.022)\end{array}$ & $\begin{array}{l}0.107^{* * *} \\
(0.020)\end{array}$ & $\begin{array}{c}0.094^{* * *} \\
(0.022)\end{array}$ \\
\hline Christianity vs. Hinduism & $\begin{array}{c}0.046 \\
(0.043)\end{array}$ & $\begin{array}{c}0.048 \\
(0.043)\end{array}$ & $\begin{array}{c}0.055 \\
(0.042)\end{array}$ & $\begin{array}{c}0.055 \\
(0.038)\end{array}$ & $\begin{array}{c}0.049 \\
(0.043)\end{array}$ \\
\hline Christianity vs. Buddhism & $\begin{array}{c}0.057 \\
(0.040)\end{array}$ & $\begin{array}{c}0.058 \\
(0.040)\end{array}$ & $\begin{array}{c}0.054 \\
(0.040)\end{array}$ & $\begin{array}{c}0.022 \\
(0.036)\end{array}$ & $\begin{array}{c}0.060 \\
(0.040)\end{array}$ \\
\hline Christianity vs. Judaism & $\begin{array}{c}0.141^{+} \\
(0.076)\end{array}$ & $\begin{array}{c}0.144^{+} \\
(0.076)\end{array}$ & $\begin{array}{c}0.114 \\
(0.075)\end{array}$ & $\begin{array}{c}0.126^{+} \\
(0.068)\end{array}$ & $\begin{array}{c}0.148^{+} \\
(0.076)\end{array}$ \\
\hline Islam vs. Hinduism & $\begin{array}{c}0.032 \\
(0.041)\end{array}$ & $\begin{array}{c}0.030 \\
(0.041)\end{array}$ & $\begin{array}{c}0.043 \\
(0.041)\end{array}$ & $\begin{array}{c}0.052 \\
(0.037)\end{array}$ & $\begin{array}{c}0.045 \\
(0.041)\end{array}$ \\
\hline Islam vs. Buddhism & $\begin{array}{c}0.021 \\
(0.043)\end{array}$ & $\begin{array}{c}0.020 \\
(0.043)\end{array}$ & $\begin{array}{c}0.044 \\
(0.042)\end{array}$ & $\begin{array}{c}0.085^{*} \\
(0.038)\end{array}$ & $\begin{array}{c}0.034 \\
(0.043)\end{array}$ \\
\hline Islam vs. Judaism & $\begin{array}{c}0.063 \\
(0.075)\end{array}$ & $\begin{array}{c}0.066 \\
(0.076)\end{array}$ & $\begin{array}{c}0.016 \\
(0.075)\end{array}$ & $\begin{array}{c}0.018 \\
(0.068)\end{array}$ & $\begin{array}{c}0.054 \\
(0.076)\end{array}$ \\
\hline Hinduism vs. Buddhism & 0.011 & 0.010 & 0.001 & 0.033 & 0.011 \\
\hline
\end{tabular}




\begin{tabular}{lccccc} 
& $(0.054)$ & $(0.054)$ & $(0.053)$ & $(0.048)$ & $(0.054)$ \\
Hinduism vs. Judaism & 0.095 & 0.096 & 0.059 & 0.070 & 0.098 \\
& $(0.085)$ & $(0.085)$ & $(0.084)$ & $(0.076)$ & $(0.085)$ \\
Buddhism vs. Judaism & 0.084 & 0.086 & 0.060 & 0.103 & 0.087 \\
& $(0.084)$ & $(0.085)$ & $(0.084)$ & $(0.076)$ & $(0.085)$ \\
\hline Country FE & Yes & Yes & Yes & Yes & Yes \\
Pseudo-R2 & 0.14 & 0.15 & 0.18 & 0.14 & 0.18 \\
Observations & 73895 & 73718 & 72888 & 72918 & 71955 \\
\hline
\end{tabular}

Tab. S5. Differences in prosocial preferences across world religions. Main results, alternative specifications and alternative measures of the prosocial preference index.

Coefficients are based on OLS regressions. The summary index of prosocial preferences is based on a principal component analysis of positive reciprocity, altruism and trust. Positive values indicate that members of world religions exhibited higher levels of prosocial preferences, negative values indicate that members of world religions exhibited lower levels of prosocial preferences. The difference between members of world religions and non-religious people was calculated as the coefficient on a categorical variable that takes on the value 0 if respondent is non-religious (reference group), 1 if respondent is Christian, 2 if respondent is Muslim, 3 if respondent is Hindu, 4 if respondent is Buddhist, 5 if respondent is Jewish and 6 if respondent belongs to a non-world religion (other religion). Column (1) shows estimates on an unconditional model (no controls except of country fixed effects). Column (2) show estimates of a model with exogenous individual controls (i.e., gender, age, age squared) and country fixed effects. Column (3) shows estimates of the main specification that includes the following control variables: gender, age, age squared, subjective math skills, education level, household income brackets, and country fixed effects. Column (4) shows estimates of the main specification with an alternative measure of the prosocial preference index including altruism and trust, and Column (5) shows estimates of the main specification with an alternative measure of the prosocial preference index including negative reciprocity, positive reciprocity, altruism and trust. The Wald tests reported at the middle of the table are run on the null hypothesis that coefficients of the categorical variable identifying a religion are equal to each other (differences between coefficients are reported as absolute differences). Standard errors clustered at the country level. $+=$ Statistical significance at the $10 \%$ level; $*=$ Statistical significance at the $5 \%$ level; $* *=$ Statistical significance at the $1 \%$ level; *** = Statistical significance at the $0.1 \%$ level. 


\begin{tabular}{|c|c|c|c|c|c|c|c|}
\hline & $\begin{array}{c}\text { (1) } \\
\text { Negative } \\
\text { reciprocity }\end{array}$ & $\begin{array}{c}\text { (2) } \\
\text { Positive } \\
\text { reciprocity }\end{array}$ & $\begin{array}{c}\text { (3) } \\
\text { Altruism }\end{array}$ & $\begin{array}{c}\text { (4) } \\
\text { Trust }\end{array}$ & $\begin{array}{c}(5) \\
\text { Prosocial } \\
\text { Index }\end{array}$ & $\begin{array}{c}(6) \\
\text { Prosocial } \\
\text { Index I }\end{array}$ & $\begin{array}{c}(7) \\
\text { Prosocial } \\
\text { Index II } \\
\end{array}$ \\
\hline Christianity & $\begin{array}{l}-0.091^{* *} \\
(0.030)\end{array}$ & $\begin{array}{l}-0.063^{*} \\
(0.026)\end{array}$ & $\begin{array}{l}0.056^{+} \\
(0.029)\end{array}$ & $\begin{array}{l}0.079^{* *} \\
(0.023)\end{array}$ & $\begin{array}{c}0.029 \\
(0.035)\end{array}$ & $\begin{array}{l}0.095^{* *} \\
(0.032)\end{array}$ & $\begin{array}{c}0.018 \\
(0.033)\end{array}$ \\
\hline Islam & $\begin{array}{l}-0.082 \\
(0.056)\end{array}$ & $\begin{array}{l}-0.035 \\
(0.051)\end{array}$ & $\begin{array}{l}0.114^{*} \\
(0.053)\end{array}$ & $\begin{array}{l}0.158^{* *} \\
(0.050)\end{array}$ & $\begin{array}{c}0.118 \\
(0.071)\end{array}$ & $\begin{array}{l}0.190^{* * *} \\
(0.057)\end{array}$ & $\begin{array}{c}0.105 \\
(0.066)\end{array}$ \\
\hline Hinduism & $\begin{array}{l}-0.136^{*} \\
(0.056)\end{array}$ & $\begin{array}{l}-0.057 \\
(0.044)\end{array}$ & $\begin{array}{c}0.031 \\
(0.044)\end{array}$ & $\begin{array}{l}0.152^{* *} \\
(0.052)\end{array}$ & $\begin{array}{c}0.052 \\
(0.054)\end{array}$ & $\begin{array}{l}0.125^{* * *} \\
(0.044)\end{array}$ & $\begin{array}{c}0.039 \\
(0.052)\end{array}$ \\
\hline Buddhism & $\begin{array}{l}-0.046 \\
(0.041)\end{array}$ & $\begin{array}{l}-0.022 \\
(0.064)\end{array}$ & $\begin{array}{c}0.107^{*} \\
(0.049)\end{array}$ & $\begin{array}{l}-0.066 \\
(0.138)\end{array}$ & $\begin{array}{c}0.048 \\
(0.067)\end{array}$ & $\begin{array}{c}0.043 \\
(0.073)\end{array}$ & $\begin{array}{c}0.042 \\
(0.068)\end{array}$ \\
\hline Judaism & $\begin{array}{l}0.186^{* *} \\
(0.060)\end{array}$ & $\begin{array}{l}-0.046 \\
(0.049)\end{array}$ & $\begin{array}{c}0.247^{* * *} \\
(0.045)\end{array}$ & $\begin{array}{c}0.146^{* * *} \\
(0.040)\end{array}$ & $\begin{array}{l}0.191^{* * *} \\
(0.058)\end{array}$ & $\begin{array}{c}0.274^{* * *} \\
(0.049)\end{array}$ & $\begin{array}{c}0.212^{* * *} \\
(0.061)\end{array}$ \\
\hline Other religion & $\begin{array}{l}-0.007 \\
(0.058)\end{array}$ & $\begin{array}{l}-0.049 \\
(0.066)\end{array}$ & $\begin{array}{c}0.100^{+} \\
(0.051)\end{array}$ & $\begin{array}{c}-0.003 \\
(0.086)\end{array}$ & $\begin{array}{c}0.032 \\
(0.061)\end{array}$ & $\begin{array}{c}0.067 \\
(0.072)\end{array}$ & $\begin{array}{c}0.020 \\
(0.063)\end{array}$ \\
\hline Age & $\begin{array}{l}-0.308 \\
(0.204)\end{array}$ & $\begin{array}{c}0.728^{* * * *} \\
(0.188)\end{array}$ & $\begin{array}{l}-0.173 \\
(0.143)\end{array}$ & $\begin{array}{c}0.155 \\
(0.163)\end{array}$ & $\begin{array}{c}0.426^{*} \\
(0.170)\end{array}$ & $\begin{array}{l}-0.001 \\
(0.173)\end{array}$ & $\begin{array}{l}0.392^{*} \\
(0.170)\end{array}$ \\
\hline Age squared & $\begin{array}{l}-0.491^{*} \\
(0.209)\end{array}$ & $\begin{array}{c}-0.790^{* * *} \\
(0.203)\end{array}$ & $\begin{array}{c}0.127 \\
(0.150)\end{array}$ & $\begin{array}{c}0.128 \\
(0.173)\end{array}$ & $\begin{array}{l}-0.375^{*} \\
(0.177)\end{array}$ & $\begin{array}{c}0.171 \\
(0.181)\end{array}$ & $\begin{array}{l}-0.455^{*} \\
(0.176)\end{array}$ \\
\hline 1 if female & $\begin{array}{c}-0.119^{* * *} \\
(0.013)\end{array}$ & $\begin{array}{c}0.061^{* * *} \\
(0.013)\end{array}$ & $\begin{array}{c}0.104^{* * *} \\
(0.014)\end{array}$ & $\begin{array}{c}0.055^{* * *} \\
(0.016)\end{array}$ & $\begin{array}{c}0.129^{* * *} \\
(0.017)\end{array}$ & $\begin{array}{l}0.113^{* * *} \\
(0.017)\end{array}$ & $\begin{array}{c}0.110^{* * * *} \\
(0.017)\end{array}$ \\
\hline Subj. math skills & $\begin{array}{l}0.040^{* * *} \\
(0.005)\end{array}$ & $\begin{array}{c}0.032^{* * *} \\
(0.003)\end{array}$ & $\begin{array}{c}0.038^{* * *} \\
(0.003)\end{array}$ & $\begin{array}{c}0.059^{* * *} \\
(0.002)\end{array}$ & $\begin{array}{c}0.069^{* * *} \\
(0.004)\end{array}$ & $\begin{array}{c}0.068^{* * *} \\
(0.003)\end{array}$ & $\begin{array}{c}0.075^{* * *} \\
(0.004)\end{array}$ \\
\hline Income bracket & $\begin{array}{l}0.006^{* *} \\
(0.002)\end{array}$ & $\begin{array}{c}0.012^{* * *} \\
(0.002)\end{array}$ & $\begin{array}{c}0.011^{\text {*** }} \\
(0.002)\end{array}$ & $\begin{array}{l}-0.000 \\
(0.001)\end{array}$ & $\begin{array}{c}0.015^{* * *} \\
(0.002)\end{array}$ & $\begin{array}{c}0.007^{* * *} \\
(0.002)\end{array}$ & $\begin{array}{c}0.015^{* * *} \\
(0.002)\end{array}$ \\
\hline Education level & $\begin{array}{l}-0.005 \\
(0.009)\end{array}$ & $\begin{array}{c}0.081^{* * *} \\
(0.013)\end{array}$ & $\begin{array}{c}0.090^{* * *} \\
(0.012)\end{array}$ & $\begin{array}{l}-0.031^{*} \\
(0.013)\end{array}$ & $\begin{array}{c}0.099^{* * * *} \\
(0.015)\end{array}$ & $\begin{array}{l}0.044^{* * *} \\
(0.014)\end{array}$ & $\begin{array}{c}0.099^{* * *} \\
(0.015)\end{array}$ \\
\hline $\begin{array}{l}\text { WP119 Religion } \\
\text { Important } \\
\text { Constant }\end{array}$ & $\begin{array}{c}-0.068^{* * *} \\
(0.017) \\
0.455^{* * *} \\
(0.078)\end{array}$ & $\begin{array}{c}0.094^{* * *} \\
(0.026) \\
-0.301^{* * *} \\
(0.072)\end{array}$ & $\begin{array}{c}0.175^{* * *} \\
(0.019) \\
-0.522^{* * *} \\
(0.064)\end{array}$ & $\begin{array}{c}0.087^{* * *} \\
(0.024) \\
-0.231^{* *} \\
(0.068)\end{array}$ & $\begin{array}{c}0.212^{* * *} \\
(0.023) \\
-0.628^{* * *} \\
(0.083)\end{array}$ & $\begin{array}{c}0.186^{* * *} \\
(0.023) \\
-0.531^{* * *} \\
(0.067)\end{array}$ & $\begin{array}{c}0.197^{* * *} \\
(0.022) \\
-0.550^{* * *} \\
(0.077)\end{array}$ \\
\hline \multicolumn{8}{|c|}{ Wald test of equality of coefficients } \\
\hline Christianity vs. Islam & $\begin{array}{c}0.008 \\
(0.050)\end{array}$ & $\begin{array}{c}0.028 \\
(0.047)\end{array}$ & $\begin{array}{c}0.057 \\
(0.044)\end{array}$ & $\begin{array}{c}0.079^{+} \\
(0.047)\end{array}$ & $\begin{array}{c}0.088 \\
(0.064)\end{array}$ & $\begin{array}{c}0.094^{+} \\
(0.050)\end{array}$ & $\begin{array}{c}0.087 \\
(0.059)\end{array}$ \\
\hline Christianity vs. & 0.045 & 0.006 & 0.026 & 0.073 & 0.023 & 0.030 & 0.021 \\
\hline & $(0.051)$ & $(0.036)$ & $(0.036)$ & $(0.049)$ & $(0.043)$ & $(0.035)$ & $(0.043)$ \\
\hline
\end{tabular}




\begin{tabular}{|c|c|c|c|c|c|c|c|}
\hline \multirow{2}{*}{$\begin{array}{l}\text { Christianity vs. } \\
\text { Buddhism }\end{array}$} & 0.044 & 0.040 & 0.051 & 0.145 & 0.018 & 0.052 & 0.024 \\
\hline & $(0.043)$ & $(0.056)$ & $(0.049)$ & $(0.139)$ & $(0.053)$ & $(0.067)$ & $(0.055)$ \\
\hline \multirow{2}{*}{$\begin{array}{l}\text { Christianity vs. } \\
\text { Judaism }\end{array}$} & $0.277^{* * *}$ & 0.016 & $0.191^{* * *}$ & 0.067 & $0.162^{* *}$ & $0.179^{* * *}$ & $0.194^{* *}$ \\
\hline & $(0.063)$ & $(0.050)$ & $(0.039)$ & $(0.040)$ & $(0.054)$ & $(0.045)$ & $(0.057)$ \\
\hline Islam vs. Hinduism & $\begin{array}{c}0.053 \\
(0.045)\end{array}$ & $\begin{array}{c}0.022 \\
(0.027)\end{array}$ & $\begin{array}{l}0.083^{*} \\
(0.039)\end{array}$ & $\begin{array}{c}0.006 \\
(0.043)\end{array}$ & $\begin{array}{c}0.066^{*} \\
(0.031)\end{array}$ & $\begin{array}{c}0.064^{*} \\
(0.026)\end{array}$ & $\begin{array}{l}0.066^{*} \\
(0.031)\end{array}$ \\
\hline Islam vs. Buddhism & $\begin{array}{c}0.036 \\
(0.048)\end{array}$ & $\begin{array}{c}0.012 \\
(0.061)\end{array}$ & $\begin{array}{c}0.007 \\
(0.053)\end{array}$ & $\begin{array}{c}0.224 \\
(0.143)\end{array}$ & $\begin{array}{c}0.070 \\
(0.058)\end{array}$ & $\begin{array}{c}0.146^{*} \\
(0.070)\end{array}$ & $\begin{array}{c}0.063 \\
(0.057)\end{array}$ \\
\hline Islam vs. Judaism & $\begin{array}{c}0.269^{* * *} \\
(0.060)\end{array}$ & $\begin{array}{c}0.011 \\
(0.045)\end{array}$ & $\begin{array}{l}0.134^{* *} \\
(0.041)\end{array}$ & $\begin{array}{c}0.012 \\
(0.037)\end{array}$ & $\begin{array}{c}0.073 \\
(0.054)\end{array}$ & $\begin{array}{l}0.085^{+} \\
(0.046)\end{array}$ & $\begin{array}{l}0.107^{+} \\
(0.058)\end{array}$ \\
\hline \multirow[t]{2}{*}{$\begin{array}{l}\text { Hinduism vs. } \\
\text { Buddhism }\end{array}$} & $0.089^{+}$ & 0.034 & 0.076 & 0.218 & 0.005 & 0.082 & 0.003 \\
\hline & $(0.045)$ & $(0.047)$ & $(0.062)$ & $(0.159)$ & $(0.041)$ & $(0.068)$ & $(0.043)$ \\
\hline Hinduism vs. Judaism & $\begin{array}{l}0.322^{* * *} \\
(0.070)\end{array}$ & $\begin{array}{c}0.010 \\
(0.045)\end{array}$ & $\begin{array}{c}0.217^{* * * *} \\
(0.045)\end{array}$ & $\begin{array}{c}0.006 \\
(0.045)\end{array}$ & $\begin{array}{l}0.139^{* *} \\
(0.046)\end{array}$ & $\begin{array}{l}0.149^{* * *} \\
(0.041)\end{array}$ & $\begin{array}{l}0.173^{* *} \\
(0.052)\end{array}$ \\
\hline $\begin{array}{l}\text { Buddhism vs. } \\
\text { Judaism }\end{array}$ & $\begin{array}{l}0.233^{* *} \\
(0.066)\end{array}$ & 0.024 & $\begin{array}{l}0.140^{*} \\
(0.053)\end{array}$ & 0.212 & $\begin{array}{l}0.143^{*} \\
(0.064)\end{array}$ & $\begin{array}{l}0.231^{* *} \\
(0.078)\end{array}$ & $0.170^{*}$ \\
\hline Country FE & Yes & Yes & Yes & Yes & Yes & Yes & Yes \\
\hline Pseudo-R2 & 0.11 & 0.13 & 0.13 & 0.10 & 0.17 & 0.13 & 0.16 \\
\hline Observations & 56031 & 56963 & 56785 & 56230 & 56023 & 56047 & 55298 \\
\hline
\end{tabular}

Tab. S6. Differences in prosocial preferences across world religions. Controlling for religiosity.

Coefficients are based on OLS regressions (for further notes see Tab. S5). Columns (1) to (7) show estimates of a model that accounts for religiosity by adding a binary control variable that takes the value of 0 if religion is not important in a respondent's daily life, and 1 if religion is important in daily life. Columns (1) to (4) show estimates for negative reciprocity (1), positive reciprocity (2), altruism (3) and trust (4). Column (5) to (7) show estimates for the prosocial preference index and alternative versions of the social preferences index (see Tab. S5). Specifications include the following additional control variables: gender, age, age squared, subjective math skills, education level, household income brackets, and country fixed effects. The Wald tests reported at the middle of the table are run on the null hypothesis that coefficients of the categorical variable identifying a religion are equal to each other (differences between coefficients are reported as absolute differences). Standard errors clustered at the country level. $+=$ Statistical significance at the $10 \%$ level; $*=$ Statistical significance at the $5 \%$ level; $* *=$ Statistical significance at the $1 \%$ level; $* * *=$ Statistical significance at the $0.1 \%$ level. 


\begin{tabular}{|c|c|c|c|c|c|c|c|}
\hline & $\begin{array}{c}\text { (1) } \\
\text { Negative } \\
\text { reciprocity }\end{array}$ & $\begin{array}{c}(2) \\
\text { Positive } \\
\text { reciprocity }\end{array}$ & $\begin{array}{c}\text { (3) } \\
\text { Altruism }\end{array}$ & $\begin{array}{c}\text { (4) } \\
\text { Trust }\end{array}$ & $\begin{array}{c}(5) \\
\text { Prosocial } \\
\text { Index }\end{array}$ & $\begin{array}{c}(6) \\
\text { Prosocial } \\
\text { Index I }\end{array}$ & $\begin{array}{c}(7) \\
\text { Prosocial } \\
\text { Index II }\end{array}$ \\
\hline Christianity & $\begin{array}{c}-0.097^{* * *} \\
(0.023)\end{array}$ & $\begin{array}{c}0.004 \\
(0.021)\end{array}$ & $\begin{array}{c}0.133^{* * *} \\
(0.021)\end{array}$ & $\begin{array}{c}0.119^{* * *} \\
(0.017)\end{array}$ & $\begin{array}{c}0.139^{* * *} \\
(0.026)\end{array}$ & $\begin{array}{c}0.178^{* * *} \\
(0.023)\end{array}$ & $\begin{array}{c}0.127^{* * *} \\
(0.025)\end{array}$ \\
\hline Islam & $\begin{array}{l}-0.106^{*} \\
(0.048)\end{array}$ & $\begin{array}{c}0.031 \\
(0.045)\end{array}$ & $\begin{array}{c}0.207^{* * *} \\
(0.043)\end{array}$ & $\begin{array}{c}0.201^{* * *} \\
(0.045)\end{array}$ & $\begin{array}{c}0.238^{* * *} \\
(0.059)\end{array}$ & $\begin{array}{l}0.286^{* * *} \\
(0.047)\end{array}$ & $\begin{array}{c}0.221^{* * *} \\
(0.055)\end{array}$ \\
\hline Hinduism & $\begin{array}{c}-0.158^{* *} \\
(0.052)\end{array}$ & $\begin{array}{c}0.028 \\
(0.042)\end{array}$ & $\begin{array}{l}0.141^{* *} \\
(0.043)\end{array}$ & $\begin{array}{l}0.195^{* *} \\
(0.059)\end{array}$ & $\begin{array}{c}0.194^{* * *} \\
(0.055)\end{array}$ & $\begin{array}{c}0.234^{* * *} \\
(0.048)\end{array}$ & $\begin{array}{l}0.176^{* *} \\
(0.056)\end{array}$ \\
\hline Buddhism & $\begin{array}{l}-0.041 \\
(0.036)\end{array}$ & $\begin{array}{c}0.025 \\
(0.045)\end{array}$ & $\begin{array}{c}0.228^{* * *} \\
(0.044)\end{array}$ & $\begin{array}{c}0.047 \\
(0.091)\end{array}$ & $\begin{array}{c}0.194^{* * *} \\
(0.043)\end{array}$ & $\begin{array}{c}0.202^{* * *} \\
(0.058)\end{array}$ & $\begin{array}{l}0.188^{* * *} \\
(0.041)\end{array}$ \\
\hline Judaism & $\begin{array}{c}0.179^{*} \\
(0.070)\end{array}$ & $\begin{array}{c}0.007 \\
(0.046)\end{array}$ & $\begin{array}{c}0.291^{* * *} \\
(0.042)\end{array}$ & $\begin{array}{c}0.143^{* * *} \\
(0.039)\end{array}$ & $\begin{array}{c}0.253^{* * *} \\
(0.052)\end{array}$ & $\begin{array}{l}0.304^{* * *} \\
(0.042)\end{array}$ & $\begin{array}{c}0.274^{* * *} \\
(0.054)\end{array}$ \\
\hline Other religion & $\begin{array}{l}-0.039 \\
(0.052)\end{array}$ & $\begin{array}{c}0.018 \\
(0.058)\end{array}$ & $\begin{array}{l}0.158^{* *} \\
(0.048)\end{array}$ & $\begin{array}{c}0.057 \\
(0.070)\end{array}$ & $\begin{array}{c}0.138^{*} \\
(0.057)\end{array}$ & $\begin{array}{c}0.152^{*} \\
(0.060)\end{array}$ & $\begin{array}{c}0.124^{*} \\
(0.059)\end{array}$ \\
\hline Age & $\begin{array}{l}-0.396^{+} \\
(0.204)\end{array}$ & $\begin{array}{c}0.783^{* * *} \\
(0.173)\end{array}$ & $\begin{array}{l}-0.210 \\
(0.151)\end{array}$ & $\begin{array}{c}0.283 \\
(0.202)\end{array}$ & $\begin{array}{c}0.496^{*} \\
(0.193)\end{array}$ & $\begin{array}{c}0.064 \\
(0.213)\end{array}$ & $\begin{array}{c}0.445^{*} \\
(0.188)\end{array}$ \\
\hline Age squared & $\begin{array}{l}-0.402^{+} \\
(0.202)\end{array}$ & $\begin{array}{c}-0.814^{* * *} \\
(0.183)\end{array}$ & $\begin{array}{c}0.271^{+} \\
(0.161)\end{array}$ & $\begin{array}{c}0.063 \\
(0.198)\end{array}$ & $\begin{array}{l}-0.329^{+} \\
(0.190)\end{array}$ & $\begin{array}{c}0.228 \\
(0.213)\end{array}$ & $\begin{array}{c}-0.393^{*} \\
(0.187)\end{array}$ \\
\hline 1 if female & $\begin{array}{c}-0.126^{* * *} \\
(0.012)\end{array}$ & $\begin{array}{l}0.053^{* * *} \\
(0.012)\end{array}$ & $\begin{array}{l}0.104^{* * *} \\
(0.014)\end{array}$ & $\begin{array}{l}0.054^{* *} \\
(0.016)\end{array}$ & $\begin{array}{c}0.123^{* * * *} \\
(0.018)\end{array}$ & $\begin{array}{l}0.111^{* * * *} \\
(0.018)\end{array}$ & $\begin{array}{l}0.103^{* * *} \\
(0.017)\end{array}$ \\
\hline Subj. math skills & $\begin{array}{c}0.039^{* * *} \\
(0.004)\end{array}$ & $\begin{array}{c}0.031^{* * *} \\
(0.003)\end{array}$ & $\begin{array}{c}0.036^{* * *} \\
(0.003)\end{array}$ & $\begin{array}{c}0.058^{* * *} \\
(0.003)\end{array}$ & $\begin{array}{c}0.068^{* * *} \\
(0.004)\end{array}$ & $\begin{array}{c}0.067^{* * *} \\
(0.004)\end{array}$ & $\begin{array}{c}0.073^{* * *} \\
(0.004)\end{array}$ \\
\hline Income bracket & $\begin{array}{l}0.006^{* * *} \\
(0.002)\end{array}$ & $\begin{array}{c}0.013^{* * *} \\
(0.002)\end{array}$ & $\begin{array}{c}0.011^{* * *} \\
(0.001)\end{array}$ & $\begin{array}{c}-0.001 \\
(0.001)\end{array}$ & $\begin{array}{c}0.014^{* * * *} \\
(0.002)\end{array}$ & $\begin{array}{c}0.007^{* * * *} \\
(0.001)\end{array}$ & $\begin{array}{c}0.015^{* * *} \\
(0.002)\end{array}$ \\
\hline Education level & $\begin{array}{c}0.003 \\
(0.010)\end{array}$ & $\begin{array}{l}0.076^{* * *} \\
(0.011)\end{array}$ & $\begin{array}{c}0.082^{* * *} \\
(0.012)\end{array}$ & $\begin{array}{c}-0.037^{* *} \\
(0.012)\end{array}$ & $\begin{array}{c}0.087^{* * * *} \\
(0.015)\end{array}$ & $\begin{array}{c}0.033^{*} \\
(0.014)\end{array}$ & $\begin{array}{l}0.088^{* * * *} \\
(0.015)\end{array}$ \\
\hline Constant & $\begin{array}{l}0.426^{* * *} \\
(0.070)\end{array}$ & $\begin{array}{c}-0.281^{* * *} \\
(0.062)\end{array}$ & $\begin{array}{c}-0.424^{* * *} \\
(0.053)\end{array}$ & $\begin{array}{c}-0.198^{* *} \\
(0.059)\end{array}$ & $\begin{array}{c}-0.537^{* * *} \\
(0.070)\end{array}$ & $\begin{array}{c}-0.439^{* * *} \\
(0.057)\end{array}$ & $\begin{array}{c}-0.467^{* * *} \\
(0.065)\end{array}$ \\
\hline \multicolumn{8}{|c|}{ Wald test of equality of coefficients } \\
\hline Christianity vs. Islam & $\begin{array}{c}0.008 \\
(0.046)\end{array}$ & $\begin{array}{c}0.027 \\
(0.043)\end{array}$ & $\begin{array}{c}0.074^{+} \\
(0.039)\end{array}$ & $\begin{array}{c}0.082^{+} \\
(0.042)\end{array}$ & $\begin{array}{c}0.098^{+} \\
(0.057)\end{array}$ & $\begin{array}{c}0.107^{*} \\
(0.045)\end{array}$ & $\begin{array}{c}0.094^{+} \\
(0.053)\end{array}$ \\
\hline Christianity vs. Hinduism & $\begin{array}{c}0.061 \\
(0.049)\end{array}$ & $\begin{array}{c}0.024 \\
(0.038)\end{array}$ & $\begin{array}{c}0.007 \\
(0.040)\end{array}$ & $\begin{array}{c}0.076 \\
(0.053)\end{array}$ & $\begin{array}{c}0.055 \\
(0.053)\end{array}$ & $\begin{array}{c}0.055 \\
(0.045)\end{array}$ & $\begin{array}{c}0.049 \\
(0.053)\end{array}$ \\
\hline Christianity vs. Buddhism & $\begin{array}{c}0.057 \\
(0.041)\end{array}$ & $\begin{array}{c}0.021 \\
(0.044)\end{array}$ & $\begin{array}{c}0.095^{*} \\
(0.045)\end{array}$ & $\begin{array}{c}0.071 \\
(0.097)\end{array}$ & $\begin{array}{c}0.055 \\
(0.041)\end{array}$ & $\begin{array}{c}0.023 \\
(0.060)\end{array}$ & $\begin{array}{c}0.061 \\
(0.038)\end{array}$ \\
\hline
\end{tabular}




\begin{tabular}{|c|c|c|c|c|c|c|c|}
\hline Christianity vs. Judaism & $\begin{array}{l}0.276^{* * *} \\
(0.072)\end{array}$ & $\begin{array}{c}0.003 \\
(0.045)\end{array}$ & $\begin{array}{l}0.158^{* * *} \\
(0.041)\end{array}$ & $\begin{array}{c}0.025 \\
(0.037)\end{array}$ & $\begin{array}{c}0.113^{*} \\
(0.051)\end{array}$ & $\begin{array}{l}0.125^{* *} \\
(0.041)\end{array}$ & $\begin{array}{l}0.147^{* *} \\
(0.051)\end{array}$ \\
\hline \multirow[t]{2}{*}{ Islam vs. Hinduism } & 0.052 & 0.003 & $0.066^{*}$ & 0.006 & 0.043 & 0.052 & 0.045 \\
\hline & $(0.040)$ & $(0.034)$ & $(0.032)$ & $(0.043)$ & $(0.042)$ & $(0.034)$ & $(0.043)$ \\
\hline \multirow[t]{2}{*}{ Islam vs. Buddhism } & 0.065 & 0.006 & 0.021 & 0.154 & 0.043 & 0.084 & 0.033 \\
\hline & $(0.050)$ & $(0.055)$ & $(0.051)$ & $(0.108)$ & $(0.055)$ & $(0.068)$ & $(0.051)$ \\
\hline \multirow[t]{2}{*}{ Islam vs. Judaism } & $0.285^{* * *}$ & 0.024 & $0.084^{*}$ & 0.058 & 0.015 & 0.018 & 0.053 \\
\hline & $(0.071)$ & $(0.041)$ & $(0.041)$ & $(0.036)$ & $(0.051)$ & $(0.044)$ & $(0.052)$ \\
\hline \multirow[t]{2}{*}{ Hinduism vs. Buddhism } & $0.117^{*}$ & 0.003 & 0.088 & 0.148 & 0.000 & 0.032 & 0.012 \\
\hline & $(0.051)$ & $(0.045)$ & $(0.053)$ & $(0.129)$ & $(0.047)$ & $(0.072)$ & $(0.047)$ \\
\hline \multirow{2}{*}{ Hinduism vs. Judaism } & $0.337^{* * *}$ & 0.021 & $0.150^{* *}$ & 0.051 & 0.058 & 0.070 & 0.098 \\
\hline & $(0.079)$ & $(0.047)$ & $(0.047)$ & $(0.051)$ & $(0.056)$ & $(0.048)$ & $(0.059)$ \\
\hline \multirow[t]{2}{*}{ Buddhism vs. Judaism } & $0.220^{* *}$ & 0.018 & 0.063 & 0.096 & 0.058 & 0.102 & 0.086 \\
\hline & $(0.076)$ & $(0.057)$ & $(0.053)$ & $(0.106)$ & $(0.053)$ & $(0.069)$ & $(0.054)$ \\
\hline Country FE & Yes & Yes & Yes & Yes & Yes & Yes & Yes \\
\hline Pseudo-R2 & 0.11 & 0.13 & 0.14 & 0.10 & 0.17 & 0.13 & 0.17 \\
\hline Observations & 68871 & 70038 & 69825 & 69116 & 68867 & 68897 & 67945 \\
\hline
\end{tabular}

Tab. S7. Differences in prosocial preferences across world religions. Excluding countries from the sample.

Coefficients are based on OLS regressions (for further notes see Tab. S5). Columns (1) to (7) show estimates with a reduced sample that exclude the following Muslim countries: Saudi Arabia, Jordan, United Arab Emirates and Egypt (see Extended Methods and Data above). Columns (1) to (4) show estimates for negative reciprocity (1), positive reciprocity (2), altruism (3) and trust (4). Column (5) to (7) show estimates for the prosocial preference index and alternative versions of the social preferences index (see Tab. S5). Specifications include the following control variables: gender, age, age squared, subjective math skills, education level, household income brackets, and country fixed effects. The Wald tests reported at the middle of the table are run on the null hypothesis that coefficients of the categorical variable identifying a religion are equal to each other (differences between coefficients are reported as absolute differences). Standard errors clustered at the country level. $+=$ Statistical significance at the $10 \%$ level; * = Statistical significance at the $5 \%$ level; $* *=$ Statistical significance at the $1 \%$ level; $* * *$ $=$ Statistical significance at the $0.1 \%$ level. 


\begin{tabular}{|c|c|c|c|}
\hline & $\begin{array}{l}(1) \\
2 \mathrm{PP}\end{array}$ & $\begin{array}{c}(2) \\
3 \mathrm{PP}\end{array}$ & $\begin{array}{c}\text { (3) } \\
\text { NR w/o pun }\end{array}$ \\
\hline Christianity & $\begin{array}{c}-0.095^{* * *} \\
(0.023)\end{array}$ & $\begin{array}{c}-0.084^{* * *} \\
(0.024)\end{array}$ & $\begin{array}{c}-0.095^{* * *} \\
(0.021)\end{array}$ \\
\hline Islam & $\begin{array}{l}-0.100^{*} \\
(0.041)\end{array}$ & $\begin{array}{l}-0.117^{* *} \\
(0.037)\end{array}$ & $\begin{array}{l}-0.090^{+} \\
(0.052)\end{array}$ \\
\hline Hinduism & $\begin{array}{c}-0.161^{* * *} \\
(0.048)\end{array}$ & $\begin{array}{c}-0.178^{* * *} \\
(0.045)\end{array}$ & $\begin{array}{l}-0.133^{*} \\
(0.052)\end{array}$ \\
\hline Buddhism & $\begin{array}{c}0.018 \\
(0.046)\end{array}$ & $\begin{array}{c}0.017 \\
(0.059)\end{array}$ & $\begin{array}{l}-0.061 \\
(0.043)\end{array}$ \\
\hline Judaism & $\begin{array}{c}0.080 \\
(0.056)\end{array}$ & $\begin{array}{c}0.231^{* * *} \\
(0.048)\end{array}$ & $\begin{array}{l}0.126^{+} \\
(0.074)\end{array}$ \\
\hline Other religion & $\begin{array}{l}-0.048 \\
(0.047)\end{array}$ & $\begin{array}{l}-0.046 \\
(0.051)\end{array}$ & $\begin{array}{l}-0.034 \\
(0.054)\end{array}$ \\
\hline Age & $\begin{array}{l}-0.190 \\
(0.194)\end{array}$ & $\begin{array}{l}-0.073 \\
(0.181)\end{array}$ & $\begin{array}{l}-0.505^{*} \\
(0.192)\end{array}$ \\
\hline Age squared & $\begin{array}{c}-0.539^{* *} \\
(0.187)\end{array}$ & $\begin{array}{c}-0.587^{* *} \\
(0.178)\end{array}$ & $\begin{array}{l}-0.270 \\
(0.192)\end{array}$ \\
\hline 1 if female & $\begin{array}{c}-0.106^{* * *} \\
(0.012)\end{array}$ & $\begin{array}{c}-0.088^{* * *} \\
(0.010)\end{array}$ & $\begin{array}{c}-0.126^{* * *} \\
(0.013)\end{array}$ \\
\hline Subj. math skills & $\begin{array}{c}0.031^{* * *} \\
(0.003)\end{array}$ & $\begin{array}{c}0.032^{* * *} \\
(0.004)\end{array}$ & $\begin{array}{c}0.037^{* * *} \\
(0.004)\end{array}$ \\
\hline Income bracket & $\begin{array}{l}0.005^{* *} \\
(0.002)\end{array}$ & $\begin{array}{l}0.006^{* * *} \\
(0.002)\end{array}$ & $\begin{array}{l}0.005^{* *} \\
(0.002)\end{array}$ \\
\hline Education level & $\begin{array}{l}0.020^{+} \\
(0.012)\end{array}$ & $\begin{array}{c}0.041^{* * *} \\
(0.010)\end{array}$ & $\begin{array}{l}-0.018^{+} \\
(0.010)\end{array}$ \\
\hline Constant & $\begin{array}{c}0.416^{* * *} \\
(0.061) \\
\end{array}$ & $\begin{array}{c}0.031 \\
(0.055) \\
\end{array}$ & $\begin{array}{c}0.582^{* * *} \\
(0.070)\end{array}$ \\
\hline \multicolumn{4}{|c|}{ Wald test of equality of coefficients } \\
\hline Christianity vs. Islam & $\begin{array}{c}0.005 \\
(0.036)\end{array}$ & $\begin{array}{c}0.033 \\
(0.034)\end{array}$ & $\begin{array}{c}0.004 \\
(0.050)\end{array}$ \\
\hline Christianity vs. Hinduism & $\begin{array}{c}0.066 \\
(0.042)\end{array}$ & $\begin{array}{l}0.094^{*} \\
(0.041)\end{array}$ & $\begin{array}{c}0.038 \\
(0.051)\end{array}$ \\
\hline Christianity vs. Buddhism & $\begin{array}{l}0.113^{*} \\
(0.052)\end{array}$ & $\begin{array}{c}0.101 \\
(0.061)\end{array}$ & $\begin{array}{c}0.033 \\
(0.051)\end{array}$ \\
\hline Christianity vs. Judaism & $\begin{array}{l}0.175^{* *} \\
(0.057)\end{array}$ & $\begin{array}{l}0.315^{* * *} \\
(0.050)\end{array}$ & $\begin{array}{l}0.221^{* *} \\
(0.076)\end{array}$ \\
\hline Islam vs. Hinduism & $\begin{array}{c}0.062^{+} \\
(0.033)\end{array}$ & $\begin{array}{l}0.061^{+} \\
(0.036)\end{array}$ & $\begin{array}{c}0.043 \\
(0.038)\end{array}$ \\
\hline Islam vs. Buddhism & $\begin{array}{l}0.118^{+} \\
(0.061)\end{array}$ & $\begin{array}{l}0.134^{*} \\
(0.062)\end{array}$ & $\begin{array}{c}0.029 \\
(0.063)\end{array}$ \\
\hline Islam vs. Judaism & $\begin{array}{l}0.180^{* *} \\
(0.054)\end{array}$ & $\begin{array}{c}0.348^{* * *} \\
(0.049)\end{array}$ & $\begin{array}{l}0.216^{* *} \\
(0.074)\end{array}$ \\
\hline Hinduism vs. Buddhism & $\begin{array}{l}0.179^{*} \\
(0.074)\end{array}$ & $\begin{array}{l}0.195^{* * *} \\
(0.067)\end{array}$ & $\begin{array}{c}0.072 \\
(0.063)\end{array}$ \\
\hline Hinduism vs. Judaism & $\begin{array}{c}0.241^{* * *} \\
(0.064)\end{array}$ & $\begin{array}{c}0.409^{* * *} \\
(0.058)\end{array}$ & $\begin{array}{l}0.259^{* *} \\
(0.081)\end{array}$ \\
\hline Buddhism vs. Judaism & $\begin{array}{c}0.062 \\
(0.074)\end{array}$ & $\begin{array}{l}0.214^{* *} \\
(0.072)\end{array}$ & $\begin{array}{l}0.187^{*} \\
(0.086)\end{array}$ \\
\hline Country FE & Yes & Yes & Yes \\
\hline Pseudo-R2 & 0.09 & 0.10 & 0.12 \\
\hline Observations & 72946 & 72946 & 72888 \\
\hline
\end{tabular}


Tab. S8. Punishment patterns across world religions. Main results.

Coefficients are based on OLS regressions. Punishment patterns are obtained by decomposing the measure of negative reciprocity into its three components: secondparty punishment, third-party punishment and negative reciprocity without punishment. Positive values indicate that members of world religions exhibited higher levels of the respective preference, negative values indicate that members of world religions exhibited lower levels of the respective preference. The difference between members of world religions and non-religious people was calculated as the coefficient on a categorical variable that takes on the value 0 if respondent is non-religious (reference group), 1 if respondent is Christian, 2 if respondent is Muslim, 3 if respondent is Hindu, 4 if respondent is Buddhist, 5 if respondent is Jewish and 6 if respondent belongs to a non-world religion (other religion). Column (1) shows estimates for second-party punishment. Column (2) shows estimates for third-party punishment, Column (3) shows estimates for negative reciprocity without punishment. Specifications include the following control variables: gender, age, age squared, subjective math skills, education level, household income brackets, and country fixed effects. The Wald tests reported at the middle of the table are run on the null hypothesis that coefficients of the categorical variable identifying a religion are equal to each other (differences between coefficients are reported as absolute differences). Standard errors clustered at the country level. $+=$ Statistical significance at the $10 \%$ level; * = Statistical significance at the 5\% level; ** = Statistical significance at the $1 \%$ level; $* * *=$ Statistical significance at the $0.1 \%$ level. 


\begin{tabular}{|c|c|c|c|c|c|c|}
\hline & (1) & (2) & (3) & (4) & (5) & (6) \\
\hline & $2 \mathrm{PP}$ & 2PP & $3 \mathrm{PP}$ & $3 P P$ & NR w/o pun. & NR w/o pun. \\
\hline \multirow[t]{2}{*}{ Christianity } & $-0.165^{* * *}$ & $-0.100^{* * *}$ & $-0.147^{* * *}$ & $-0.087^{* * *}$ & $-0.167^{* * *}$ & $-0.097^{* * *}$ \\
\hline & $(0.025)$ & $(0.024)$ & $(0.026)$ & $(0.024)$ & $(0.024)$ & $(0.022)$ \\
\hline \multirow[t]{2}{*}{ Islam } & $-0.144^{* *}$ & $-0.110^{* *}$ & $-0.159^{* * *}$ & $-0.129^{* *}$ & $-0.132^{*}$ & $-0.095^{+}$ \\
\hline & $(0.043)$ & $(0.041)$ & $(0.039)$ & $(0.038)$ & $(0.054)$ & $(0.051)$ \\
\hline \multirow[t]{2}{*}{ Hinduism } & $-0.205^{* * *}$ & $-0.161^{* *}$ & $-0.211^{* * *}$ & $-0.170^{* *}$ & $-0.177^{* *}$ & $-0.130^{*}$ \\
\hline & $(0.056)$ & $(0.057)$ & $(0.057)$ & $(0.056)$ & $(0.061)$ & $(0.056)$ \\
\hline \multirow[t]{2}{*}{ Buddhism } & -0.042 & 0.023 & -0.038 & 0.024 & $-0.122^{* *}$ & -0.050 \\
\hline & $(0.049)$ & $(0.049)$ & $(0.061)$ & $(0.060)$ & $(0.044)$ & $(0.042)$ \\
\hline \multirow[t]{2}{*}{ Judaism } & 0.021 & 0.086 & $0.180^{* * *}$ & $0.240^{* * *}$ & 0.060 & $0.129^{+}$ \\
\hline & $(0.051)$ & $(0.057)$ & $(0.043)$ & $(0.048)$ & $(0.070)$ & $(0.077)$ \\
\hline \multirow[t]{2}{*}{ Other religion } & $-0.118^{*}$ & -0.069 & $-0.111^{*}$ & -0.067 & $-0.108^{+}$ & -0.055 \\
\hline & $(0.050)$ & $(0.049)$ & $(0.055)$ & $(0.054)$ & $(0.057)$ & $(0.056)$ \\
\hline \multirow[t]{2}{*}{ Age } & & -0.155 & & -0.014 & & $-0.527^{* *}$ \\
\hline & & $(0.186)$ & & $(0.170)$ & & $(0.189)$ \\
\hline \multirow[t]{2}{*}{ Age squared } & & $-0.680^{* * *}$ & & $-0.777^{* * *}$ & & $-0.326^{+}$ \\
\hline & & $(0.178)$ & & $(0.169)$ & & $(0.190)$ \\
\hline \multirow[t]{2}{*}{1 if female } & & $-0.131^{* * *}$ & & $-0.115^{* * *}$ & & $-0.152^{* * *}$ \\
\hline & & $(0.012)$ & & $(0.009)$ & & $(0.013)$ \\
\hline \multirow{2}{*}{ Constant } & $0.515^{* * *}$ & $0.662^{* * *}$ & $0.203^{* * *}$ & $0.314^{* * * *}$ & $0.571^{* * *}$ & $0.801^{* * *}$ \\
\hline & $(0.043)$ & $(0.057)$ & $(0.039)$ & $(0.053)$ & $(0.054)$ & $(0.062)$ \\
\hline \multicolumn{7}{|c|}{ Wald test of equality of coefficients } \\
\hline \multirow{2}{*}{$\begin{array}{l}\text { Christianity vs. } \\
\text { Islam }\end{array}$} & 0.021 & 0.010 & 0.013 & 0.043 & 0.035 & 0.003 \\
\hline & $(0.036)$ & $(0.036)$ & $(0.033)$ & $(0.035)$ & $(0.050)$ & $(0.049)$ \\
\hline Christianity vs. & 0.040 & 0.061 & 0.064 & 0.083 & 0.010 & 0.033 \\
\hline \multicolumn{7}{|l|}{ Hinduism } \\
\hline $\mathrm{s}$ & $(0.050)$ & $(0.051)$ & $(0.053)$ & $(0.053)$ & $(0.058)$ & $(0.055)$ \\
\hline \multirow{2}{*}{$\begin{array}{l}\text { Christianity vs. } \\
\text { Buddhism }\end{array}$} & $0.123^{*}$ & $0.123^{*}$ & $0.108^{+}$ & $0.111^{+}$ & 0.045 & 0.047 \\
\hline & $(0.053)$ & $(0.054)$ & $(0.062)$ & $(0.061)$ & $(0.051)$ & $(0.050)$ \\
\hline \multirow{2}{*}{$\begin{array}{l}\text { Christianity vs. } \\
\text { Judaism }\end{array}$} & $0.186^{* * *}$ & $0.186^{* *}$ & $0.326^{* * *}$ & $0.326^{* * *}$ & $0.227^{* *}$ & $0.226^{* *}$ \\
\hline & $(0.050)$ & $(0.058)$ & $(0.044)$ & $(0.050)$ & $(0.070)$ & $(0.079)$ \\
\hline \multirow[t]{2}{*}{ Islam vs. Hinduism } & 0.061 & 0.051 & 0.051 & 0.041 & 0.045 & 0.036 \\
\hline & $(0.042)$ & $(0.042)$ & $(0.048)$ & $(0.047)$ & $(0.048)$ & $(0.045)$ \\
\hline \multirow[t]{2}{*}{ Islam vs. Buddhism } & 0.102 & $0.133^{*}$ & $0.121^{+}$ & $0.154^{*}$ & 0.010 & 0.045 \\
\hline & $(0.063)$ & $(0.064)$ & $(0.063)$ & $(0.063)$ & $(0.063)$ & $(0.060)$ \\
\hline \multirow[t]{2}{*}{ Islam vs. Judaism } & $0.165^{* *}$ & $0.196^{* *}$ & $0.339^{* * *}$ & $0.369^{* * *}$ & $0.192^{* *}$ & $0.223^{* *}$ \\
\hline & $(0.048)$ & $(0.055)$ & $(0.042)$ & $(0.049)$ & $(0.069)$ & $(0.078)$ \\
\hline \multirow{2}{*}{$\begin{array}{l}\text { Hinduism vs. } \\
\text { Buddhism }\end{array}$} & $0.163^{+}$ & $0.184^{*}$ & $0.172^{*}$ & $0.194^{*}$ & 0.055 & 0.080 \\
\hline & $(0.082)$ & $(0.087)$ & $(0.077)$ & $(0.078)$ & $(0.066)$ & $(0.060)$ \\
\hline \multirow{2}{*}{$\begin{array}{l}\text { Hinduism vs. } \\
\text { Judaism }\end{array}$} & $0.225^{* *}$ & $0.247^{* *}$ & $0.390^{* * *}$ & $0.410^{* * *}$ & $0.237^{* *}$ & $0.259^{* *}$ \\
\hline & $(0.063)$ & $(0.070)$ & $(0.061)$ & $(0.066)$ & $(0.082)$ & $(0.087)$ \\
\hline \multirow{2}{*}{$\begin{array}{l}\text { Buddhism vs. } \\
\text { Judaism }\end{array}$} & 0.063 & 0.063 & $0.218^{* *}$ & $0.215^{* *}$ & $0.181^{*}$ & $0.179^{*}$ \\
\hline & $(0.070)$ & $(0.076)$ & $(0.069)$ & $(0.073)$ & $(0.081)$ & $(0.087)$ \\
\hline Country FE & Yes & Yes & Yes & Yes & Yes & Yes \\
\hline Pseudo-R2 & 0.06 & 0.08 & 0.07 & 0.09 & 0.08 & 0.11 \\
\hline
\end{tabular}




\section{Tab. S9. Punishment patterns across world religions. Alternative specifications.}

Coefficients are based on OLS regressions (for further notes see Tab. S8). Unconditional models were calculated without controls except of country fixed effects. Models with exogenous individual controls include gender, age, age squared and country fixed effects. Columns (1) and (2) show estimates of second party punishment. Columns (3) and (4) show estimates of third-party punishment, Columns (5) and (6) show estimates of negative reciprocity without punishment. The Wald tests reported at the middle of the table are run on the null hypothesis that coefficients of the categorical variable identifying a religion are equal to each other (differences between coefficients are reported as absolute differences). Standard errors clustered at the country level. $+=$ Statistical significance at the $10 \%$ level; $*=$ Statistical significance at the $5 \%$ level; $* *=$ Statistical significance at the $1 \%$ level; $* * *=$ Statistical significance at the $0.1 \%$ level. 


\begin{tabular}{|c|c|c|c|c|c|c|}
\hline & (1) & (2) & (3) & (4) & (5) & (6) \\
\hline & 2PP & $2 \mathrm{PP}$ & $3 P P$ & $3 P P$ & NR w/o pun. & NR w/o pun. \\
\hline \multirow[t]{2}{*}{ Christianity } & $-0.094^{* * *}$ & $-0.084^{*}$ & $-0.083^{* * *}$ & $-0.104^{* * *}$ & $-0.094^{* * *}$ & $-0.074^{*}$ \\
\hline & $(0.023)$ & $(0.033)$ & $(0.024)$ & $(0.029)$ & $(0.021)$ & $(0.029)$ \\
\hline \multirow[t]{2}{*}{ Islam } & $-0.099^{*}$ & -0.076 & $-0.115^{* *}$ & $-0.124^{* *}$ & $-0.089^{+}$ & -0.053 \\
\hline & $(0.041)$ & $(0.050)$ & $(0.037)$ & $(0.043)$ & $(0.052)$ & $(0.060)$ \\
\hline \multirow[t]{2}{*}{ Hinduism } & $-0.161^{* *}$ & $-0.145^{* *}$ & $-0.177^{* * *}$ & $-0.176^{* * *}$ & $-0.133^{*}$ & $-0.103^{+}$ \\
\hline & $(0.048)$ & $(0.048)$ & $(0.045)$ & $(0.044)$ & $(0.053)$ & $(0.057)$ \\
\hline \multirow[t]{2}{*}{ Buddhism } & 0.019 & 0.064 & 0.018 & 0.061 & -0.061 & -0.082 \\
\hline & $(0.046)$ & $(0.079)$ & $(0.058)$ & $(0.051)$ & $(0.043)$ & $(0.050)$ \\
\hline \multirow[t]{2}{*}{ Judaism } & 0.079 & 0.088 & $0.231^{* * *}$ & $0.212^{* * *}$ & $0.126^{+}$ & $0.146^{*}$ \\
\hline & $(0.056)$ & $(0.054)$ & $(0.048)$ & $(0.045)$ & $(0.074)$ & $(0.063)$ \\
\hline \multirow[t]{2}{*}{ Other religion } & -0.047 & -0.025 & -0.045 & -0.051 & -0.034 & 0.012 \\
\hline & $(0.047)$ & $(0.057)$ & $(0.051)$ & $(0.061)$ & $(0.054)$ & $(0.058)$ \\
\hline \multirow[t]{2}{*}{ Age } & -0.145 & -0.039 & -0.106 & 0.035 & $-0.469^{*}$ & $-0.414^{*}$ \\
\hline & $(0.202)$ & $(0.182)$ & $(0.187)$ & $(0.194)$ & $(0.197)$ & $(0.193)$ \\
\hline \multirow[t]{2}{*}{ Age squared } & $-0.578^{* *}$ & $-0.684^{* * *}$ & $-0.558^{* *}$ & $-0.698^{* * *}$ & -0.302 & $-0.360^{+}$ \\
\hline & $(0.194)$ & $(0.183)$ & $(0.183)$ & $(0.194)$ & $(0.197)$ & $(0.200)$ \\
\hline \multirow[t]{2}{*}{1 if female } & $-0.108^{* * *}$ & $-0.108^{* * *}$ & $-0.086^{* * *}$ & $-0.079^{* * *}$ & $-0.131^{* * *}$ & $-0.125^{* * *}$ \\
\hline & $(0.012)$ & $(0.013)$ & $(0.010)$ & $(0.012)$ & $(0.013)$ & $(0.014)$ \\
\hline \multirow[t]{2}{*}{ Subj. math skills } & $0.031^{* * *}$ & $0.033^{* * *}$ & $0.032^{* * *}$ & $0.033^{* * *}$ & $0.037^{* * *}$ & $0.039^{* * *}$ \\
\hline & $(0.004)$ & $(0.004)$ & $(0.004)$ & $(0.004)$ & $(0.004)$ & $(0.005)$ \\
\hline \multirow[t]{2}{*}{ Income bracket } & $0.006^{* * *}$ & $0.006^{* *}$ & $0.006^{* * *}$ & $0.005^{* *}$ & $0.005^{* *}$ & $0.005^{*}$ \\
\hline & $(0.002)$ & $(0.002)$ & $(0.002)$ & $(0.002)$ & $(0.002)$ & $(0.002)$ \\
\hline \multirow[t]{2}{*}{ Education level } & $0.023^{+}$ & 0.010 & $0.046^{* * * *}$ & $0.038^{* *}$ & -0.015 & $-0.024^{*}$ \\
\hline & $(0.012)$ & $(0.010)$ & $(0.011)$ & $(0.011)$ & $(0.010)$ & $(0.009)$ \\
\hline \multicolumn{2}{|l|}{ WP119 Religion } & $-0.056^{* *}$ & & $-0.036^{+}$ & & $-0.075^{* * *}$ \\
\hline Important & & $(0.019)$ & & $(0.020)$ & & $(0.018)$ \\
\hline \multirow[t]{2}{*}{ Constant } & $0.398^{* * *}$ & $0.419^{* * *}$ & 0.026 & 0.054 & $0.568^{* * *}$ & $0.594^{* * *}$ \\
\hline & $(0.062)$ & $(0.068)$ & $(0.056)$ & $(0.061)$ & $(0.072)$ & $(0.081)$ \\
\hline \multicolumn{7}{|c|}{ Wald test of equality of coefficients } \\
\hline \multirow{2}{*}{$\begin{array}{l}\text { Christianity vs. } \\
\text { Islam }\end{array}$} & 0.004 & 0.008 & 0.032 & 0.020 & 0.005 & 0.021 \\
\hline & $(0.036)$ & $(0.039)$ & $(0.034)$ & $(0.037)$ & $(0.050)$ & $(0.054)$ \\
\hline \multirow{2}{*}{$\begin{array}{l}\text { Christianity vs. } \\
\text { Hinduism }\end{array}$} & 0.067 & 0.061 & $0.094^{*}$ & $0.072^{+}$ & 0.039 & 0.029 \\
\hline & $(0.042)$ & $(0.038)$ & $(0.041)$ & $(0.040)$ & $(0.051)$ & $(0.051)$ \\
\hline \multirow{2}{*}{$\begin{array}{l}\text { Christianity vs. } \\
\text { Buddhism }\end{array}$} & $0.113^{*}$ & $0.148^{+}$ & $0.101^{+}$ & $0.165^{* *}$ & 0.033 & 0.008 \\
\hline & $(0.052)$ & $(0.077)$ & $(0.061)$ & $(0.046)$ & $(0.051)$ & $(0.054)$ \\
\hline \multirow{2}{*}{$\begin{array}{l}\text { Christianity vs. } \\
\text { Judaism }\end{array}$} & $0.174^{* *}$ & $0.172^{* *}$ & $0.314^{* * *}$ & $0.316^{* * *}$ & $0.220^{* *}$ & $0.220^{* *}$ \\
\hline & $(0.057)$ & $(0.054)$ & $(0.051)$ & $(0.048)$ & $(0.076)$ & $(0.066)$ \\
\hline \multirow[t]{2}{*}{ Islam vs. Hinduism } & $0.062^{+}$ & $0.068^{*}$ & $0.062^{+}$ & 0.052 & 0.043 & 0.050 \\
\hline & $(0.033)$ & $(0.031)$ & $(0.036)$ & $(0.039)$ & $(0.038)$ & $(0.041)$ \\
\hline \multirow[t]{2}{*}{ Islam vs. Buddhism } & $0.118^{+}$ & $0.140^{+}$ & $0.134^{*}$ & $0.185^{* * *}$ & 0.029 & 0.029 \\
\hline & $(0.060)$ & $(0.081)$ & $(0.062)$ & $(0.049)$ & $(0.063)$ & $(0.059)$ \\
\hline \multirow[t]{2}{*}{ Islam vs. Judaism } & $0.178^{* *}$ & $0.165^{* *}$ & $0.347^{* * *}$ & $0.336^{* * *}$ & $0.216^{* *}$ & $0.199^{* *}$ \\
\hline & $(0.055)$ & $(0.051)$ & $(0.049)$ & $(0.046)$ & $(0.074)$ & $(0.063)$ \\
\hline Hinduism vs. & $0.180^{*}$ & $0.208^{*}$ & $0.195^{* *}$ & $0.237^{* * *}$ & 0.072 & 0.021 \\
\hline & $(0.074)$ & $(0.092)$ & $(0.067)$ & $(0.054)$ & $(0.063)$ & $(0.054)$ \\
\hline & & & 58 & & & \\
\hline
\end{tabular}




\begin{tabular}{|c|c|c|c|c|c|c|}
\hline \multirow{2}{*}{$\begin{array}{l}\text { Hinduism vs. } \\
\text { Judaism }\end{array}$} & $0.240^{* * *}$ & $0.233^{* * *}$ & $0.408^{* * *}$ & $0.388^{* * *}$ & $0.259^{* *}$ & $0.249^{* *}$ \\
\hline & $(0.064)$ & $(0.057)$ & $(0.058)$ & $(0.052)$ & $(0.081)$ & $(0.071)$ \\
\hline \multirow{2}{*}{$\begin{array}{l}\text { Buddhism vs. } \\
\text { Judaism }\end{array}$} & 0.061 & 0.025 & $0.213^{* *}$ & $0.151^{*}$ & $0.187^{*}$ & $0.228^{* *}$ \\
\hline & $(0.074)$ & $(0.090)$ & $(0.072)$ & $(0.058)$ & $(0.086)$ & $(0.075)$ \\
\hline Country FE & Yes & Yes & Yes & Yes & Yes & Yes \\
\hline Pseudo-R2 & 0.09 & 0.09 & 0.10 & 0.09 & 0.11 & 0.11 \\
\hline Observations & 68928 & 56067 & 68928 & 56069 & 68871 & 56031 \\
\hline
\end{tabular}

Tab. S10. Punishment patterns across world religions. Excluding countries from the sample and controlling for religiosity.

Coefficients are based on OLS regressions (for further notes see Tab. S8). The reduced sample excludes the following Muslim countries: Saudi Arabia, Jordan, United Arab Emirates and Egypt (see Extended Materials and Methods above). The second model accounts for religiosity by adding a binary control variable that takes the value of 0 if religion is not important in a respondent's daily life, and 1 if religion is important in daily life. Columns (1) and (2) show estimates of second party punishment. Columns (3) and (4) show estimates of third-party punishment, Columns (5) and (6) show estimates of negative reciprocity without punishment. Specifications include the following control variables: gender, age, age squared, subjective math skills, education level, household income brackets, and country fixed effects. The Wald tests reported at the middle of the table are run on the null hypothesis that coefficients of the categorical variable identifying a religion are equal to each other (differences between coefficients are reported as absolute differences). Standard errors clustered at the country level. $+=$ Statistical significance at the $10 \%$ level; $*=$ Statistical significance at the 5\% level; $* *=$ Statistical significance at the $1 \%$ level; $* * *=$ Statistical significance at the $0.1 \%$ level. 


\begin{tabular}{|c|c|c|c|c|c|c|}
\hline & $\begin{array}{c}(1) \\
\text { Prosocial } \\
\text { Index }\end{array}$ & $\begin{array}{c}(2) \\
\text { Prosocial } \\
\text { Index }\end{array}$ & $\begin{array}{c}(3) \\
\text { Prosocial } \\
\text { Index }\end{array}$ & $\begin{array}{c}(4) \\
\text { Prosocial } \\
\text { Index }\end{array}$ & $\begin{array}{c}(5) \\
\text { Prosocial } \\
\text { Index }\end{array}$ & $\begin{array}{c}(6) \\
\text { Prosocial } \\
\text { Index }\end{array}$ \\
\hline World religion (Big 5) & $\begin{array}{c}0.089^{*} \\
(0.039)\end{array}$ & $\begin{array}{l}0.201^{* * *} \\
(0.028)\end{array}$ & $\begin{array}{c}0.088^{*} \\
(0.040)\end{array}$ & $\begin{array}{c}0.194^{* * *} \\
(0.026)\end{array}$ & $\begin{array}{c}0.094^{*} \\
(0.039)\end{array}$ & $\begin{array}{c}0.197^{* * *} \\
(0.026)\end{array}$ \\
\hline Other religion & $\begin{array}{l}-0.007 \\
(0.080)\end{array}$ & $\begin{array}{c}0.193^{*} \\
(0.077)\end{array}$ & $\begin{array}{c}-0.004 \\
(0.079)\end{array}$ & $\begin{array}{c}0.189^{*} \\
(0.076)\end{array}$ & $\begin{array}{c}0.025 \\
(0.079)\end{array}$ & $\begin{array}{l}0.213^{* *} \\
(0.072)\end{array}$ \\
\hline Age & & & $\begin{array}{l}0.782^{* * *} \\
(0.258)\end{array}$ & $\begin{array}{c}0.496 \\
(0.339)\end{array}$ & $\begin{array}{c}0.580^{*} \\
(0.218)\end{array}$ & $\begin{array}{c}0.435 \\
(0.306)\end{array}$ \\
\hline Age squared & & & $\begin{array}{c}-0.992^{* * * *} \\
(0.236)\end{array}$ & $\begin{array}{c}-0.473 \\
(0.318)\end{array}$ & $\begin{array}{l}-0.476^{*} \\
(0.214)\end{array}$ & $\begin{array}{l}-0.172 \\
(0.303)\end{array}$ \\
\hline 1 if female & & & $\begin{array}{c}0.086^{* * *} \\
(0.023)\end{array}$ & $\begin{array}{c}0.044^{+} \\
(0.022)\end{array}$ & $\begin{array}{c}0.145^{* * *} \\
(0.023)\end{array}$ & $\begin{array}{c}0.099^{* * *} \\
(0.025)\end{array}$ \\
\hline Subj. math skills & & & & & $\begin{array}{c}0.070^{* * *} \\
(0.005)\end{array}$ & $\begin{array}{c}0.069^{* * *} \\
(0.006)\end{array}$ \\
\hline Income bracket & & & & & $\begin{array}{c}0.014^{* * *} \\
(0.003)\end{array}$ & $\begin{array}{c}0.014^{* * *} \\
(0.002)\end{array}$ \\
\hline Education level & & & & & $\begin{array}{c}0.107^{* * *} \\
(0.018)\end{array}$ & $\begin{array}{c}0.052^{*} \\
(0.023)\end{array}$ \\
\hline Constant & $\begin{array}{c}0.356^{* * *} \\
(0.039)\end{array}$ & $\begin{array}{c}-0.600^{* * *} \\
(0.028)\end{array}$ & $\begin{array}{c}0.182^{*} \\
(0.068)\end{array}$ & $\begin{array}{c}-0.722^{* * *} \\
(0.081)\end{array}$ & $\begin{array}{c}-0.446^{* * *} \\
(0.066)\end{array}$ & $\begin{array}{c}-1.390^{* * * *} \\
(0.075)\end{array}$ \\
\hline
\end{tabular}

Wald test of equality of coefficients

\begin{tabular}{lcccccc} 
World religion (Big 5) & \multicolumn{2}{c}{$0.112^{*}$} & \multicolumn{2}{c}{$0.106^{*}$} & \multicolumn{2}{c}{$0.103^{*}$} \\
& \multicolumn{2}{c}{$(0.048)$} & (0.047) & \multicolumn{2}{c}{$(046)$} \\
\hline Population size & Small & Large & Small & Large & Small & Large \\
Country FE & Yes & Yes & Yes & Yes & Yes & Yes \\
Pseudo-R2 & 0.092 & 0.193 & 0.095 & 0.193 & 0.132 & 0.223 \\
Observations & 37990 & 35905 & 37895 & 35823 & 37468 & 35420 \\
\hline
\end{tabular}

\section{Tab. S11. Religion and population size. Main results and alternative specifications.}

Coefficients are based on OLS regressions. The sample was split into respondents living in countries with small population size (below median) and respondents living in countries with large population size (above median). The summary index of prosocial preferences is based on a principal component analysis of positive reciprocity, altruism and trust. Positive values indicate that members of world religions exhibited higher levels of prosocial preferences, negative values indicate that members of world religions exhibited lower levels of prosocial preferences. The difference between members of world religions and non-religious people was calculated as the coefficient on a categorical variable that takes on the value 0 if respondent is non-religious (reference group), 1 if respondent is part of a world religion (i.e., Christianity, Muslim, Hinduism, Buddhism and Judaism) and 2 if respondent belongs to a non-world religion (other religion). Columns (1) and (2) show estimates on an unconditional model (no controls except of country fixed effects). Columns (3) and (4) show estimates of a model with exogenous individual controls (i.e., gender, age, age squared) and country fixed effects. Columns (5) and (6) show estimates of the main specification that includes the following control variables: gender, age, age squared, subjective math skills, education level, household income brackets, and country fixed effects. The Wald tests reported at the middle of the table are run on the null hypothesis that coefficients identifying a world religion are equal to each other across the two population size samples (differences between coefficients are reported as absolute differences). Standard errors clustered at the country level. $+=$ Statistical significance at the $10 \%$ level; $*$ = Statistical significance at the $5 \%$ level; $* *=$ Statistical significance at the $1 \%$ level; $* * *=$ Statistical significance at the $0.1 \%$ level. 


\begin{tabular}{|c|c|c|c|c|c|c|c|c|}
\hline & $\begin{array}{c}\text { (1) } \\
\text { Prosocial } \\
\text { Index I }\end{array}$ & $\begin{array}{c}(2) \\
\text { Prosocial } \\
\text { Index I }\end{array}$ & $\begin{array}{c}(3) \\
\text { Prosocial } \\
\text { Index II }\end{array}$ & $\begin{array}{c}(4) \\
\text { Prosocial } \\
\text { Index II }\end{array}$ & $\begin{array}{c}(5) \\
\text { Prosocial } \\
\text { Index }\end{array}$ & $\begin{array}{c}\text { (6) } \\
\text { Prosocial } \\
\text { Index }\end{array}$ & $\begin{array}{c}(7) \\
\text { Prosocial } \\
\text { Index }\end{array}$ & $\begin{array}{c}(8) \\
\text { Prosocial } \\
\text { Index }\end{array}$ \\
\hline World religion (Big 5) & $\begin{array}{c}0.142^{* * *} \\
(0.035)\end{array}$ & $\begin{array}{c}0.224^{* * *} \\
(0.020)\end{array}$ & $\begin{array}{c}0.079^{*} \\
(0.037)\end{array}$ & $\begin{array}{c}0.188^{* * *} \\
(0.024)\end{array}$ & $\begin{array}{c}0.097^{*} \\
(0.039)\end{array}$ & $\begin{array}{c}0.197^{* * *} \\
(0.026)\end{array}$ & $\begin{array}{c}0.094^{*} \\
(0.039)\end{array}$ & $\begin{array}{c}0.197^{* * *} \\
(0.026)\end{array}$ \\
\hline Other religion & $\begin{array}{c}0.166^{+} \\
(0.098)\end{array}$ & $\begin{array}{c}0.136^{*} \\
(0.064)\end{array}$ & $\begin{array}{c}0.004 \\
(0.081)\end{array}$ & $\begin{array}{l}0.205^{*} \\
(0.076)\end{array}$ & $\begin{array}{c}0.027 \\
(0.079)\end{array}$ & $\begin{array}{l}0.213^{* *} \\
(0.072)\end{array}$ & $\begin{array}{c}0.025 \\
(0.079)\end{array}$ & $\begin{array}{l}0.213^{* *} \\
(0.072)\end{array}$ \\
\hline Age & $\begin{array}{l}-0.002 \\
(0.221)\end{array}$ & $\begin{array}{c}0.138 \\
(0.325)\end{array}$ & $\begin{array}{c}0.529^{*} \\
(0.218)\end{array}$ & $\begin{array}{c}0.383 \\
(0.292)\end{array}$ & $\begin{array}{c}0.477^{*} \\
(0.211)\end{array}$ & $\begin{array}{c}0.445 \\
(0.314)\end{array}$ & $\begin{array}{c}0.580^{*} \\
(0.218)\end{array}$ & $\begin{array}{c}0.435 \\
(0.306)\end{array}$ \\
\hline Age squared & $\begin{array}{c}0.214 \\
(0.232)\end{array}$ & $\begin{array}{c}0.266 \\
(0.319)\end{array}$ & $\begin{array}{l}-0.554^{*} \\
(0.213)\end{array}$ & $\begin{array}{l}-0.220 \\
(0.295)\end{array}$ & $\begin{array}{l}-0.418^{+} \\
(0.214)\end{array}$ & $\begin{array}{l}-0.166 \\
(0.310)\end{array}$ & $\begin{array}{l}-0.476^{*} \\
(0.214)\end{array}$ & $\begin{array}{l}-0.172 \\
(0.303)\end{array}$ \\
\hline 1 if female & $\begin{array}{l}0.121^{* * *} \\
(0.022)\end{array}$ & $\begin{array}{l}0.099^{* * *} \\
(0.026)\end{array}$ & $\begin{array}{l}0.125^{* * *} \\
(0.023)\end{array}$ & $\begin{array}{l}0.081^{* *} \\
(0.023)\end{array}$ & $\begin{array}{l}0.146^{* * *} \\
(0.024)\end{array}$ & $\begin{array}{l}0.100^{* * *} \\
(0.025)\end{array}$ & $\begin{array}{l}0.145^{\text {*** }} \\
(0.023)\end{array}$ & $\begin{array}{l}0.099^{* * *} \\
(0.025)\end{array}$ \\
\hline Subj. math skills & $\begin{array}{l}0.067^{* * *} \\
(0.004)\end{array}$ & $\begin{array}{c}0.069^{* * *} \\
(0.006)\end{array}$ & $\begin{array}{l}0.073^{* * *} \\
(0.005)\end{array}$ & $\begin{array}{l}0.076^{* * *} \\
(0.006)\end{array}$ & $\begin{array}{l}0.066^{* * *} \\
(0.005)\end{array}$ & $\begin{array}{l}0.069^{* * *} \\
(0.006)\end{array}$ & $\begin{array}{l}0.070^{* * *} \\
(0.005)\end{array}$ & $\begin{array}{l}0.069^{* * *} \\
(0.006)\end{array}$ \\
\hline Income bracket & $\begin{array}{l}0.008^{* *} \\
(0.002)\end{array}$ & $\begin{array}{l}0.005^{* *} \\
(0.002)\end{array}$ & $\begin{array}{l}0.014^{* * *} \\
(0.003)\end{array}$ & $\begin{array}{l}0.015^{* * *} \\
(0.002)\end{array}$ & $\begin{array}{l}0.015^{* * *} \\
(0.003)\end{array}$ & $\begin{array}{l}0.014^{* * *} \\
(0.002)\end{array}$ & $\begin{array}{l}0.014^{* * *} \\
(0.003)\end{array}$ & $\begin{array}{l}0.014^{* * *} \\
(0.002)\end{array}$ \\
\hline Education level & $\begin{array}{c}0.059^{* * *} \\
(0.015)\end{array}$ & $\begin{array}{c}-0.002 \\
(0.020)\end{array}$ & $\begin{array}{l}0.107^{* * *} \\
(0.018)\end{array}$ & $\begin{array}{c}0.052^{*} \\
(0.022)\end{array}$ & $\begin{array}{l}0.111^{* * *} \\
(0.019)\end{array}$ & $\begin{array}{l}0.062^{* *} \\
(0.022)\end{array}$ & $\begin{array}{c}0.107^{* * *} \\
(0.018)\end{array}$ & $\begin{array}{c}0.052^{*} \\
(0.023)\end{array}$ \\
\hline Constant & $\begin{array}{c}-0.325^{* * *} \\
(0.058)\end{array}$ & $\begin{array}{c}-0.511^{* * *} \\
(0.062)\end{array}$ & $\begin{array}{c}-0.366^{* * *} \\
(0.063)\end{array}$ & $\begin{array}{c}-0.813^{* * *} \\
(0.094)\end{array}$ & $\begin{array}{c}-0.426^{* * *} \\
(0.066)\end{array}$ & $\begin{array}{c}-0.837^{* * *} \\
(0.093)\end{array}$ & $\begin{array}{c}-0.446^{* * *} \\
(0.066)\end{array}$ & $\begin{array}{c}-0.810^{* * *} \\
(0.094)\end{array}$ \\
\hline \multicolumn{9}{|c|}{ Wald test of equality of coefficients } \\
\hline World religion (Big 5) & \multicolumn{2}{|c|}{$\begin{array}{c}0.082^{*} \\
(0.040)\end{array}$} & \multicolumn{2}{|c|}{$\begin{array}{c}0.108^{*} \\
(0.044)\end{array}$} & \multicolumn{2}{|c|}{$\begin{array}{c}0.100^{*} \\
(0.046)\end{array}$} & \multicolumn{2}{|c|}{$\begin{array}{l}0.103^{*} \\
(0.046)\end{array}$} \\
\hline Population size & Small & Large & Small & Large & Small & Large & Small & Large \\
\hline Country FE & Yes & Yes & Yes & Yes & Yes & Yes & Yes & Yes \\
\hline Pseudo-R2 & 0.117 & 0.169 & 0.133 & 0.222 & 0.128 & 0.212 & 0.132 & 0.223 \\
\hline Observations & 37486 & 35432 & 36911 & 35044 & 34460 & 34407 & 37468 & 35420 \\
\hline
\end{tabular}

Tab. S12. Religion and population size. Alternative measures of the prosocial preference index, excluding countries from the sample and alternative measures of population size.

Coefficients are based on OLS regressions. The sample was split into respondents living in countries with small population size (below median) and respondents living in countries with large population size (above median) (for further notes see Tab. S11). Columns (1) and (2) show estimates with an alternative measure of the social preference index including altruism and trust. Columns (3) and (4) show estimates with an alternative measure of the social preference index including negative reciprocity, positive reciprocity, altruism and trust. Columns (5) and (6) show estimates with a reduced sample that exclude the following Muslim countries: Saudi Arabia, Jordan, United Arab Emirates and Egypt (see Extended Methods and Data above). Columns (7) and (8) show estimates where the sample was split by the median of population size in the year of 2012. Specifications include the following control variables: gender, age, age squared, subjective math skills, education level, household income brackets, and country fixed effects. The Wald tests reported 
at the middle of the table are run on the null hypothesis that coefficients identifying a world religion are equal to each other across the two population size samples (differences between coefficients are reported as absolute differences). Standard errors clustered at the country level. $+=$ Statistical significance at the $10 \%$ level; $*=$ Statistical significance at the $5 \%$ level; $* *=$ Statistical significance at the $1 \%$ level; $* * *=$ Statistical significance at the $0.1 \%$ level. 


\begin{tabular}{|c|c|c|c|c|c|c|}
\hline & $\begin{array}{c}(1) \\
\text { Prosocial } \\
\text { Index }\end{array}$ & $\begin{array}{c}(2) \\
\text { Prosocial } \\
\text { Index }\end{array}$ & $\begin{array}{c}(3) \\
\text { Prosocial } \\
\text { Index }\end{array}$ & $\begin{array}{c}(4) \\
\text { Prosocial } \\
\text { Index }\end{array}$ & $\begin{array}{c}(5) \\
\text { Prosocial } \\
\text { Index }\end{array}$ & $\begin{array}{c}(6) \\
\text { Prosocial } \\
\text { Index }\end{array}$ \\
\hline World religion (Big 5) & $\begin{array}{c}0.231^{* * *} \\
(0.044)\end{array}$ & $\begin{array}{c}0.134^{* * *} \\
(0.030)\end{array}$ & $\begin{array}{c}0.228^{* * *} \\
(0.043)\end{array}$ & $\begin{array}{c}0.127^{* * *} \\
(0.029)\end{array}$ & $\begin{array}{c}0.252^{* * *} \\
(0.046)\end{array}$ & $\begin{array}{c}0.132^{* * *} \\
(0.028)\end{array}$ \\
\hline Other religion & $\begin{array}{c}0.155 \\
(0.111)\end{array}$ & $\begin{array}{c}0.108 \\
(0.066)\end{array}$ & $\begin{array}{c}0.154 \\
(0.111)\end{array}$ & $\begin{array}{c}0.102 \\
(0.065)\end{array}$ & $\begin{array}{c}0.228^{*} \\
(0.104)\end{array}$ & $\begin{array}{c}0.113^{+} \\
(0.063)\end{array}$ \\
\hline Age & & & $\begin{array}{c}0.584^{*} \\
(0.283)\end{array}$ & $\begin{array}{c}0.743^{*} \\
(0.330)\end{array}$ & $\begin{array}{c}0.569^{*} \\
(0.270)\end{array}$ & $\begin{array}{c}0.498^{+} \\
(0.274)\end{array}$ \\
\hline Age squared & & & $\begin{array}{l}-0.707^{*} \\
(0.310)\end{array}$ & $\begin{array}{c}-0.830^{* *} \\
(0.298)\end{array}$ & $\begin{array}{l}-0.430 \\
(0.315)\end{array}$ & $\begin{array}{l}-0.300 \\
(0.257)\end{array}$ \\
\hline 1 if female & & & $\begin{array}{c}0.013 \\
(0.022)\end{array}$ & $\begin{array}{c}0.111^{* * *} \\
(0.021)\end{array}$ & $\begin{array}{c}0.061^{*} \\
(0.024)\end{array}$ & $\begin{array}{c}0.176^{* * *} \\
(0.020)\end{array}$ \\
\hline Subj. math skills & & & & & $\begin{array}{c}0.068^{* * *} \\
(0.006)\end{array}$ & $\begin{array}{c}0.071^{* * *} \\
(0.005)\end{array}$ \\
\hline Income bracket & & & & & $\begin{array}{c}0.014^{* * *} \\
(0.003)\end{array}$ & $\begin{array}{c}0.015^{* * *} \\
(0.002)\end{array}$ \\
\hline Education level & & & & & $\begin{array}{l}0.053^{*} \\
(0.026)\end{array}$ & $\begin{array}{c}0.100^{* * *} \\
(0.017)\end{array}$ \\
\hline Constant & $\begin{array}{c}0.213^{* * *} \\
(0.044)\end{array}$ & $\begin{array}{c}0.340^{* * *} \\
(0.025)\end{array}$ & $\begin{array}{c}0.108 \\
(0.071)\end{array}$ & $\begin{array}{c}0.158^{+} \\
(0.090)\end{array}$ & $\begin{array}{c}-0.478^{* * *} \\
(0.081)\end{array}$ & $\begin{array}{c}-0.932^{* * *} \\
(0.082)\end{array}$ \\
\hline
\end{tabular}

Wald test of equality of coefficients

\begin{tabular}{|c|c|c|c|c|c|c|}
\hline \multirow{2}{*}{$\begin{array}{l}\text { World religion (Big 5) } \\
\text { Institutional quality }\end{array}$} & \multicolumn{2}{|c|}{$\begin{array}{c}0.097^{+} \\
(0.053)\end{array}$} & \multicolumn{2}{|c|}{$\begin{array}{c}0.101^{*} \\
(0.051)\end{array}$} & \multicolumn{2}{|c|}{$\begin{array}{c}0.120^{*} \\
(0.053)\end{array}$} \\
\hline & Low & High & Low & High & Low & High \\
\hline Country FE & Yes & Yes & Yes & Yes & Yes & Yes \\
\hline Pseudo-R2 & 0.153 & 0.129 & 0.153 & 0.132 & 0.183 & 0.170 \\
\hline Observations & 34529 & 39366 & 34471 & 39247 & 34049 & 38839 \\
\hline
\end{tabular}

Tab. S13. Religion and institutional quality. Main results and alternative specifications.

Coefficients are based on OLS regressions. The sample was split into respondents living in countries with low institutional quality (below median) and respondents living in countries with high institutional quality (above median). The summary index of prosocial preferences is based on a principal component analysis of positive reciprocity, altruism and trust. Positive values indicate that members of world religions exhibited higher levels of prosocial preferences, negative values indicate that members of world religions exhibited lower levels of prosocial preferences. The difference between members of world religions and non-religious people was calculated as the coefficient on a categorical variable that takes on the value 0 if respondent is non-religious (reference group), 1 if respondent is part of a world religion (i.e., Christianity, Muslim, Hinduism, Buddhism and Judaism) and 2 if respondent belongs to a non-world religion (other religion). Columns (1) and (2) show estimates on an unconditional model (no controls except of country fixed effects). Columns (3) and (4) show estimates of a model with exogenous individual controls (i.e., gender, age, age squared) and country fixed effects. Columns (5) and (6) show estimates of the main specification that includes the following control variables: gender, age, age squared, subjective math skills, education level, household income brackets, and country fixed effects. The Wald tests reported at the middle of the table are run on the null hypothesis that coefficients identifying a world religion are equal to each other across the two institutional quality samples (differences between coefficients are reported as absolute differences). Standard errors clustered at the country level. $+=$ Statistical significance at the $10 \%$ level; $*=$ Statistical significance at the $5 \%$ level; $* *=$ Statistical significance at the $1 \%$ level; $* * *=$ Statistical significance at the $0.1 \%$ level. 


\begin{tabular}{|c|c|c|c|c|c|c|c|c|c|c|}
\hline & $\begin{array}{c}(1) \\
\text { Prosocial } \\
\text { Index I }\end{array}$ & $\begin{array}{c}(2) \\
\text { Prosocial } \\
\text { Index I }\end{array}$ & $\begin{array}{c}(3) \\
\text { Prosocial } \\
\text { Index II } \\
\end{array}$ & $\begin{array}{c}(4) \\
\text { Prosocial } \\
\text { Index II } \\
\end{array}$ & $\begin{array}{c}(5) \\
\text { Prosocial } \\
\text { Index } \\
\end{array}$ & $\begin{array}{c}(6) \\
\text { Prosocial } \\
\text { Index } \\
\end{array}$ & $\begin{array}{c}(7) \\
\text { Prosocial } \\
\text { Index } \\
\end{array}$ & $\begin{array}{c}(8) \\
\text { Prosocial } \\
\text { Index } \\
\end{array}$ & $\begin{array}{c}(9) \\
\text { Prosocial } \\
\text { Index } \\
\end{array}$ & $\begin{array}{c}(10) \\
\text { Prosocial } \\
\text { Index } \\
\end{array}$ \\
\hline World religion (Big 5) & $\begin{array}{c}0.247^{* * *} \\
(0.042)\end{array}$ & $\begin{array}{l}0.173^{* * *} \\
(0.024)\end{array}$ & $\begin{array}{l}0.221^{* * *} \\
(0.040)\end{array}$ & $\begin{array}{l}0.122^{* * *} \\
(0.027)\end{array}$ & $\begin{array}{l}0.257^{* * *} \\
(0.046)\end{array}$ & $\begin{array}{l}0.132^{* * *} \\
(0.028)\end{array}$ & $\begin{array}{c}0.255^{* * *} \\
(0.048)\end{array}$ & $\begin{array}{c}0.132^{* * *} \\
(0.028)\end{array}$ & $\begin{array}{l}0.254^{* * *} \\
(0.045)\end{array}$ & $\begin{array}{l}0.132^{* * *} \\
(0.028)\end{array}$ \\
\hline Other religion & $\begin{array}{l}0.303^{*} \\
(0.122)\end{array}$ & $\begin{array}{c}0.085 \\
(0.057)\end{array}$ & $\begin{array}{l}0.223^{*} \\
(0.101)\end{array}$ & $\begin{array}{c}0.091 \\
(0.067)\end{array}$ & $\begin{array}{l}0.232^{*} \\
(0.105)\end{array}$ & $\begin{array}{c}0.113^{+} \\
(0.063)\end{array}$ & $\begin{array}{c}0.204^{+} \\
(0.110)\end{array}$ & $\begin{array}{c}0.123^{+} \\
(0.062)\end{array}$ & $\begin{array}{c}0.230^{*} \\
(0.105)\end{array}$ & $\begin{array}{c}0.113^{+} \\
(0.063)\end{array}$ \\
\hline Age & $\begin{array}{c}0.356 \\
(0.304)\end{array}$ & $\begin{array}{c}-0.084 \\
(0.248)\end{array}$ & $\begin{array}{l}0.495^{+} \\
(0.259)\end{array}$ & $\begin{array}{c}0.463 \\
(0.277)\end{array}$ & $\begin{array}{c}0.512^{+} \\
(0.290)\end{array}$ & $\begin{array}{c}0.498^{+} \\
(0.274)\end{array}$ & $\begin{array}{c}0.624^{*} \\
(0.269)\end{array}$ & $\begin{array}{c}0.476^{+} \\
(0.267)\end{array}$ & $\begin{array}{c}0.634^{*} \\
(0.275)\end{array}$ & $\begin{array}{c}0.498^{+} \\
(0.274)\end{array}$ \\
\hline Age squared & $\begin{array}{c}-0.150 \\
(0.312)\end{array}$ & $\begin{array}{c}0.426^{+} \\
(0.248)\end{array}$ & $\begin{array}{l}-0.468 \\
(0.308)\end{array}$ & $\begin{array}{l}-0.380 \\
(0.259)\end{array}$ & $\begin{array}{c}-0.422 \\
(0.333)\end{array}$ & $\begin{array}{l}-0.300 \\
(0.257)\end{array}$ & $\begin{array}{l}-0.500 \\
(0.313)\end{array}$ & $\begin{array}{l}-0.273 \\
(0.251)\end{array}$ & $\begin{array}{c}-0.466 \\
(0.323)\end{array}$ & $\begin{array}{l}-0.300 \\
(0.257)\end{array}$ \\
\hline 1 if female & $\begin{array}{c}0.042^{+} \\
(0.021)\end{array}$ & $\begin{array}{l}0.168^{* * *} \\
(0.020)\end{array}$ & $\begin{array}{l}0.045^{+} \\
(0.023)\end{array}$ & $\begin{array}{l}0.154^{* * *} \\
(0.019)\end{array}$ & $\begin{array}{l}0.053^{*} \\
(0.026)\end{array}$ & $\begin{array}{l}0.176^{* * *} \\
(0.020)\end{array}$ & $\begin{array}{l}0.063^{*} \\
(0.025)\end{array}$ & $\begin{array}{l}0.169^{* * * *} \\
(0.020)\end{array}$ & $\begin{array}{c}0.060^{*} \\
(0.025)\end{array}$ & $\begin{array}{l}0.176^{* * *} \\
(0.020)\end{array}$ \\
\hline Subj. math skills & $\begin{array}{l}0.069^{* * *} \\
(0.006)\end{array}$ & $\begin{array}{l}0.067^{* * *} \\
(0.005)\end{array}$ & $\begin{array}{l}0.074^{* * *} \\
(0.006)\end{array}$ & $\begin{array}{l}0.075^{* * *} \\
(0.005)\end{array}$ & $\begin{array}{l}0.065^{* * *} \\
(0.006)\end{array}$ & $\begin{array}{l}0.071^{* * *} \\
(0.005)\end{array}$ & $\begin{array}{l}0.067^{* * *} \\
(0.006)\end{array}$ & $\begin{array}{l}0.071^{* * *} \\
(0.005)\end{array}$ & $\begin{array}{l}0.068^{* * *} \\
(0.006)\end{array}$ & $\begin{array}{l}0.071^{* * *} \\
(0.005)\end{array}$ \\
\hline Income bracket & $\begin{array}{l}0.006^{*} \\
(0.002)\end{array}$ & $\begin{array}{l}0.007^{* * *} \\
(0.002)\end{array}$ & $\begin{array}{l}0.014^{* * *} \\
(0.002)\end{array}$ & $\begin{array}{l}0.015^{* * *} \\
(0.002)\end{array}$ & $\begin{array}{l}0.014^{* * *} \\
(0.003)\end{array}$ & $\begin{array}{l}0.015^{* * *} \\
(0.002)\end{array}$ & $\begin{array}{l}0.013^{* * *} \\
(0.003)\end{array}$ & $\begin{array}{l}0.015^{* * *} \\
(0.002)\end{array}$ & $\begin{array}{l}0.014^{* * *} \\
(0.003)\end{array}$ & $\begin{array}{l}0.015^{* * *} \\
(0.002)\end{array}$ \\
\hline Education level & $\begin{array}{l}-0.011 \\
(0.020)\end{array}$ & $\begin{array}{l}0.059^{* *} \\
(0.017)\end{array}$ & $\begin{array}{l}0.052^{*} \\
(0.025)\end{array}$ & $\begin{array}{l}0.101^{* * *} \\
(0.017)\end{array}$ & $\begin{array}{l}0.064^{*} \\
(0.026)\end{array}$ & $\begin{array}{l}0.100^{* * *} \\
(0.017)\end{array}$ & $\begin{array}{c}0.057^{*} \\
(0.027)\end{array}$ & $\begin{array}{l}0.096^{* * *} \\
(0.017)\end{array}$ & $\begin{array}{c}0.053^{+} \\
(0.027)\end{array}$ & $\begin{array}{l}0.100^{* * *} \\
(0.017)\end{array}$ \\
\hline Constant & $\begin{array}{c}-0.356^{* * *} \\
(0.068)\end{array}$ & $\begin{array}{c}-0.618^{* * *} \\
(0.063)\end{array}$ & $\begin{array}{c}-0.391^{* * *} \\
(0.076)\end{array}$ & $\begin{array}{c}-0.915^{* * *} \\
(0.081)\end{array}$ & $\begin{array}{c}-0.469^{* * *} \\
(0.084)\end{array}$ & $\begin{array}{c}-0.932^{* * *} \\
(0.082)\end{array}$ & $\begin{array}{c}-0.485^{* * *} \\
(0.083)\end{array}$ & $\begin{array}{c}-0.927^{* * *} \\
(0.082)\end{array}$ & $\begin{array}{c}-0.992^{* * *} \\
(0.095)\end{array}$ & $\begin{array}{c}-0.932^{* * *} \\
(0.082)\end{array}$ \\
\hline
\end{tabular}

Wald test of equality of coefficients

\begin{tabular}{|c|c|c|c|c|c|c|c|c|c|c|}
\hline \multirow{2}{*}{$\begin{array}{l}\text { World religion (Big 5) } \\
\text { Institutional Quality }\end{array}$} & \multicolumn{2}{|c|}{$\begin{array}{c}0.074 \\
(0.048)\end{array}$} & \multicolumn{2}{|c|}{$\begin{array}{c}0.099^{+} \\
(0.048)\end{array}$} & \multicolumn{2}{|c|}{$\begin{array}{c}0.126^{*} \\
(0.053)\end{array}$} & \multicolumn{2}{|c|}{$\begin{array}{c}0.123^{*} \\
(0.055)\end{array}$} & \multicolumn{2}{|c|}{$\begin{array}{c}0.123^{*} \\
(0.053)\end{array}$} \\
\hline & Low & High & Low & High & Low & High & Low & High & Low & High \\
\hline Country FE & Yes & Yes & Yes & Yes & Yes & Yes & Yes & Yes & Yes & Yes \\
\hline Pseudo-R2 & 0.145 & 0.141 & 0.183 & 0.171 & 0.171 & 0.170 & 0.179 & 0.169 & 0.190 & 0.170 \\
\hline Observations & 34054 & 38864 & 33725 & 38230 & 30028 & 38839 & 32114 & 40774 & 32106 & 38839 \\
\hline
\end{tabular}

\section{Tab. S14. Religion and institutional quality. Alternative measures of the prosocial preference index, excluding countries from the sample and} alternative measures of institutional quality.

Coefficients are based on OLS regressions. The sample was split into respondents in countries with low institutional quality (below median) and respondents living in countries with high institutional quality (above median) (for further notes see Tab. S13). Columns (1) and (2) show estimates with an alternative measure of the social preference index including altruism and trust. Columns (3) and (4) show estimates with an alternative measure of the social preference index including negative reciprocity, positive reciprocity, altruism and trust. Columns (5) and (6) show estimates with a reduced sample that exclude the following Muslim countries: Saudi Arabia, Jordan, United Arab Emirates and Egypt (see Extended Methods and Data above). Columns (7) and (8) show estimates where the sample was split by the median of institutional quality in the year of 2012. Columns (9) and (10) show estimates with a sample that excludes Afghanistan and Bosnia Herzegovina (due to missing values for institutional quality). Specifications include the following control variables: 
gender, age, age squared, subjective math skills, education level, household income brackets, and country fixed effects. The Wald tests reported at the middle of the table are run on the null hypothesis that coefficients identifying a world religion are equal to each other across the two institutional quality samples (differences between coefficients are reported as absolute differences). Standard errors clustered at the country level. $+=$ Statistical significance at the $10 \%$ level; $*=$ Statistical significance at the $5 \%$ level; $* *=$ Statistical significance at the $1 \%$ level; $* * *=$ Statistical significance at the $0.1 \%$ level. 


\begin{tabular}{lcccc}
\hline & $(1)$ & $(2)$ & $(3)$ & $(4)$ \\
& SP index & SP index & SP index & SP index \\
\hline World religion (Big 5) & $0.094^{*}$ & $0.197^{* * *}$ & $0.252^{* * *}$ & $0.132^{* * *}$ \\
& $(0.039)$ & $(0.026)$ & $(0.046)$ & $(0.028)$ \\
Other religion & 0.025 & $0.213^{* *}$ & $0.228^{*}$ & $0.113^{+}$ \\
Age & $(0.079)$ & $(0.072)$ & $(0.104)$ & $(0.063)$ \\
Age squared & $0.580^{*}$ & 0.435 & $0.569^{*}$ & $0.498^{+}$ \\
& $(0.218)$ & $(0.306)$ & $(0.270)$ & $(0.274)$ \\
1 if female & $-0.476^{*}$ & -0.172 & -0.430 & -0.300 \\
Subj. math skills & $(0.214)$ & $(0.303)$ & $(0.315)$ & $(0.257)$ \\
Income bracket & $0.145^{* * *}$ & $0.099^{* * *}$ & $0.061^{*}$ & $0.176^{* * *}$ \\
Education level & $(0.023)$ & $(0.025)$ & $(0.024)$ & $(0.020)$ \\
& $0.070^{* * *}$ & $0.069^{* * *}$ & $0.068^{* * *}$ & $0.071^{* * *}$ \\
Kinship intensity index & $(0.005)$ & $(0.006)$ & $(0.006)$ & $(0.005)$ \\
(KII based on EA) & $0.014^{* * *}$ & $0.014^{* * *}$ & $0.014^{* * *}$ & $0.015^{* * *}$ \\
Constant & $(0.003)$ & $(0.002)$ & $(0.003)$ & $(0.002)$ \\
& $0.107^{* * *}$ & $0.052^{*}$ & $0.053^{*}$ & $0.100^{* * *}$ \\
& $(0.018)$ & $(0.023)$ & $(0.026)$ & $(0.017)$ \\
& $0.228^{* * *}$ & $-0.500^{* * *}$ & $0.211^{* * *}$ & $3.762^{* * *}$ \\
& $(0.007)$ & $(0.024)$ & $(0.009)$ & $(0.128)$ \\
& $-0.682^{* * *}$ & $-1.410^{* * *}$ & $-0.696^{* * *}$ & $3.586^{* * *}$ \\
& $(0.071)$ & $(0.075)$ & $(0.087)$ & $(0.196)$ \\
\hline
\end{tabular}

Wald test of equality of coefficients

\begin{tabular}{lcccc} 
World religion (Big 5) & \multicolumn{2}{c}{$0.103^{*}$} & \multicolumn{2}{c}{$0.120^{*}$} \\
& & $(0.046)$ & - & $(0.053)$ \\
\hline Population size & Small & Large & Low & High \\
Institutional quality & - & - & Yes & Yes \\
Country FE & Yes & Yes & 0.183 & 0.170 \\
Pseudo-R2 & 0.132 & 0.223 & 34049 & 38839 \\
Observations & 37468 & 35420 &
\end{tabular}

Tab. S15. Religion, population size and institutional quality. Controlling for kinship intensity. Coefficients are based on OLS regressions. The summary index of prosocial preferences is based on a principal component analysis of positive reciprocity, altruism and trust. Positive values indicate that members of world religions exhibited higher levels of prosocial preferences, negative values indicate that members of world religions exhibited lower levels of prosocial preferences. The kinship intensity index was taken from Schulz et al. (2019). The difference between members of world religions and non-religious people was calculated as the coefficient on a categorical variable that takes on the value 0 if respondent is non-religious (reference group), 1 if respondent is part of a world religion (i.e., Christianity, Muslim, Hinduism, Buddhism and Judaism) and 2 if respondent belongs to a non-world religion (other religion). In columns (1) and (2) the sample was split into respondents living in countries with small population size (below median) and respondents living in countries with large population size (above median). In columns (3) and (4) the sample was split into respondents living in countries with low institutional quality (below median) and respondents living in countries with high institutional quality (above median). The Wald tests reported at the middle of the table are run on the null hypothesis that coefficients identifying a world religion are equal to each other across the two samples (differences between coefficients are reported as absolute differences). Standard errors clustered at the country level. $+=$ Statistical significance at the $10 \%$ level; $*=$ Statistical significance at the $5 \%$ level; $* *=$ Statistical significance at the $1 \%$ level; $* * *$ $=$ Statistical significance at the $0.1 \%$ level. 


\begin{tabular}{|c|c|c|c|c|c|c|c|c|c|c|c|c|}
\hline & $\begin{array}{c}(1) \\
\text { Prosocial } \\
\text { Index }\end{array}$ & $\begin{array}{c}(2) \\
\text { Prosocial } \\
\text { Index } \\
\end{array}$ & $\begin{array}{c}(3) \\
\text { Prosocial } \\
\text { Index }\end{array}$ & $\begin{array}{c}(4) \\
\text { Prosocial } \\
\text { Index }\end{array}$ & $\begin{array}{c}(5) \\
\text { Prosocial } \\
\text { Index }\end{array}$ & $\begin{array}{c}(6) \\
\text { Prosocial } \\
\text { Index }\end{array}$ & $\begin{array}{c}(7) \\
\text { Prosocial } \\
\text { Index }\end{array}$ & $\begin{array}{c}(8) \\
\text { Prosocial } \\
\text { Index }\end{array}$ & $\begin{array}{c}(9) \\
\text { Prosocial } \\
\text { Index } \\
\end{array}$ & $\begin{array}{c}(10) \\
\text { Prosocial } \\
\text { Index }\end{array}$ & $\begin{array}{c}(11) \\
\text { Prosocial } \\
\text { Index }\end{array}$ & $\begin{array}{c}(12) \\
\text { Prosocial } \\
\text { Index }\end{array}$ \\
\hline $\begin{array}{l}\text { World religion } \\
\text { (Big 5) }\end{array}$ & $\begin{array}{c}0.125 \\
(0.094)\end{array}$ & $\begin{array}{c}0.086 \\
(0.042)\end{array}$ & $\begin{array}{l}0.277^{* * *} \\
(0.037)\end{array}$ & $\begin{array}{l}0.187^{* * *} \\
(0.031)\end{array}$ & $\begin{array}{c}0.126 \\
(0.092)\end{array}$ & $\begin{array}{c}0.080 \\
(0.042)\end{array}$ & $\begin{array}{l}0.273^{* * *} \\
(0.035)\end{array}$ & $\begin{array}{l}0.177^{* * *} \\
(0.028)\end{array}$ & $\begin{array}{c}0.142 \\
(0.096)\end{array}$ & $\begin{array}{l}0.086^{*} \\
(0.041)\end{array}$ & $\begin{array}{l}0.302^{* * *} \\
(0.035)\end{array}$ & $\begin{array}{c}0.178^{* * *} \\
(0.026)\end{array}$ \\
\hline Other religion & $\begin{array}{c}0.035 \\
(0.159)\end{array}$ & $\begin{array}{l}-0.014 \\
(0.071)\end{array}$ & $\begin{array}{c}0.221 \\
(0.154)\end{array}$ & $\begin{array}{c}0.190 \\
(0.091)\end{array}$ & $\begin{array}{c}0.039 \\
(0.159)\end{array}$ & $\begin{array}{l}-0.024 \\
(0.068)\end{array}$ & $\begin{array}{c}0.216 \\
(0.156)\end{array}$ & $\begin{array}{c}0.184 \\
(0.088)\end{array}$ & $\begin{array}{c}0.107 \\
(0.146)\end{array}$ & $\begin{array}{l}-0.033 \\
(0.079)\end{array}$ & $\begin{array}{c}0.287 \\
(0.154)\end{array}$ & $\begin{array}{c}0.199^{*} \\
(0.081)\end{array}$ \\
\hline 1 if female & & & & & $\begin{array}{c}0.025 \\
(0.030)\end{array}$ & $\begin{array}{c}0.133^{* * *} \\
(0.030)\end{array}$ & $\begin{array}{c}0.002 \\
(0.032)\end{array}$ & $\begin{array}{l}0.085^{* *} \\
(0.028)\end{array}$ & $\begin{array}{l}0.071^{*} \\
(0.032)\end{array}$ & $\begin{array}{c}0.202^{* * *} \\
(0.027)\end{array}$ & $\begin{array}{c}0.053 \\
(0.035)\end{array}$ & $\begin{array}{l}0.144^{* * *} \\
(0.029)\end{array}$ \\
\hline Age & & & & & $\begin{array}{c}0.565 \\
(0.358)\end{array}$ & $\begin{array}{c}0.956^{*} \\
(0.398)\end{array}$ & $\begin{array}{c}0.588 \\
(0.439)\end{array}$ & $\begin{array}{c}0.467 \\
(0.546)\end{array}$ & $\begin{array}{c}0.583 \\
(0.313)\end{array}$ & $\begin{array}{c}0.590 \\
(0.329)\end{array}$ & $\begin{array}{c}0.509 \\
(0.428)\end{array}$ & $\begin{array}{c}0.343 \\
(0.459)\end{array}$ \\
\hline Age squared & & & & & $\begin{array}{l}-0.774 \\
(0.416)\end{array}$ & $\begin{array}{c}-1.159^{* *} \\
(0.357)\end{array}$ & $\begin{array}{l}-0.623 \\
(0.452)\end{array}$ & $\begin{array}{l}-0.414 \\
(0.488)\end{array}$ & $\begin{array}{l}-0.560 \\
(0.380)\end{array}$ & $\begin{array}{l}-0.437 \\
(0.319)\end{array}$ & $\begin{array}{l}-0.246 \\
(0.478)\end{array}$ & $\begin{array}{l}-0.086 \\
(0.423)\end{array}$ \\
\hline $\begin{array}{l}\text { Subj. math } \\
\text { skills }\end{array}$ & & & & & & & & & $\begin{array}{l}0.068^{* * *} \\
(0.009)\end{array}$ & $\begin{array}{l}0.071^{* * *} \\
(0.005)\end{array}$ & $\begin{array}{l}0.068^{* * *} \\
(0.008)\end{array}$ & $\begin{array}{l}0.070^{* * *} \\
(0.009)\end{array}$ \\
\hline Income bracket & & & & & & & & & $\begin{array}{l}0.010^{*} \\
(0.004)\end{array}$ & $\begin{array}{c}0.017^{* * *} \\
(0.003)\end{array}$ & $\begin{array}{l}0.016^{* * *} \\
(0.004)\end{array}$ & $\begin{array}{l}0.012^{* *} \\
(0.003)\end{array}$ \\
\hline Education level & & & & & & & & & $\begin{array}{c}0.068 \\
(0.035)\end{array}$ & $\begin{array}{c}0.128^{* * *} \\
(0.017)\end{array}$ & $\begin{array}{c}0.042 \\
(0.036)\end{array}$ & $\begin{array}{c}0.062^{*} \\
(0.028)\end{array}$ \\
\hline Constant & $\begin{array}{l}0.319^{* *} \\
(0.094)\end{array}$ & $\begin{array}{l}0.126^{* *} \\
(0.035)\end{array}$ & $\begin{array}{c}-1.104^{* * *} \\
(0.036)\end{array}$ & $\begin{array}{l}0.293^{* * *} \\
(0.027)\end{array}$ & $\begin{array}{c}0.217^{*} \\
(0.102)\end{array}$ & $\begin{array}{l}-0.098 \\
(0.112)\end{array}$ & $\begin{array}{c}-1.218^{* * *} \\
(0.106)\end{array}$ & $\begin{array}{c}0.143 \\
(0.147)\end{array}$ & $\begin{array}{l}-0.352^{* *} \\
(0.108)\end{array}$ & $\begin{array}{c}-1.204^{* * *} \\
(0.099)\end{array}$ & $\begin{array}{c}-1.768^{* * *} \\
(0.116)\end{array}$ & $\begin{array}{c}-0.791^{* * *} \\
(0.114)\end{array}$ \\
\hline Sample split & LIQ-SP & HIQ-SP & LIQ-LP & HIQ-LP & LIQ-SP & HIQ-SP & LIQ-LP & HIQ-LP & LIQ-SP & HIQ-SP & LIQ-LP & HIQ-LP \\
\hline $\begin{array}{l}\text { Institutional } \\
\text { quality }\end{array}$ & Low & High & Low & High & Low & High & Low & High & Low & High & Low & High \\
\hline Population size & Small & Small & Large & Large & Small & Small & Large & Large & Small & Small & Large & Large \\
\hline Country FE & Yes & Yes & Yes & Yes & Yes & Yes & Yes & Yes & Yes & Yes & Yes & Yes \\
\hline Pseudo-R2 & 0.096 & 0.082 & 0.198 & 0.181 & 0.097 & 0.087 & 0.198 & 0.183 & 0.129 & 0.131 & 0.228 & 0.215 \\
\hline Observations & 16525 & 21465 & 18004 & 17901 & 16483 & 21412 & 17988 & 17835 & 16325 & 21143 & 17724 & 17696 \\
\hline
\end{tabular}

Tab. S16. The impact of the interactive effect of institutional quality and population size on religion. Main results and alternative specifications.

Coefficients are based on OLS regressions. The sample was split into four categories (median split of population size and institutional quality): i) LIQ-SP = Low institutional quality and small population size, ii) HIQ-SP = High institutional quality and small population size, iii) LIQ-LP = Low institutional quality and large population size, and iv) HIQ-LP = High institutional quality and large population size (for further notes see Tab. S11 and S13). Columns (1) to (4) show estimates on an unconditional model (no controls except of country fixed effects). Columns (5) to (8) show estimates of a model with exogenous individual controls (i.e., gender, age, age squared) and country fixed effects. Columns (9) and (12) show estimates of the main specification that includes the following control variables: gender, age, age squared, subjective math skills, education level, household income brackets, and country fixed effects. The corresponding Wald tests are reported in Tab. S17. Standard errors clustered at the country level. $+=$ Statistical significance at the $10 \%$ level; $*=$ Statistical significance at the $5 \%$ level; $* *=$ Statistical significance at the $1 \%$ level; $* * *=$ Statistical significance at the $0.1 \%$ level. 


\begin{tabular}{lccc}
\hline & $(1)$ & $(2)$ & $(3)$ \\
& Prosocial Index & Prosocial Index & Prosocial Index \\
\hline LIQ_SP vs. LIQ_LP & 0.152 & 0.148 & 0.160 \\
& $(0.098)$ & $(0.097)$ & $(0.100)$ \\
LIQ_SP vs. HIQ_SP & 0.039 & 0.045 & 0.055 \\
& $(0.100)$ & $(0.099)$ & $(0.102)$ \\
LIQ_SP vs. HIQ_LP & 0.062 & 0.051 & 0.037 \\
& $(0.097)$ & $(0.094)$ & $(0.097)$ \\
LIQ_LP vs. HIQ_SP & $0.190^{* * *}$ & $0.193^{* * *}$ & $0.215^{* * *}$ \\
& $(0.055)$ & $(0.054)$ & $(0.053)$ \\
LIQ_LP vs. HIQ_LP & $0.089^{+}$ & $0.096^{* *}$ & $0.123^{* *}$ \\
& $(0.047)$ & $(0.044)$ & $(0.043)$ \\
HIQ_SP vs. HIQ_LP & $0.101^{*}$ & $0.097^{+}$ & $0.092^{+}$ \\
& $(0.051)$ & $(0.050)$ & $(0.048)$ \\
\hline Model & Unconditional model & Model with & Main specification \\
& (Columns 1 to 4 in & exogenous individual & (Columns 9 to 10 in \\
& Tab. S16) & controls (Columns 5 & Tab. S16) \\
\hline
\end{tabular}

Tab. S17. Wald tests of equality of coefficients corresponding to Tab. S16.

The Wald tests reported in this table are based on the regression analysis of Tab. S16. Wald tests are run on the null hypothesis that coefficients identifying a world religion are equal to each other across combinations of the four samples (LIQ-SP, HIQ-SP, LIQ-LP and HIQ-LP). Differences between coefficients are reported as absolute differences. $+=$ Statistical significance at the $10 \%$ level; $*=$ Statistical significance at the $5 \%$ level; $* *=$ statistical significance at the $1 \%$ level $* * *=$ statistical significance at the $0.1 \%$ level. 


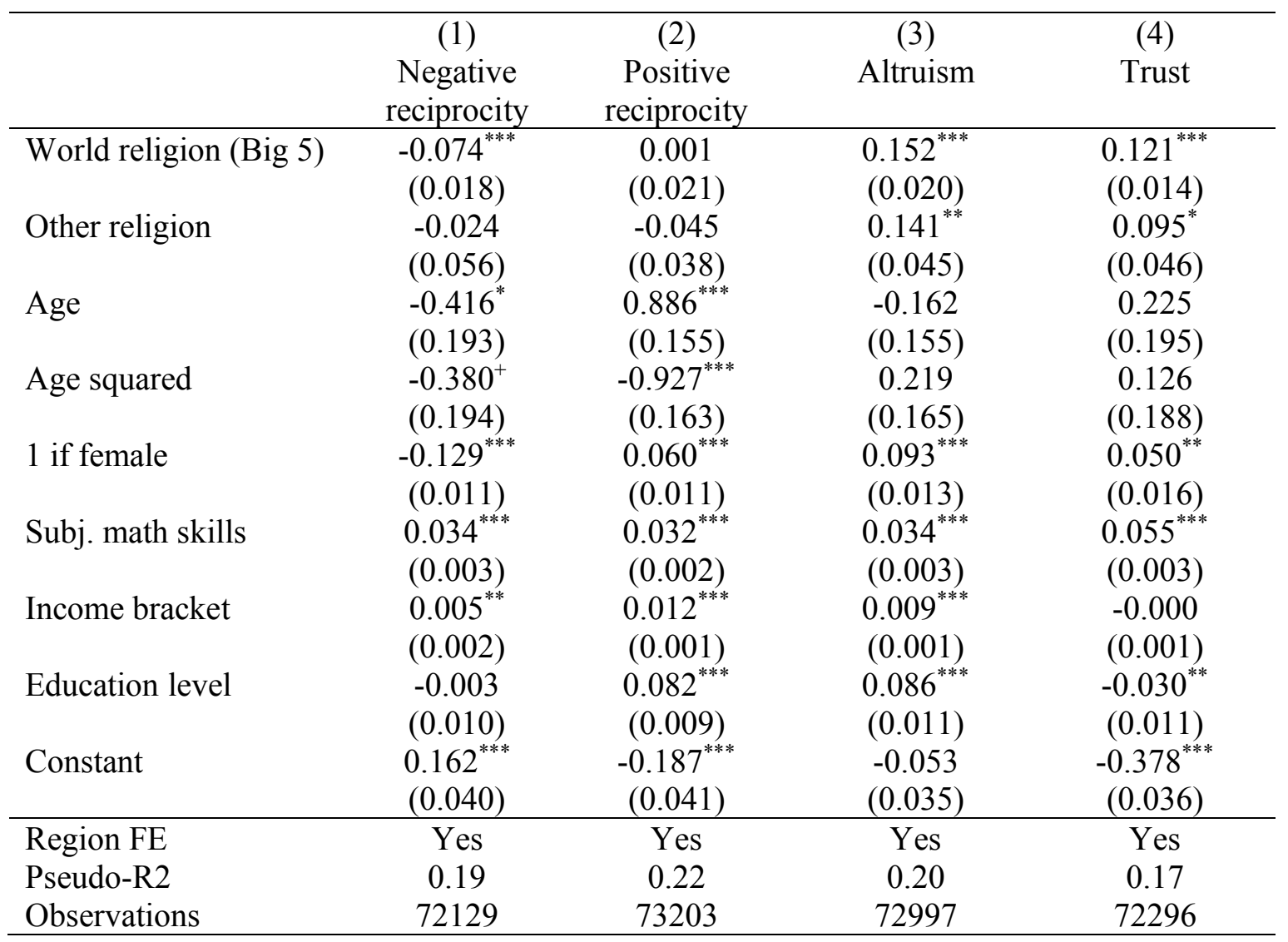

Tab. S18. Differences in social preferences between religious and non-religious people. Controlling for subnational region fixed effects.

Coefficients are based on OLS regressions. Positive values indicate that religious people exhibited higher levels of the respective preference, negative values indicate that religious people exhibited lower levels of the respective preference. The difference between members of world religions and non-religious people was calculated as the coefficient on a categorical variable that takes on the value 0 if respondent is non-religious (reference group), 1 if respondent is Christian, 2 if respondent is Muslim, 3 if respondent is Hindu, 4 if respondent is Buddhist, 5 if respondent is Jewish and 6 if respondent belongs to a non-world religion (other religion). Specifications include the following control variables: gender, age, age squared, subjective math skills, education level, household income brackets, and subnational region fixed effects. Standard errors clustered at the country level. $+=$ Statistical significance at the $10 \%$ level; $*=$ Statistical significance at the 5\% level; $* *=$ Statistical significance at the $1 \%$ level; $* * *=$ Statistical significance at the $0.1 \%$ level. 


\begin{tabular}{|c|c|c|c|c|}
\hline & $\begin{array}{c}(1) \\
\text { Sp index }\end{array}$ & $\begin{array}{l}(2) \\
2 \mathrm{PP}\end{array}$ & $\begin{array}{l}(3) \\
3 \mathrm{PP}\end{array}$ & (4) \\
\hline \multirow{2}{*}{ Christianity } & $0.146^{* * *}$ & $-0.071^{* * *}$ & $-0.052^{*}$ & $-0.081^{* * *}$ \\
\hline & $(0.024)$ & $(0.020)$ & $(0.020)$ & $(0.019)$ \\
\hline \multirow[t]{2}{*}{ Islam } & $0.196^{* * *}$ & $-0.098^{* *}$ & $-0.100^{* *}$ & $-0.111^{* *}$ \\
\hline & $(0.040)$ & $(0.031)$ & $(0.033)$ & $(0.035)$ \\
\hline \multirow[t]{2}{*}{ Hinduism } & $0.139^{* * *}$ & $-0.076^{*}$ & $-0.111^{+}$ & $-0.082^{+}$ \\
\hline & $(0.043)$ & $(0.038)$ & $(0.057)$ & $(0.041)$ \\
\hline \multirow[t]{2}{*}{ Buddhism } & $0.170^{* *}$ & -0.026 & -0.023 & -0.047 \\
\hline & $(0.053)$ & $(0.028)$ & $(0.064)$ & $(0.040)$ \\
\hline \multirow[t]{2}{*}{ Judaism } & $0.198^{* * *}$ & 0.028 & $0.243^{* * *}$ & 0.046 \\
\hline & $(0.058)$ & $(0.051)$ & $(0.052)$ & $(0.068)$ \\
\hline \multirow[t]{2}{*}{ Other religion } & $0.103^{+}$ & -0.035 & -0.006 & -0.035 \\
\hline & $(0.052)$ & $(0.050)$ & $(0.046)$ & $(0.057)$ \\
\hline \multirow[t]{2}{*}{ Age } & $0.565^{* *}$ & -0.192 & -0.092 & $-0.506^{* *}$ \\
\hline & $(0.191)$ & $(0.195)$ & $(0.172)$ & $(0.190)$ \\
\hline \multirow[t]{2}{*}{ Age squared } & $-0.403^{*}$ & $-0.546^{* *}$ & $-0.583^{* *}$ & -0.263 \\
\hline & $(0.186)$ & $(0.192)$ & $(0.174)$ & $(0.191)$ \\
\hline \multirow[t]{2}{*}{1 if female } & $0.119^{* * *}$ & $-0.111^{* * *}$ & $-0.097^{* * *}$ & $-0.130^{* * *}$ \\
\hline & $(0.017)$ & $(0.012)$ & $(0.009)$ & $(0.013)$ \\
\hline \multirow[t]{2}{*}{ Subj. math skills } & $0.066^{* * *}$ & $0.027^{* * *}$ & $0.027^{* * *}$ & $0.033^{* * *}$ \\
\hline & $(0.003)$ & $(0.003)$ & $(0.003)$ & $(0.003)$ \\
\hline \multirow[t]{2}{*}{ Income bracket } & $0.014^{* * *}$ & $0.004^{* *}$ & $0.005^{* *}$ & $0.004^{*}$ \\
\hline & $(0.002)$ & $(0.001)$ & $(0.002)$ & $(0.001)$ \\
\hline \multirow[t]{2}{*}{ Education level } & $0.096^{* * *}$ & 0.017 & $0.038^{* * *}$ & $-0.021^{*}$ \\
\hline & $(0.014)$ & $(0.012)$ & $(0.011)$ & $(0.010)$ \\
\hline \multirow[t]{2}{*}{ Constant } & $-0.361^{* * *}$ & $0.360^{* * *}$ & $-0.258^{* * *}$ & $0.420^{* * *}$ \\
\hline & $(0.055)$ & $(0.049)$ & $(0.044)$ & $(0.053)$ \\
\hline \multicolumn{5}{|c|}{ Wald test of equality of coefficients } \\
\hline \multirow[t]{2}{*}{ Christianity vs. Islam } & 0.051 & 0.027 & 0.047 & 0.030 \\
\hline & $(0.035)$ & $(0.026)$ & $(0.029)$ & $(0.031)$ \\
\hline \multirow[t]{2}{*}{ Christianity vs. Hinduism } & 0.007 & 0.005 & 0.059 & 0.001 \\
\hline & $(0.039)$ & $(0.034)$ & $(0.054)$ & $(0.039)$ \\
\hline \multirow[t]{2}{*}{ Christianity vs. Buddhism } & 0.024 & 0.045 & 0.029 & 0.033 \\
\hline & $(0.048)$ & $(0.031)$ & $(0.062)$ & $(0.046)$ \\
\hline \multirow[t]{2}{*}{ Christianity vs. Judaism } & 0.052 & $0.099^{+}$ & $0.296^{* * *}$ & $0.126^{+}$ \\
\hline & $(0.058)$ & $(0.051)$ & $(0.055)$ & $(0.070)$ \\
\hline \multirow[t]{2}{*}{ Islam vs. Hinduism } & 0.057 & 0.022 & 0.012 & 0.029 \\
\hline & $(0.035)$ & $(0.030)$ & $(0.057)$ & $(0.035)$ \\
\hline \multirow[t]{2}{*}{ Islam vs. Buddhism } & 0.027 & $0.072^{+}$ & 0.076 & 0.064 \\
\hline & $(0.052)$ & $(0.036)$ & $(0.062)$ & $(0.051)$ \\
\hline \multirow[t]{2}{*}{ Islam vs. Judaism } & 0.001 & $0.126^{*}$ & $0.343^{* * *}$ & $0.156^{*}$ \\
\hline & $(0.057)$ & $(0.052)$ & $(0.057)$ & $(0.072)$ \\
\hline \multirow[t]{2}{*}{ Hinduism vs. Buddhism } & 0.030 & 0.050 & 0.088 & 0.035 \\
\hline & $(0.051)$ & $(0.038)$ & $(0.076)$ & $(0.050)$ \\
\hline \multirow{2}{*}{ Hinduism vs. Judaism } & 0.058 & $0.104^{+}$ & $0.355^{* * *}$ & 0.128 \\
\hline & $(0.061)$ & $(0.060)$ & $(0.077)$ & $(0.079)$ \\
\hline
\end{tabular}




\begin{tabular}{lcccc} 
Buddhism vs. Judaism & 0.028 & 0.055 & $0.266^{* *}$ & 0.093 \\
& $(0.069)$ & $(0.057)$ & $(0.078)$ & $(0.080)$ \\
\hline Region FE & Yes & Yes & Yes & Yes \\
Pseudo-R2 & 0.26 & 0.14 & 0.16 & 0.18 \\
Observations & 72061 & 72182 & 72184 & 72129 \\
\hline
\end{tabular}

Tab. S19. Differences in prosocial preferences and punishment across world religions. Controlling for subnational region fixed effects.

Coefficients are based on OLS regressions (for further notes see Tab. S5 and S8). Specifications include the following control variables: gender, age, age squared, subjective math skills, education level, household income brackets, and subnational region fixed effects. The Wald tests reported at the middle of the table are run on the null hypothesis that coefficients of the categorical variable identifying a religion are equal to each other (differences between coefficients are reported as absolute differences). Standard errors clustered at the country level. $+=$ Statistical significance at the $10 \%$ level; $*=$ Statistical significance at the $5 \%$ level; $* *=$ Statistical significance at the $1 \%$ level; $* * *=$ Statistical significance at the $0.1 \%$ level. 